University of Louisville

ThinkIR: The University of Louisville's Institutional Repository

Electronic Theses and Dissertations

$5-2021$

\title{
Assessing the role of chronic arsenite exposure in disrupting the EGFR signaling axis.
}

Christine Kim

University of Louisville

Follow this and additional works at: https://ir.library.louisville.edu/etd

Part of the Environmental Health Commons, and the Toxicology Commons

\section{Recommended Citation}

Kim, Christine, "Assessing the role of chronic arsenite exposure in disrupting the EGFR signaling axis." (2021). Electronic Theses and Dissertations. Paper 3581.

https://doi.org/10.18297/etd/3581

This Doctoral Dissertation is brought to you for free and open access by ThinkIR: The University of Louisville's Institutional Repository. It has been accepted for inclusion in Electronic Theses and Dissertations by an authorized administrator of ThinkIR: The University of Louisville's Institutional Repository. This title appears here courtesy of the author, who has retained all other copyrights. For more information, please contact thinkir@louisville.edu. 


\title{
ASSESSING THE ROLE OF CHRONIC ARSENITE EXPOSURE IN DISRUPTING THE EGFR SIGNALING AXIS
}

\author{
By
}

Christine Kim

B.S., Purdue University, 2011

M.S., University of Kentucky, 2015

M.S., University of Louisville, 2018

\author{
A Dissertation \\ Submitted to the Faculty of the \\ School of Medicine of the University of Louisville \\ In Partial Fulfillment of the Requirements \\ For the Degree of \\ Doctor of Philosophy \\ In Pharmacology and Toxicology \\ Department of Pharmacology and Toxicology \\ University of Louisville \\ Louisville, KY
}

May 2021 
Copyright 2021 by Christine Kim

All Right Reserve 

ASSESSING THE ROLE OF CHRONIC ARSENITE EXPOSURE IN DISRUPTING THE EGFR SIGNALING AXIS

$$
\text { By }
$$

Christine Kim

B.A., Purdue University, 2011

M.S., University of Kentucky, 2015

M.S., University of Louisville, 2018

A Dissertation Approved on

$02 / 25 / 2021$

By the following Dissertation Committee:

\section{Brian P. Ceresa, Ph.D.}

J. Christopher States, Ph.D.

Joshua L. Hood, M.D., Ph.D.

Walter H. Watson, Ph.D.

John P. Wise, Sr. Ph.D. 


\section{ACKNOWLEDGEMENTS}

I sincerely thank my mentor, Dr. Brian Ceresa, for his support, guidance and encouragement. I would not have come this far without his persistent help through my research work and writing. I would also like to thank the Ceresa Lab members for suggestions, laughs and tears we shared together.

This dissertation is dedicated to my parents Seong Dong Kim and HyunJa Choi for their unconditional love and support in all my endeavors. They are my forever role models. I am who I am today because of their sacrifices and prayers. Thank you for always believing in me. l'd like to thank my sibling, John. I'm always thankful for having a brother like you. You're the best. 


\section{ABSTRCT \\ ASSESSING THE ROLE OF CHRONIC ARSENITE EXPOSURE IN DISRUPTING THE EGFR SIGNALING AXIS \\ Christine Kim}

February 25, 2021

Chronic arsenic exposure is a risk factor for the development of pulmonary diseases, including lung cancer, but the exact mechanism is not yet fully understood. Many previous studies have relied on acute arsenic exposure (i.e. 1-10 uM arsenic for 24 hours) to study arsenic toxicological effects. However, acute exposure does not reflect the levels or duration of arsenic associated with environmental exposure, or drinking of contaminated well water. This dissertation differentiates the effects of acute versus chronic arsenic exposures on the EGFR signaling axis and suggests possible mechanisms for chronic arsenic-induced pulmonary diseases. The EGFR is a receptor tyrosine kinase localized on the cell surface. Overexpression of the EGFR has been used as biomarkers for many different types of cancers, including lung cancer. There is a strong association between arsenic and lung cancer development, although the clear mechanism is still elusive. I hypothesized that chronic exposure of an environmentally relevant level of arsenic disrupts the EGFR signaling axis. To test this, a non-malignant human bronchial epithelial cell line (BEAS-2B) was exposed to $100 \mathrm{nM}$ arsenite for 24 weeks. I first differentiated the impact of acute versus chronic arsenic exposure on the EGFR signaling axis. Both acute and chronic arsenic exposure increased EGFR protein expression level, but only chronic exposure increased EGFR activity, increased transcription and protein levels of TGFa. Next, I assessed the functional effects of 
chronic arsenic exposure in BEAS-2B cells and measured EGFR dependency in chronic arsenic exposure-induced increased cell migratory ability, which may contribute to identifying a novel therapeutic target for arsenic-induced lung carcinogenesis. The dissertation proposes novel roles of acute and chronic arsenic on the EGFR signaling axis and potential mechanisms of chronic arsenic-induced lung diseases, such as lung cancer. It concludes that acute and chronic arsenic exposure impact the EGFR signaling axis in different mechanistic pathways, and chronic arsenic exposure increases cell migration in both EGFR-dependent and independent mechanisms. 


\section{TABLE OF CONTENTS}

PAGE

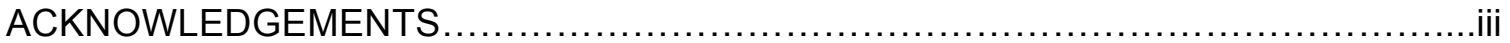

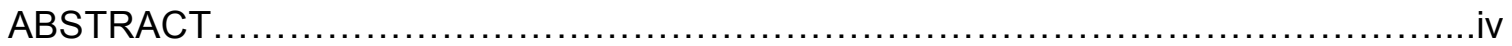

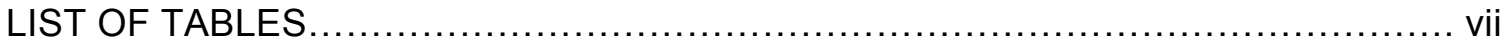

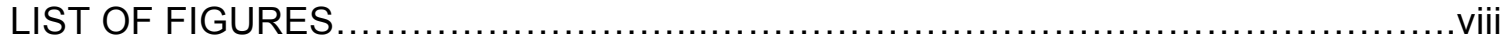

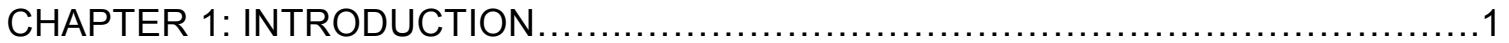

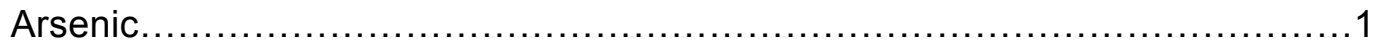

Health Effects of Acute and Chronic Arsenic Exposure.............................

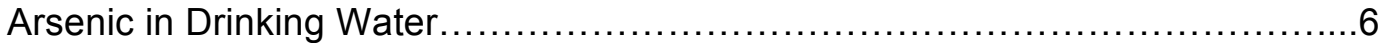

Arsenic Absorption, Distribution, Metabolism, and Excretion (ADME) .............

Arsenic and Lung cancer....................................................... 15

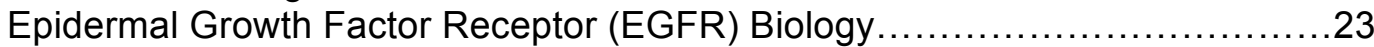

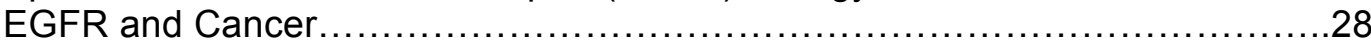

EGFR and Arsenic-induced Carcinogenesis....................................32

Significance and Specific Aims....................................................... 34

CHAPTER 2: CHRONIC AND ACUTE ARSENIC EXPOSURE IN THE EGFR

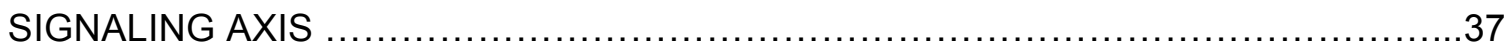

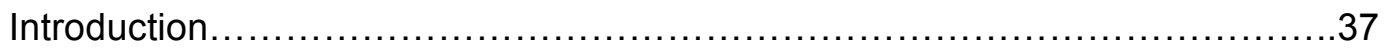

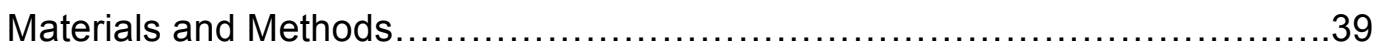

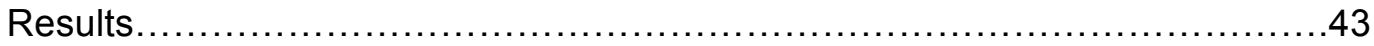

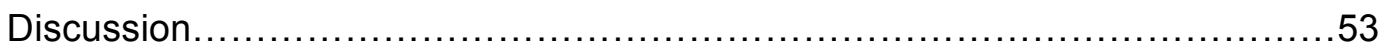

CHAPTER 3: CHRONIC ARSENIC INCREASES EGFR-DEPENDENT CELL MOTILITY

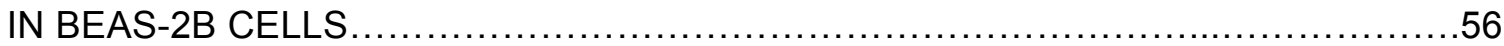

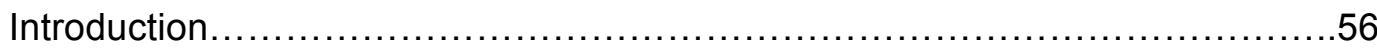

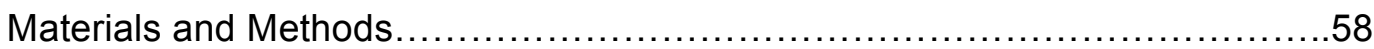

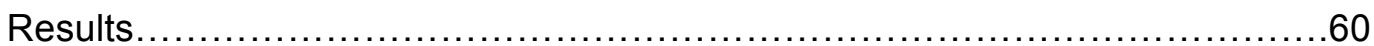

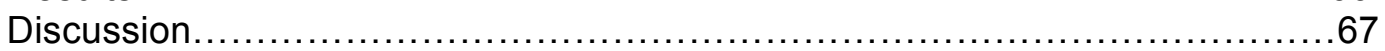

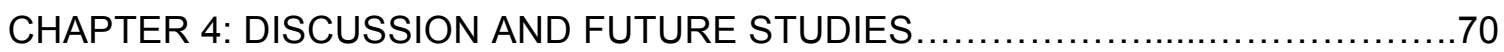

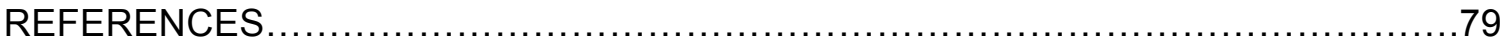

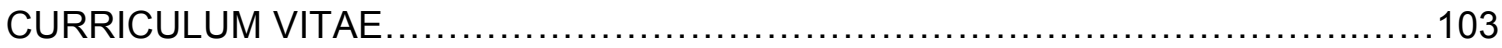




\section{LIST OF TABLES}

Table 1. Acute and chronic arsenic toxicological effects on human health $\ldots \ldots \ldots \ldots \ldots \ldots . \ldots$

Table 2: Advantages and disadvantages of in vitro and in vivo studies..................14

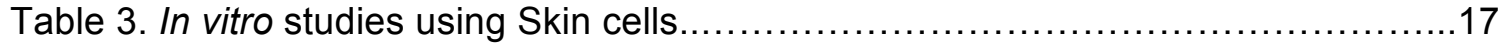

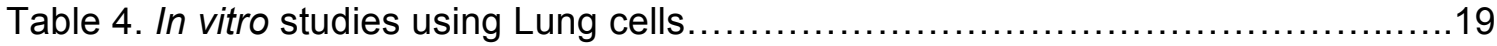




\section{LIST OF FIGURES}

FIGURE

PAGE

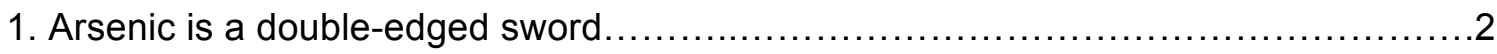

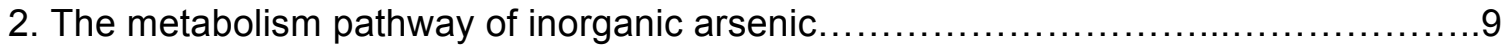

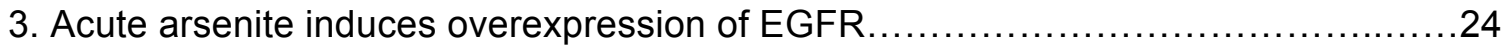

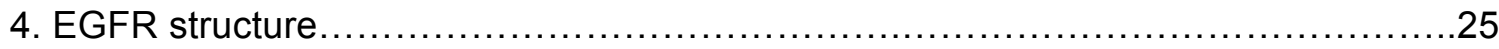

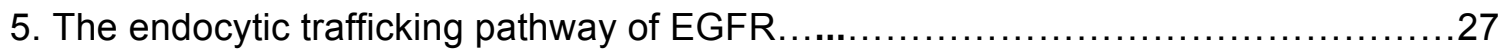

6. BEAS-2B cells exposed to acute arsenite have increased EGFR expression, altered cell morphology, and decreased viability

7. Chronic arsenite exposure induces EGFR expression and basal phosphorylation.

8. Chronic arsenite exposure increases ligand-independent cell migration.

9. Acute and chronic arsenite exposure differentially affect cell surface levels of EGFR.

10. mRNA levels of the EGFR signaling axis in response to arsenic treatment..........50

11. Chronic arsenite significantly increases TGF $\alpha$ protein levels

12. Chronic arsenic treatment of BEAS-2B cells increases basal and EGFR stimulated cell migration.

13. Chronic arsenic treatment of BEAS-2B cells increases the distance traveled and cell persistence. 62

14. EGFR is necessary and sufficient for increasing cell speed in chronic arsenic treated cells. .64 
15. EGFR is sufficient, but not necessary for increasing cell protrusion length in chronic

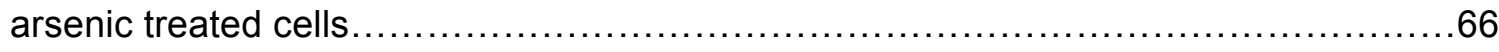
16. A schematic diagram of the impact of chronic arsenic exposure on the EGFR

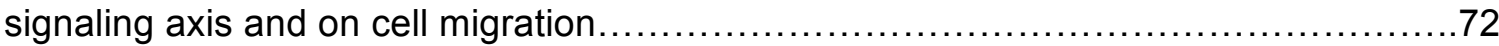




\section{CHAPTER 1}

\section{INTRODUCTION}

\section{Arsenic}

Arsenic is a powerful poison, owing to its lack of color, taste and odor [1]. It is ranked number one on the Agency for Toxic Substances and Disease Registry (ATSDR) Substance Priority List [1]. In 1973, arsenic was classified as group I "carcinogenic to humans" by the International Agency for Research on Cancer (IARC) based on epidemiological evidence in human and animal models [2-4]. Arsenic is ubiquitous in the environment, including air, soil, and water. Arsenic levels in the air and soil are difficult to measure and are not regulated by the U.S. Environmental Protection Agency (EPA) due to limited and/or transient human exposure. However, the EPA and the World Health Organization (WHO) have both set a maximum contaminant level of arsenic in drinking water to $10 \mathrm{ppb}$ [5]. Despite this guideline, there are more than 200 million people around the world routinely exposed to levels of arsenic that exceed $10 \mathrm{ppb}$ and are at risk of adverse health effects from arsenic exposure [6].

\section{i. Arsenic Uses in Medical Applications}

Arsenic is a double-edged sword, as it has been used for medical applications (Fig. 1). In the $18^{\text {th }}$ century, Thomas Fowler, an English physician, produced Fowler's Solution, a potassium bicarbonate-based arsenic solution, which was widely used to treat many conditions such as asthma, convulsions [7] and psoriasis [8]. Arsenic was also used to treat leukemia. With the Fowler's Solution, the number of white blood cells 


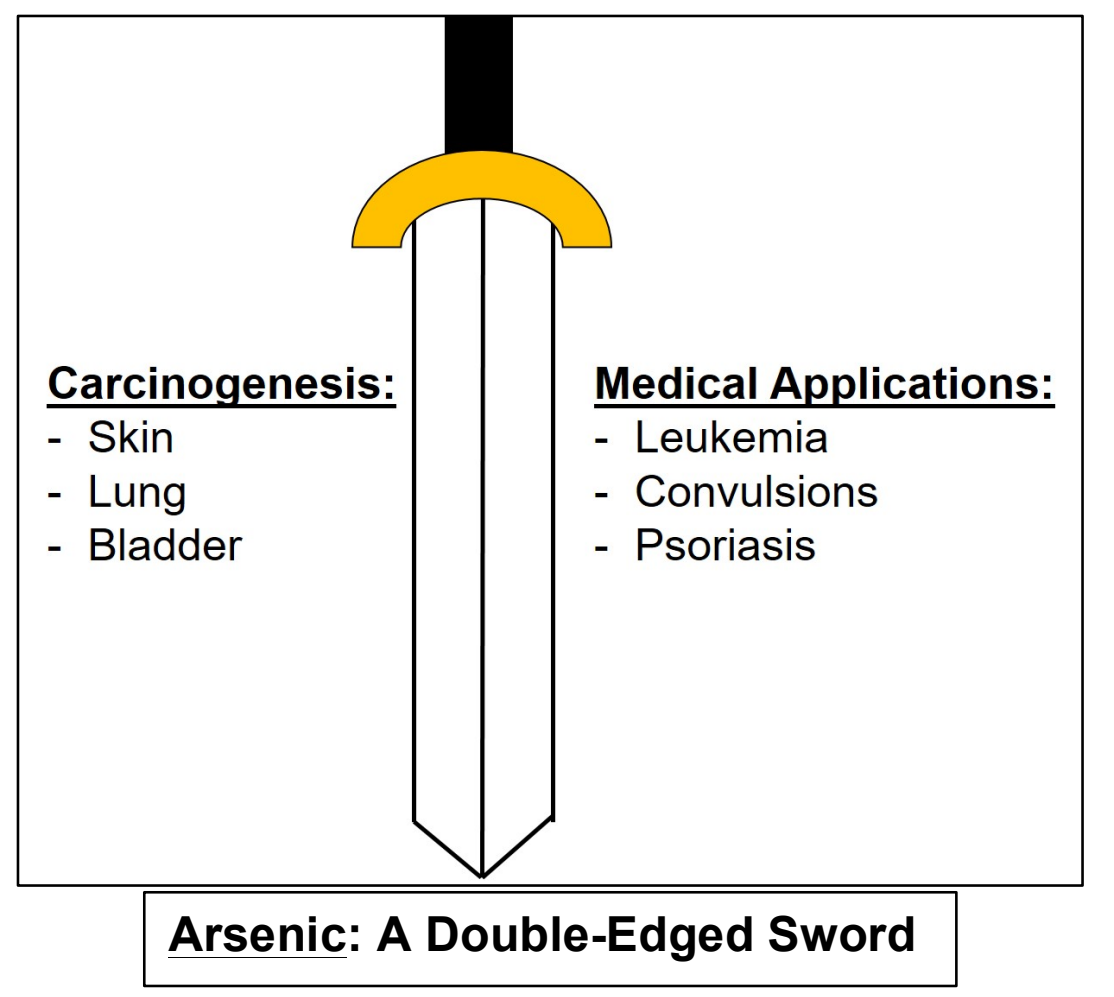

Figure 1. Arsenic is a double-edged sword.

Arsenic is now a well-established carcinogen and is prominently associated with skin, lung, and bladder cancers. Arsenic is also used in medical applications, especially as a treatment for leukemia. Despite its effectiveness, over time, carcinogenicity was observed in patients who had received arsenic treatment. Thus, its usage declined, but due to its potency in medical applications, it is under investigation for the treatment for other diseases. 
declined dramatically in leukemia patients over 10-weeks treatment period [9].

Discontinuation of the therapy, however, led to clinical relapse within few weeks.

Because of its anti-leukemic ability, arsenic was approved by the U.S. Food and Drug Administration (FDA) in 2001 for the treatment of acute promylelocytic leukemia (APL) [10], and is under investigation for the treatment of other cancer types [11-13].

Arsenic hinders repair processes of UV-induced photoadducts [14-17], and its role in repressing DNA repair processes also contributes to chemotherapeutic effect. Wang et al. showed the combination treatment of arsenic with cisplatin is more effective in treating hepatocellular carcinoma than cisplatin treatment alone [18]. Another study showed that co-treatment of arsenic with cisplatin suppressed cisplatin-induced xeroderma pigmentosum group C (XPC) expression by sensitizing wild-type p53 cells, inhibiting the repair pathway [19], which enhanced the chemotherapeutic effect. Overall, such characteristics of arsenic support its role in chemotherapy and not only human toxicity.

\section{Health Consequences of Acute and Chronic Arsenic Exposure}

The deleterious effects of arsenic are highly dependent on its dose and duration of exposure as acute and chronic toxicities present differently. According to EPA Terminology Services (TS), acute exposure is defined as an exposure for 24 hours or less, and chronic exposure is defined as an exposure lasting 6 months to a lifetime [20]. There are also subacute and subchronic exposures. Subacute exposure is an exposure between 24 hours and 28 days, and subchronic exposure is a continuous exposure up to 90 days [21].

The acute and chronic arsenic toxicological effects on human health are summarized in Table 1. The sources of acute and chronic exposure vary, as do their biological effects on the body. Usually acute toxicity results from accidental ingestion of 
high levels of arsenic, such as workers who ingest high levels of arsenic in their workplaces from dust and fumes. Ingestion of large amounts of arsenic requires treatment, such as administration of intravenous fluids, and chelation therapy to accelerate the excretion of arsenic. The symptoms include diarrhea, vomiting, dehydration, and hypotension (Table 1). In severe cases, the symptoms can lead to death, primarily due to dehydration and shock [22]. To determine the degree of acute exposure to arsenic, several tests can be performed, including blood and urine tests. The blood test, however, is useful only for 2-4 hours after initial exposure due to rapid clearance from the blood [1]. At later times, a more accurate measurement could be determined by performing a urine test. A study of individuals who ingested arsenite (a trivalent form of arsenic) containing drinking water revealed that $33 \%$ of arsenic was excreted in the urine within 48 hours, and $45 \%$ within 4 days [23].

Chronic toxicity refers to people who are exposed to low levels of arsenic over a long period of time, such as workers in construction, ore smelting, or the semiconductor industry or those that consume tainted drinking water. The skin, lungs, and liver are the main target sites, as arsenite, especially, readily interacts with thiol or sulfhydryl groups in tissue proteins of the organs [24]. The reaction between arsenic and thiol groups can alter protein conformation and function [25]. Symptoms include skin lesions, pulmonary disease, cardiovascular disease, diabetes, neurological disorders, cancer, and death (Table 1) [24, 26, 27]. Typically, epithelial cells have a high content of cysteine residues to help target proteins at the cell surface $[28,29]$. Arsenic accumulates at those locations due to its reactivity with thiol groups of cysteine residues [30, 31]. Thus, for chronic arsenic exposure, usually hair and nail analyses are reliable sources to measure the time of exposure. Further, the high thiol content of hair and nails causes the accumulation of arsenite in those tissues and makes them a reliable source for measuring cumulative arsenic levels. In individuals who have no known exposure, 


\begin{tabular}{|l|l|}
\hline Acute Exposure (<24 hours) & Chronic Exposure (>6 months) \\
\hline - Vomiting & - Cancer in many organs \\
- Diarrhea & - Cardiovascular disease \\
- Dehydration & - Respiratory disease \\
- Hypotension & - Diabetes \\
- Abdominal Pain & - Hypertension \\
- Renal Failure & - Skin lesions and pigment changes \\
& - Neurological disorders \\
\hline
\end{tabular}

Table 1. Toxicological effects of acute versus chronic arsenic exposure. 
arsenic concentrations in hair ranges from 0.02 to $0.2 \mathrm{mg} / \mathrm{kg}$ [32-38]. In areas with high concentrations of arsenic in drinking water $(>50 \mu \mathrm{g} / \mathrm{L})$, the arsenic hair level ranges from 3 to $10 \mathrm{mg} / \mathrm{kg}$ [39]. Chelation therapy can be used to mitigate chronic arsenic toxicity, but chronic arsenic exposure can cause many irreversible changes in organs and tissues. Currently, there is no known effective treatment leading to an elevated mortality rate $[40,41]$.

We observed an increased EGFR protein expression level from both acute and chronic arsenic exposure, but EGFR activity levels were significantly different depending on exposure time [42], which may suggest distinct mechanisms between acute and chronic arsenic exposure. It is not unexpected that acute and chronic toxicities result from two distinct mechanisms, because 1) different biochemical mechanisms may occur in different tissues and organs, and/or 2) different duration time of exposure at the same organ may trigger different biological responses. Therefore, depending on dose and duration of exposure, arsenic can differently affect many different types of tissues and organs causing adverse health effects [43].

\section{Arsenic in Drinking Water}

As mentioned above, due to its toxicity and the frequency of human exposure, arsenic is ranked number one on the ATSDR Substance Priority List, and its environmental contamination is a global issue. Although the Environmental Protection Agency (EPA) has set the standard for arsenic in municipal drinking water of $10 \mathrm{ppb}$ (parts per billion), which is approximately $133 \mathrm{nM}$, we are still exposed to low levels of arsenic on a daily basis. Exposure to arsenic is associated with an increased risk for a variety of health problems, such as skin and nerve damage, and cancer. More than 200 million people worldwide are chronically exposed to drinking water that is contaminated 
with arsenic that exceeds $10 \mathrm{ppb}$, the allowable limit of arsenic contaminant level in drinking water [6], and suffer from different diseases caused by drinking arseniccontaminated water. The major countries that suffer from arsenic contamination are Taiwan, Bangladesh, India, and Chile, where the arsenic concentrations in drinking water range from $40 \mu \mathrm{g} / \mathrm{L}$ to $2 \mathrm{mg} / \mathrm{L}[44,45]$, which corresponds to $532 \mathrm{nM}$ to $27 \mu \mathrm{M}$, respectively. In the United States, the maximum arsenic contaminant level in public drinking water is $10 \mathrm{ppb}$. However, approximately $15 \%$ of the U.S. population rely on private wells for their water supply that were found to have arsenic levels greater than 10 ppb [46-49]. Ingesting arsenic in naturally contaminated food and water is the most common route of arsenic exposure. Unfortunately, it is difficult to obtain an accurate measurement of the absorbed dose of arsenic in specific tissues, mainly due to variation among individuals [50], including both endogenous and exogenous factors, such as gender and occupational exposures, respectively. In 2000, Pi et al. demonstrated the average blood arsenic level in people who were exposed to high levels of arsenic in their drinking water approximately for 18 years to be about $100 \mathrm{nM}$ [51], which is the concentration that we used in this dissertation and from this point forward referred to as an 'environmentally relevant level' of arsenic. The lethal human adult dose for ingested arsenic is about $600 \mu \mathrm{g} / \mathrm{kg} /$ day [1], which is about 60 times higher than the standard set by the EPA.

\section{Arsenic Absorption, Distribution, Metabolism, and Excretion (ADME)}

Ingestion is the main route of environmental arsenic exposure, and arsenic is readily absorbed from the gastrointestinal-tract ( $\mathrm{GI}$ tract). The liver is the main site of arsenic metabolism, and historically, methylation steps have been characterized as a critical arsenic metabolism process (Fig. 2). This arsenic methylation process was initially studied by Frederick Challenger and his colleagues in the $19^{\text {th }}$ century $[52,53]$. 
When arsenate (pentavalent arsenic) enters the cells, it gets rapidly reduced by arsenate reductase to arsenite (trivalent arsenic) [54, 55]. Arsenite, then gets methylated by arsenic (III) methyltransferase (AS3MT) as it attaches a methyl group. AS3MT uses Sadenosylmethione (SAM) as the methyl donor to generate the metabolites [56]. Arsenic metabolites including monomethylarsonous acid $\left(\mathrm{MMA}^{\mathrm{III}}\right)$, monomethylarsonic acid $\left(\mathrm{MMA}^{\vee}\right)$, dimethylarsinic acid $\left(\mathrm{DMA}^{\mathrm{III}}\right)$, and dimethylarsenic acid $\left(D M A^{\vee}\right)$ are produced (Fig. 2).

There is an alternative model for arsenic methylation that has been proposed by Hayakawa et al. that suggests glutathione (GSH) serves as a chaperone during the methylation step and the products are trivalent arsenic species [57]. Nonetheless, it is important to highlight that humans convert inorganic pentavalent arsenic to MMA species, and further into DMA species. Though both pentavalent and trivalent forms of arsenic are environmentally relevant, pentavalent arsenic is not readily taken into cells, unless the cells are phosphate deprived, as it requires phosphate transporters to enter the cells [58]. However, trivalent arsenic is taken into cells much faster than pentavalent, as it is imported by aquaporins [58], which can explain lower rate of accumulation of pentavalent arsenic species [59-61]. This further suggests higher potency of trivalent arsenic over pentavalent.

The relative distribution of arsenic metabolites in the urine varies among population groups, which suggests genetic polymorphism of human methyltransferases [62-64], which can then increase the disease susceptibility in people. A study that was done in northern Argentina has shown polymorphisms of AS3MT influencing its activity, resulting in variation in the urinary arsenic metabolites as the women in northern Argentina had a higher ratio of DMA/MMA [65], which reflects better clearance of arsenic from the body, increasing arsenic tolerance [66]. Similarly, another study from Chile has shown four polymorphisms of AS3MT that are associated with more efficient arsenic 


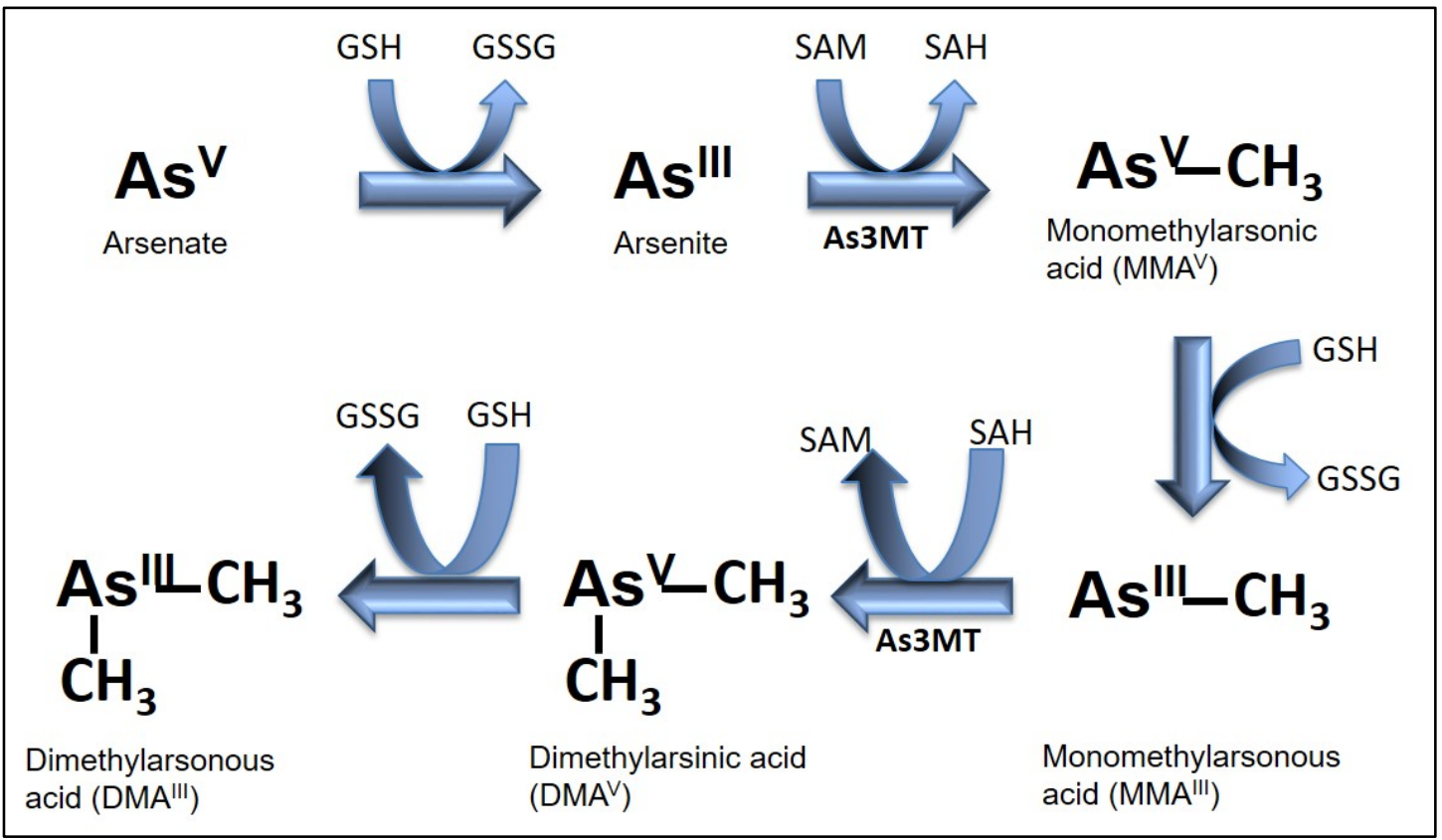

Figure 2. The metabolism pathway of inorganic arsenic.

The metabolism pathway of arsenate undergoing reduction and methylation to produce metabolites in pentavalent and trivalent forms. The products of inorganic arsenic metabolism include $\mathrm{MMA}^{\mathrm{III}}, \mathrm{MMA}^{\mathrm{V}}, \mathrm{DMA}^{\mathrm{III}}$ and $\mathrm{DMA}^{\mathrm{V}}$. Unlike humans, rats can undergo another round of methylation from $\mathrm{DMA}^{\mathrm{III}}$ to trimethylarsine oxide (TMAO or TMA ${ }^{\mathrm{V}}$ ). 
metabolism [67]. However, there are other polymorphisms of AS3MT resulting in a higher urinary MMA/DMA ratio that is associated with arsenic-related diseases, such as cancer [66]. Because the methylation process is important in elimination of arsenic from the systemic circulation, it is easy to assume that methylation is a detoxification process of arsenic as it enhances excretion of arsenic from the systemic circulation. However, all arsenic metabolites are toxic to different degrees. For example, DMA ${ }^{\mathrm{V}}, \mathrm{MMA}^{\mathrm{III}}$ and $D_{M M}{ }^{I I I}$ are observed to be more cytotoxic and genotoxic than arsenite $[59,60,68,69]$. Thus, arsenical metabolites are not just the by-products of inorganic arsenic metabolism; they, too, exert toxic effects.

\section{Target Organs}

Skin

The skin is the major target organ of arsenic and usually the first manifestation of arsenic toxicity [70]. There is a strong association between arsenic exposure and dermatological effects, including blackfoot disease, hyperkeratosis and hyperpigmentation $[71,72]$. Several in vitro studies support the epidemiological studies as shown in Table 3.

\section{Lung}

There is strong evidence that shows association between arsenic and respiratory illness, such as bronchitis. Though arsenic can cause non-cancer diseases, non-small cell lung cancer is a common consequence from arsenic exposure, especially from chronic arsenic exposure. A study by Smith et al. has shown that early life exposure to arsenic can lead to pulmonary diseases in adulthood, such as lung cancer, highlighting the late effects of early life arsenic exposure [73]. Several studies have shown malignant transformation and epithelial-mesenchymal-transition (EMT) in lung cells from chronic arsenic exposure shown in Table 4, as well as in in vivo studies [74-78]. Based on 
epidemiological studies, countries, such as Inner Mongolia and Argentina observed a positive association between arsenic exposure and lung cancer in both sexes [79, 80].

Heart

There is evidence that show strong association between arsenic exposure and development of cardiovascular and coronary artery diseases. Many studies suggest arsenic-induced oxidative stress, inflammation, endoplasmic reticulum stress and unfolded protein responses play roles in development of cardiovascular diseases [81]. Consistently, mice exposed to arsenic for 24 weeks developed lesion formation in the aorta [82]. However, many of these studies are established by using high doses ( $>5$ $\mathrm{mg} / \mathrm{L})$ of arsenic exposure $[82,83]$. Most of affected populations worldwide suffer from chronic exposure of low to moderate level of arsenic and whether low level of arsenic exposure leads to cardiovascular diseases still remains inconclusive [81, 84].

Liver

As the liver is the main site of arsenic metabolism, it is one of the major target organs of arsenic. There is evidence that chronic arsenic exposure causes epigenetic changes in the liver that can induce liver disease by increasing inflammatory responses [81]. Interestingly, inflammation is an important factor that contributes to cardiovascular disease as well, thus there is evidence that endothelial dysfunction can be caused by indirect effects on the liver caused by arsenic-induced inflammation. Further, a study has shown increased serum levels of liver injury biomarkers can be used to measure cardiovascular risk as well [85], suggesting a link between liver disease and cardiovascular disease. Chronic arsenic exposure is also known to cause liver cancer, but the mechanism still remains elusive. There are several proposed mechanisms, including oxidative DNA damage [86-89], impaired DNA repair [90, 91], apoptotic tolerance [92], and epigenetic modulation [93-96]. 


\section{Models for studying Arsenic Toxicity}

Many epidemiological studies show adverse effects from arsenic exposure, including carcinogenesis in humans. However, the mechanism by which arsenic induces cancer development is still unclear. To elucidate the mechanism and its targets, both in vitro and in vivo models are widely used.

\section{Rodent models of arsenic toxicity}

Rodent models of arsenic toxicity are frequently used, as the target sites of arsenic carcinogenic effects in rodents are concordant with most of the human targets of arsenic [97]. However using animal models to understand the mode of action for inorganic arsenic-induced carcinogenesis still remains controversial [98]. The controversy is due to different ADME of arsenic between rodents and humans. Unlike humans, rats can metabolize further to trimethylarsine oxide $\left(\mathrm{TMA}^{\vee}\right)$ [99], rendering rodents to be less sensitive to arsenic toxicity due to rapid clearance [22]. Not only species, but also strain differences in rodents, also alter sensitivity to arsenic [100].

Despite the limitations, the rodent models are widely used and known to reflect human toxicological responses. Studies have observed tumorigenesis in mice exposed to arsenic in multiple target organs, including lungs [75], which is consistent with epidemiological studies [101-107]. Animal studies are also useful in understanding the magnitude of toxicity of arsenic species, as different forms of arsenic species have preferential target organs. GI tract and kidneys appear to be sensitive target organs for MMA, whereas bladder and kidneys are the sensitive target organs for DMA [1]. Further, non-cancer diseases can arise from chronic exposure to low levels of arsenic. Based on epidemiological studies, the majority of non-cancer disease burden and mortality from low level of chronic arsenic exposure is cardiovascular disease and coronary artery 
disease [108-111], which is consistent with the animal studies [112]. These studies suggest that animal studies are useful in assessing adverse effects of arsenic and its relevance to human exposure. However, it is important to recognize that the pharmacokinetics of arsenic in rodent models limit our understanding of the pharmacodynamics of arsenic exposure in humans.

In vitro models of arsenic toxicity

In vitro models have become a crucial tool for understanding the molecular mechanisms underlying arsenic toxicity and carcinogenesis. By using tissue culture models, we can more specifically define and refine experimental conditions and ultimately perform more focused in vivo experiments and epidemiological studies. In vitro models include 2D (two-dimensional) systems, which use cells grown in a single layer, and 3D (three-dimensional) systems, that grow cells on a matrix or in suspension, to mimic the in vivo architecture, better representing in vivo scenario. Nonetheless, both in vitro models are reproducible and cost effective, serving as a platform for more in vivo experimental models. However, since in vitro models are static systems and look at cells in isolation, they do not simulate the real body condition. Thus, ultimately, animal models and epidemiological studies are needed to determine if predictions are physiologically relevant. The advantages and disadvantages of in vitro and in vivo studies are summarized in Table 2.

\section{Arsenic and Lung Cancer}

\section{i. Arsenic in Drinking Water and Lung Cancer Development}

A common type of cancer in the U.S. that is induced by chronic exposure of arsenic is lung cancer [113-115]. The two major forms of lung cancer are non-small cell lung carcinoma (NSCLC), and small cell lung carcinoma (SCLC). NSCLC accounts for 
Table 2: Advantages and disadvantages of in vitro and in vivo studies.

\begin{tabular}{|c|c|c|c|}
\hline & Primary Cells & Immortalized Cells & In vivo animal models \\
\hline Advantages & $\begin{array}{l}\text { - Genetically stable } \\
\text { - Physiologically relevant to in } \\
\text { vivo }\end{array}$ & $\begin{array}{l}\text { - Rapid } \\
\text { - Cost effective } \\
\text { - Repeatable } \\
\text { - Not limited lifespan }\end{array}$ & $\begin{array}{l}\text { - Relevant to effects on } \\
\text { human } \\
\text { - Study of complex } \\
\text { interactions }\end{array}$ \\
\hline Disadvantages & $\begin{array}{l}\text { - Limited lifespan } \\
\text { - Limited proliferative capacity } \\
\text { - More expensive than } \\
\text { immortalized cell culture } \\
\text {-Sensitive and easy to get } \\
\text { contaminated }\end{array}$ & $\begin{array}{l}\text { - Multiple changes upon } \\
\text { immortalization } \\
\text { - Difficult to extend results } \\
\text { to a whole organism }\end{array}$ & $\begin{array}{l}\text { - Expensive } \\
\text { - Time consuming } \\
\text { - Ethical concerns } \\
\text { - Difficult to control due } \\
\text { to variables }\end{array}$ \\
\hline
\end{tabular}


more than $80 \%$ of all lung cancer. NSCLC can be divided into three major histological subtypes: squamous-cell carcinoma, adenocarcinoma, and large-cell lung cancer. Adenocarcinoma is the most common type of lung cancer in patients who have never smoked. Squamous-cell carcinoma is also frequently observed in non-smokers, and is highly associated with chronic exposure to arsenic $[102,103]$. Previous studies reveal a direct correlation between arsenic in drinking water and cancer development [45, 80, $102,103,114,116-128]$. To investigate a direct environmental factor that is associated with lung cancer development in individuals who have never smoked, Putila and Guo identified a positive correlation between arsenic levels and lung cancer incidence [114]. This study underscored the association between arsenic and lung cancer, independent of smoking and socioeconomic status in the United States [114]. Particularly, people who reside in the Appalachian portion of Kentucky have a higher incidence of lung cancer due to coal mining in Appalachia [129], as arsenic is naturally found in rocks and coal. This direct relationship between arsenic and lung cancer was also observed in countries that have high levels of arsenic in drinking water that can range up to $300 \mu \mathrm{g} / \mathrm{L}$, which approximately corresponds to $4 \mu \mathrm{M}$, and these countries had some of the highest incidences of lung cancer in the world [123, 128, 130-132]. In Bangladesh, 1 in 16 cancer deaths are attributable to arsenic exposure in drinking water [133].

\section{ii. Early Life Exposure to Arsenic and Lung Cancer}

Not only post-natal arsenic exposure, but also pre-natal arsenic exposure can lead to lung cancer as well. As pre-natal stage is a critical period of development, young children in Chile, who had in utero-only and/or early-life arsenic exposure concentrations nearly up to $1,000 \mu \mathrm{g} / \mathrm{L}$, developed lung cancer [73]. Consistently, when pregnant mice received $85 \mathrm{ppm}$ arsenic-contaminated water only during pregnancy (gestation days 8 to 18), the offspring had lung tumor formation in adulthood [134]. These studies highlight 
the lethality of pre-natal exposure to arsenic, as the placenta cannot serve as a barrier to arsenic. A study compared the cancer progression in mice with whole-life $24 \mathrm{ppm}$ arsenic exposure (exposure before and after birth and termination months before a full life span [135]) and in utero-only 85 ppm arsenic exposure (gestation days 8 to 18), and observed development of lung adenocarcinoma and hepatocellular carcinoma in both groups of mice with whole-life and in utero-only exposure [136]. However, there were higher incidences of cancer development in offspring that had whole-life arsenic exposure. These results suggest whole-life arsenic exposure can aggravate the tumor progression $[75,137,138]$.

\section{iii. Effects of Acute and Chronic Arsenic in skin and lungs in in vitro models}

As skin and lungs are the two major target organs of arsenic exposure shown by previous human and animal studies [2-4, 75], several research studies have used these epithelial cell lines for the in vitro analysis of arsenic effects. The most commonly used cell lines are $\mathrm{HaCaT}$ and BEAS-2B cells, which are immortalized human keratinocytes, and bronchial epithelial cells, respectively. Although studies have reported that they are non-malignant $[139,140]$, their immortality raises concerns for scientists who utilize these cell lines to mimic human exposure to arsenic. Thus, there are several studies that have used primary or patient-derived cell lines to exhibit normal human physiology and biochemistry. However, these cell lines are a challenge in studying chronic arsenic exposure due to their limited lifespan. A compilation of these in vitro studies [Tables 3 (skin) and 4 (lung)] allows us to analyze the findings from studies utilizing a variety of cell lines, arsenic concentrations and exposure times. The variations in arsenic concentrations make direct comparisons challenging; however, the majority of these studies reflect the differences in the level of arsenic exposure across the globe. 
Table 3: In vitro studies using Skin cells.

\begin{tabular}{|c|c|c|c|c|c|c|}
\hline & Cell line & Arsenic [ ] & Duration & Transformed? & Cell biology & Ref. \\
\hline \multirow[t]{10}{*}{ Acute } & NHEK & $\begin{array}{l}0.001-0.005 \\
\mu \mathrm{M} \text { and } 0.1-4 \\
\mu \mathrm{M}\end{array}$ & $<18 \mathrm{~h}$ & N/D & $\begin{array}{l}\text { 个 Cell proliferation } \\
\text { 个GM-CSF, TGFa, and TGF } \beta \text { mRNA }\end{array}$ & [141] \\
\hline & NHK & $0.001-5 \mu \mathrm{M}$ & $24 \mathrm{~h}$ & N/D & $\begin{array}{l}\text { 个 Cell proliferation } \\
\uparrow \text { p53 expression, p53 binding to DNA } \\
\text { Activation of PI3K/PKB/GSK3 } \beta \text { pathway }\end{array}$ & {$[142]$} \\
\hline & $\mathrm{HaCaT}$ & $0.5,2,10 \mu \mathrm{M}$ & $24 \mathrm{~h}$ & N/D & $\uparrow$ AIM2 protein expression & [143] \\
\hline & HaCaT & 4 and $8 \mu \mathrm{M}$ & $<24 h$ & N/D & $\uparrow$ Protein and mRNA levels of p62 & [144] \\
\hline & HaCaT & $50 \mu \mathrm{M}$ & $24 \mathrm{~h}$ & N/D & 个 CD34 expression & [145] \\
\hline & HaCaT & $\begin{array}{l}2.5,5,10,20 \\
\mu \mathrm{M}\end{array}$ & $24 \mathrm{~h}$ & N/D & $\begin{array}{l}\downarrow \text { XPA, XPD and XPF gene expressions, } \\
\text { H3K18ac } \\
\text { DNA damage }\end{array}$ & [146] \\
\hline & HaCaT & $\begin{array}{l}0.05,0,1,0.5 \\
1,5 \mu \mathrm{M}\end{array}$ & $24 \mathrm{~h}$ & N/D & $\begin{array}{l}\text { Changes in hydrogen peroxide, } 8-\mathrm{OHdG} \text {, } \\
\text { MDA, and superoxide levels }\end{array}$ & [147] \\
\hline & HaCaT & $\begin{array}{l}5,10,20,30 \\
4060 \mu \mathrm{M}\end{array}$ & $<24 \mathrm{~h}$ & N/D & $\begin{array}{l}\text { NRF1 overexpression reduces arsenic- } \\
\text { induced cytotoxicity and apoptosis }\end{array}$ & [148] \\
\hline & HaCaT & $\begin{array}{l}2.5,5,10,20 \\
\mu \mathrm{M}\end{array}$ & $24 \mathrm{~h}$ & $\mathrm{~N} / \mathrm{D}$ & $\begin{array}{l}\downarrow \times P A, X P D, \text { and XPF gene expression } \\
\text { levels, H3K18ac modification } \\
\text { Induces DNA damage }\end{array}$ & [149] \\
\hline & HaCaT & $0-40 \mu \mathrm{M}$ & $24 \mathrm{~h}$ & N/D & $\begin{array}{l}\text { Low dose, generation of ROS, } \uparrow \text { cell } \\
\text { survival and } \mathrm{m}^{6} \mathrm{~A} \text { and methyltransferases } \\
\text { High dose, } \uparrow \text { cytotoxicity, oxidative stress, } \\
\text { cell death, } \downarrow \mathrm{m}^{6} \mathrm{~A} \text { and methyltransferases }\end{array}$ & {$[150]$} \\
\hline \multirow[t]{13}{*}{$\begin{array}{l}\text { Subacute/ } \\
\text { Subchronic }\end{array}$} & HaCaT & $2.5 \mathrm{uM}$ & $8 w$ & Yes & $\begin{array}{l}\text { PI3K/AKT pathway-dependent Cyclin D1 } \\
\text { expression }\end{array}$ & [151] \\
\hline & HaCaT & $0.6 \mu \mathrm{M}$ & $18 w$ & Yes & $\begin{array}{l}\text { 个 Colony formation and growth rate } \\
\uparrow \text { CD44v6 expression } \\
\uparrow \text { G2/M and S phases } \\
\uparrow \text { Activating NFkB and p53 genes }\end{array}$ & [152] \\
\hline & HaCaT & $500 \mathrm{nM}$ & $4 w$ & N/D & 个 miRNA 21, 200a and 141 & [153] \\
\hline & HaCaT & $1 \mu \mathrm{M}$ & $15 w$ & Yes & $\begin{array}{l}\downarrow \text { let-7 } \\
\text { Activation of Ras/NFkB signaling pathway }\end{array}$ & [154] \\
\hline & HaCaT & $0.5,2,10 \mu \mathrm{M}$ & $\begin{array}{l}48 \text { and } \\
72 h\end{array}$ & N/D & $\begin{array}{l}\text { At low concentration- } \uparrow \text { colony formation } \\
\text { and proliferation } \\
\text { At high concentration- } \downarrow \text { cell viability, } \uparrow \\
\text { cleaved caspase-1 and AIM2 } \\
\text { inflammasome }\end{array}$ & [143] \\
\hline & HaCaT & $100 \mathrm{nM}$ & 3 and $7 w$ & N/D & $\begin{array}{l}\text { Arsenite-dependent small RNA and mRNA } \\
\text { differential expression }\end{array}$ & [155] \\
\hline & HaCaT & $100 \mathrm{nM}$ & $7 w$ & N/D & $\begin{array}{l}\text { 个 G2/M phase } \\
644 \text { miRNA differentially expressed }\end{array}$ & [156] \\
\hline & HaCaT & $0.6 \mu \mathrm{M}$ & $8 w$ & N/D & ^ miRNA 21, PTEN, PCDC4 & [157] \\
\hline & HaCaT & $\begin{array}{l}0.05 \text { and } 0,1 \\
\mu \mathrm{M}\end{array}$ & $15 w$ & N/D & $\begin{array}{l}\text { ^ Cell proliferation and cell cycle } \\
\text { progression from } \mathrm{G} 1 \text { to } \mathrm{G} 2 / \mathrm{M} \text { phase } \\
\uparrow \text { Total Cyclin D1, p-AKT, p-GSK-3b, p- } \\
\text { p21, p-p27 } \\
\downarrow \text { p-Cyclin D1, p21, p27 }\end{array}$ & [158] \\
\hline & HaCaT & $\begin{array}{l}0.1 \text { and } 0.2 \\
\mu \mathrm{M}\end{array}$ & $<4 w$ & Yes & $\begin{array}{l}\text { 个 Cell proliferation and TGIF expression, } \\
\text { invasion } \\
\text { EMT transition markers alteration, MMP } \\
\text { activation, invadopodia formation. }\end{array}$ & [159] \\
\hline & HaCaT & $100 \mathrm{nM}$ & $8 w$ & N/D & $\begin{array}{l}\text { 个 Structural abnormalities in cells } \\
\text { overexpressing has-miRNA } 186 . \\
\uparrow \text { BUB1 expression }\end{array}$ & [160] \\
\hline & HaCaT & $5 \mu \mathrm{M}$ & $<72 \mathrm{~h}$ & N/D & $\begin{array}{l}\text { ^ ZRANB2 expression } \\
\text { ZRANB2-directed TRA2B splicing impaired } \\
\text { Arsenite displaces } \mathrm{Zn}^{2+} \text { from ZRANB2 zfms }\end{array}$ & [161] \\
\hline & HaCaT & $1 \mu \mathrm{M}$ & $12 w$ & N/D & $\begin{array}{l}\uparrow \text { p62, Nrf2, HO-1 and SOD expression } \\
\text { levels } \\
\downarrow \text { Autophagy by up-regulating mTOR }\end{array}$ & [162] \\
\hline
\end{tabular}




\begin{tabular}{|c|c|c|c|c|c|c|}
\hline & & & & & $\begin{array}{l}\text { Activation of PI3K/Akt/mTOR pathway, } \\
\text { induced autophagy deficiency, changes in } \\
\text { intracellular hydrogen peroxide, superoxide, } \\
\text { MDA and 4-HNE }\end{array}$ & \\
\hline & HaCaT & $1 \mu \mathrm{M}$ & $20 w$ & Yes & $\begin{array}{l}\uparrow \mathrm{m}^{6} \mathrm{~A} \text { level } \\
\mathrm{m}^{6} \mathrm{~A} \text { mediates migration and apoptosis and } \\
\text { attenuates p53 activation to mediate } \\
\text { arsenic- induced transformation }\end{array}$ & [163] \\
\hline & $\mathrm{HaCaT}$ & $0.05,0.1 \mu \mathrm{M}$ & $15 w$ & $\mathrm{~N} / \mathrm{D}$ & 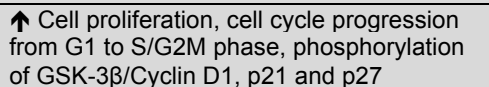 & [158] \\
\hline & HaCaT & $1 \mu \mathrm{M}$ & $20 w$ & Yes & $\begin{array}{l}\text { 个 circLRP6 and ZEB1 levels } \\
\text { Induces the EMT }\end{array}$ & [164] \\
\hline \multirow[t]{6}{*}{ Chronic } & HaCaT & $100 \mathrm{nM}$ & $28 w$ & Yes & $\begin{array}{l}\text { Morphology changes } \\
\text { Resistant to UVB-induced apoptosis } \\
\text { ^ Active MMP-9, keratin-1, 10, involucrin, } \\
\text { loricrin } \\
\text { ^ CK2 expression and nuclear activity } \\
\uparrow \text { Antioxidant level } \\
\Downarrow \text { Nrf2-mediated antioxidant response }\end{array}$ & [165] \\
\hline & HaCaT & $100 \mathrm{nM}$ & $>25 w$ & Yes & $\begin{array}{l}\text { 个 MMP-9 secretion } \\
\text { T CK1, 10,13,5, 8, 14, } 18 \text { and } 15, \\
\text { involucrin and loricrin }\end{array}$ & [166] \\
\hline & HaCaT & $100 \mathrm{nM}$ & $28 w$ & Yes & 26 miRNAs significantly altered & [167] \\
\hline & HaCaT & $100 \mathrm{nM}$ & $40 w$ & Yes & $\begin{array}{l}\text { 个 Expression of TLR4, CD34, CXCR4, } \\
\text { MMP2 } \\
\uparrow \text { invasion }\end{array}$ & [168] \\
\hline & HaCaT & $100 \mathrm{nM}$ & $30 w$ & Yes & $\begin{array}{l}\text { 个 p62 expression, p62-NRF2 feedback } \\
\text { loop } \\
\text { Dysregulated autophagy }\end{array}$ & [169] \\
\hline & HaCaT & $100 \mathrm{nM}$ & $25 w$ & Yes & $\begin{array}{l}\text { Progressive aberrant DNA methylation, } \\
\text { alteration of methylation-expression } \\
\text { landscape }\end{array}$ & [170] \\
\hline
\end{tabular}

* The original study used in $\mathrm{ppb}$

Duration in hours (h), days (d), and weeks (w)

GM-CSF: Granulocyte-macrophage colony-stimulating factor; TGFa: Transforming growth factor alpha; TGF $\beta$ : Transforming growth factor beta; PI3K: Phosphoinositide 3-kinase; PKB: Protein kinase B (also known as Akt); AIM2: Absent in melanoma 2; CD34: XPA: Xeroderma pigmentosum complementation group A; XPD: Xeroderma pigmentosum complementation group D; XPF: Xeroderma pigementosum complementation group F; H3K18ac: Histone 3 Lysine 18 acetylation; NFkB: Nuclear factor kappa-light-chain-enhancer of activated B cells); let-7: Lethal-7; GSK-3ß: Glycogen synthase kinase 3 beta; BUB1: Budding uninhibited by benzimidazoles 1; ZRANB2: Zinc finger RANBP2-type containing 2; TRA2B: Transformer 2 beta; UVB: Ultraviolet B; MMP: Matrix metallopeptidase; CK: Creatine kinase; Nrf2: Nuclear factor erythroid 2-related factor 2; TLR4: Toll ligand receptor 4; CXCR4: C-X-C motif chemokine receptor 4; 
Table 4: In vitro studies using Lung cells.

\begin{tabular}{|c|c|c|c|c|c|c|}
\hline & Cell line & Arsenic [ ] & Duration & Transformed? & Cell biology & Ref. \\
\hline \multirow[t]{10}{*}{ Acute } & 16HBE140- & $0.2-3.8 \mu \mathrm{M}^{*}$ & $<24 h$ & $N / D$ & $\begin{array}{l}\downarrow \text { Wound repair } \\
\uparrow \text { MMP9 mRNA and protein expression } \\
\text { levels as well as activity }\end{array}$ & [171] \\
\hline & BEAS-2B & $0.01-10 \mu \mathrm{M}$ & $<5 h$ & N/D & $\begin{array}{l}\text { 个 EGFR activity, Hb-EGF mRNA level, p- } \\
\text { ERK and cyclin D1 expression }\end{array}$ & [172] \\
\hline & BEAS-2B & $1 \mu \mathrm{M}$ & $24 \mathrm{~h}$ & N/D & $\begin{array}{l}\text { 个 miRNA } 21 \text { expression } \\
\text { Activation of STAT3 }\end{array}$ & [173] \\
\hline & $\mathrm{HBE}$ & $\begin{array}{l}0.5,1,2,5 \\
10 \mu \mathrm{M}\end{array}$ & $24 \mathrm{~h}$ & $\mathrm{~N} / \mathrm{D}$ & 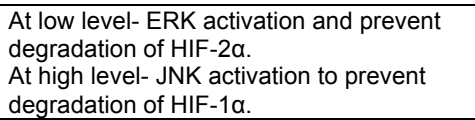 & [174] \\
\hline & BEAS-2B & $0.5,1,2 \mu \mathrm{M}$ & $24 \mathrm{~h}$ & N/D & $\downarrow$ miRNA 199a expression & [175] \\
\hline & BEAS-2B & $1 \mu \mathrm{M}$ & $24 \mathrm{~h}$ & N/D & $\begin{array}{l}\Downarrow \text { PDCD4 } \\
\uparrow \text { Twist } 1 \text { expression }\end{array}$ & [176] \\
\hline & BEAS-2B & $0.25 \mu \mathrm{M}$ & $24 \mathrm{~h}$ & N/D & 个 IL6, IL8, TNFa and GM-CSF production & [177] \\
\hline & $\mathrm{HBE}$ & $1-60 \mu \mathrm{M}$ & $<24 h$ & N/D & $\begin{array}{l}\downarrow \text { cell viability } \\
\uparrow \text { Nrf2 signaling pathway } \\
\text { Oxidative damage }\end{array}$ & [178] \\
\hline & $\mathrm{HBE}$ & $1-60 \mu \mathrm{M}$ & $<24 h$ & $\mathrm{~N} / \mathrm{D}$ & $\begin{array}{l}\downarrow \mathrm{Ca}^{2+} \text { homeostasis of ER } \\
\text { Apoptosis through mitochondrial } \\
\text { dysfunction, nuclear translocation of NF- } \\
\mathrm{kB}\end{array}$ & [179] \\
\hline & 16HBE140- & $\begin{array}{l}0.8 \text { and } 3.9 \\
\mu \mathrm{M}\end{array}$ & $24 \mathrm{~h}$ & $\mathrm{~N} / \mathrm{D}$ & $\begin{array}{l}\downarrow \mathrm{Ca}^{2+} \text { response to wound healing, } \mathrm{P} 2 \mathrm{Y}- \\
\text { and } \mathrm{P} 2 \mathrm{X}-\text { mediated } \mathrm{Ca}^{2+} \text { signaling } \\
\text { responses to ATP }\end{array}$ & [180] \\
\hline \multirow[t]{12}{*}{$\begin{array}{l}\text { Subacute/ } \\
\text { Subchronic }\end{array}$} & HAEC & $\begin{array}{l}133,333 \\
667,1335 \\
2670,6675 \\
\mathrm{nM}^{*}\end{array}$ & $<4 \mathrm{D}$ & N/D & $\begin{array}{l}\downarrow \text { mucin5AC and } 5 B \text { at both mRNA and } \\
\text { protein levels } \\
\uparrow \text { gene expressions of GMLM, HO1 and } \\
\text { NQO1 } \\
\text { Target retinoic acid (RA) signaling } \\
\text { pathway }\end{array}$ & [181] \\
\hline & LEC & $5 \mu \mathrm{M}$ & $<48 h$ & N/D & $\begin{array}{l}\uparrow \text { Intracellular oxidant level } \\
\uparrow \text { Heavy subunit of } \mathrm{y} \text {-GCS mRNA } \\
\uparrow \mathrm{c} \text {-fos and c-jun mRNA, and NFkB DNA } \\
\text { binding activities }\end{array}$ & [182] \\
\hline & CFBE410- & $1.3-667 \mathrm{nM}$ & Up to $4 D$ & N/D & $\begin{array}{l}\text { Activation of E3 ubiquitin ligase to promote } \\
\text { degradation of CFTR. }\end{array}$ & [183] \\
\hline & HELF & $1 \mu \mathrm{M}$ & $15 w$ & Yes & $\begin{array}{l}\uparrow \text { miRNA } 21 \text { expression } \\
\text { Activation of ERK and NFkB }\end{array}$ & [184] \\
\hline & 16HBE140- & $\begin{array}{l}130 \text { or } 330 \\
\mathrm{nM}\end{array}$ & For $4-5 w$ & N/D & $\begin{array}{l}\downarrow \text { Wound repair, ATP-mediated Ca- } \\
\text { signaling, P2Y receptor function and } \\
\text { molecular expression }\end{array}$ & [185] \\
\hline & $\mathrm{HBE}$ & $1 \mu \mathrm{M}$ & $15 w$ & N/D & $\begin{array}{l}\text { EMT } \\
\uparrow \text { Twist1 and Bmi1 regulated by HIF-2a }\end{array}$ & [174] \\
\hline & BEAS-2B & $1 \mu \mathrm{M}$ & $15 w$ & Yes & $\begin{array}{l}\text { Activation of STAT3 } \\
\uparrow \text { miRNA } 21 \text { and secretion of IL- } 6\end{array}$ & [173] \\
\hline & HELF & $1 \mathrm{uM}$ & $15 w$ & Yes & $\begin{array}{l}\text { Activation of ERK/NFkB, JNK/c-Jun, and } \\
\text { Akt. } \\
\uparrow \text { miRNA } 21 \\
\downarrow \text { PDCD4 and SPRY1 protein expression }\end{array}$ & [186] \\
\hline & BEAS-2B & $0.25 \mu \mathrm{M}$ & $<16 w$ & Yes & 个 IL6 and GM-CSF production & [177] \\
\hline & BEAS-2B & $\begin{array}{l}0.1,0.5,1 \\
\mu \mathrm{M}\end{array}$ & $<16 w$ & Yes & $\begin{array}{l}\downarrow \mathrm{H} 3 \mathrm{~K} 4 \mathrm{me} 3, \mathrm{H} 3 \mathrm{~K} 9 \mathrm{me} 2, \mathrm{HMT} \text { activities } \\
\uparrow \mathrm{KDM} 5 \mathrm{~A}, \mathrm{HDM} \text { activities }\end{array}$ & [187] \\
\hline & BEAS-2B & $1 \mu \mathrm{M}$ & $15 w$ & Yes & $\begin{array}{l}\downarrow \text { PDCD4 expression } \\
\uparrow \text { Twist } 1 \text { and miRNA } 21 \text { expression levels }\end{array}$ & [176] \\
\hline & HBE & $2.5 \mu \mathrm{M}$ & $13 w$ & Yes & $\begin{array}{l}\uparrow \text { miRNA } 155 \text { expression } \\
\Downarrow \text { NRF2 levels }\end{array}$ & [188] \\
\hline
\end{tabular}




\begin{tabular}{|c|c|c|c|c|c|c|}
\hline & BEAS-2B & $0.1-10 \mu \mathrm{M}$ & $<48 h$ & N/D & $\begin{array}{l}\uparrow \text { mitotic accumulation } \\
\text { Plk1 activation }\end{array}$ & [189] \\
\hline & BEAS-2B & $0.25 \mu \mathrm{M}$ & $12 w$ & Yes & $\begin{array}{l}\text { Macrophage activation } \\
\uparrow I L 10, T G F \beta, C C L 18, I L 12 \text { and CXCL11 } \\
\text { secretion } \\
\downarrow \text { Autophagic activity }\end{array}$ & [190] \\
\hline & BEAS-2B & $\begin{array}{l}1.25,2,2.5 \\
5,10 \mu \mathrm{M}\end{array}$ & $\begin{array}{c}48 \mathrm{~h} \text { and } \\
6 \mathrm{w}\end{array}$ & Yes & $\begin{array}{l}\Downarrow \text { miRNA } 31 \text { expression } \\
\uparrow \text { SATB2 protein and mRNA levels }\end{array}$ & [191] \\
\hline & BEAS-2B & $\begin{array}{l}0.25 \text { and } 2.5 \\
\mu \mathrm{M}\end{array}$ & $\begin{array}{l}48 \mathrm{~h} \text { and } \\
16 \mathrm{w}\end{array}$ & Yes & $\begin{array}{l}\text { Morphological, motile and proliferative } \\
\text { changes, activation of autophagy } \\
\uparrow \text { EMT via MEK/ERK } 1 / 2 \text { signaling }\end{array}$ & [192] \\
\hline & BEAS-2B & $0.5 \mu \mathrm{M}$ & $12 w$ & Yes & $\begin{array}{l}\uparrow \text { Increased metastatic potential } \\
\Downarrow \text { Metastatic potential of arsenic- } \\
\text { transformed lung epithelial cells from loss } \\
\text { of SOX9 }\end{array}$ & [193] \\
\hline & $\mathrm{HBE}$ & $2.5 \mu \mathrm{M}$ & $13 w$ & Yes & $\begin{array}{l}\text { 个 miR- } 106 \mathrm{~b} \text { and } 18 \mathrm{~b} \\
\mathrm{~m}^{6} \mathrm{~A} \text { level and its modification controlled by } \\
\text { its methyltransferases and demethylase }\end{array}$ & [194] \\
\hline & $\mathrm{HBE}$ & $\begin{array}{l}66.5,133 \\
\text { and } 667 \mathrm{nM}^{*}\end{array}$ & $6 \mathrm{D}$ & N/A & $\begin{array}{l}\downarrow \text { Expression of host defense genes, } \\
\text { lysozyme release and bactericidal activity } \\
\text { Alters transcriptional responses to } \\
\text { Pseudomonas aeruginosa }\end{array}$ & [195] \\
\hline & $\mathrm{HBE}$ & $1 \mu \mathrm{M}$ & $15 w$ & Yes & $\begin{array}{l}\uparrow \text { HIF-2 } \alpha, \text { miR-191, MMP-9, WT1 and } \\
\text { VEGF } \\
\downarrow \text { BASP1 }\end{array}$ & [196] \\
\hline & $\mathrm{HBE}$ & $1 \mu \mathrm{M}$ & $22 w$ & Yes & $\begin{array}{l}\uparrow \text { Nrf2-mediated antioxidant levels } \\
\Downarrow \text { ROS and MDA levels }\end{array}$ & [197] \\
\hline & $\mathrm{HBE}$ & $1 \mu \mathrm{M}$ & $15 w$ & N/D & $\begin{array}{l}\text { 个 Cell proliferation, STAT3 activation } \\
\text { Transfer of miR-21 via exosomes }\end{array}$ & [198] \\
\hline & $\mathrm{HBE}$ & $1 \mu \mathrm{M}$ & $15 w$ & Yes & $\begin{array}{l}\text { 个 Angiogenesis in vitro and in vivo, VEGF } \\
\text { expression }\end{array}$ & [199] \\
\hline & $\mathrm{HBE}$ & $1 \mu \mathrm{M}$ & $15 w$ & Yes & 个 Inflammation, IL-6 and IL-8 via HIF-2 $\alpha$ & [200] \\
\hline & 16HBE140- & $\begin{array}{l}0.8 \text { and } 3.9 \\
\mu \mathrm{M}\end{array}$ & $5 \mathrm{D}$ & N/D & $\begin{array}{l}\text { Alters protein and mRNA levels of tight } \\
\text { junction proteins in airway epithelial cells. }\end{array}$ & [201] \\
\hline Chronic & SAEC & $6.7 \mu \mathrm{M}^{*}$ & $24 w$ & Yes & $\begin{array}{l}\uparrow \text { Micronuclei incidence, PALA resistant } \\
\text { characteristics, c-H-ras, c-myc, and c-fos } \\
\text { protein expression. } \\
\downarrow \text { WT p53 expression and } \\
\text { hyperphosphorylated Rb }\end{array}$ & [202] \\
\hline & BEAS-2B & $0.25,1,5 \mu \mathrm{M}$ & $26 w$ & Yes & $\begin{array}{l}\text { 个 Cell proliferation } \\
\text { Activation of AKT, ERK, mTOR and } \\
\text { p70S6K1 pathways }\end{array}$ & [203] \\
\hline & BEAS-2B & $1 \mu \mathrm{M}$ & $26 w$ & Yes & $\begin{array}{l}\downarrow \text { miRNA } 99 \text { expression } \\
\uparrow \text { COX-2 and HIF-1a }\end{array}$ & [175] \\
\hline & HPL-1D & $2 \mu \mathrm{M}$ & $38 w$ & Yes & $\begin{array}{l}\text { Activation of AKT, ERK } \\
\uparrow \text { Cell proliferation, EMT markers, } \\
\text { HMOX1 and HIF-1a mRNA levels, MMP2 } \\
\text { activity } \\
\downarrow \text { PTEN and SLC38A3 mRNA levels }\end{array}$ & [78] \\
\hline & BEAS-2B & $0.25 \mu \mathrm{M}$ & $24 w$ & Yes & 个 miRNA 301a & [204] \\
\hline & BEAS-2B & $100 \mathrm{nM}$ & $24 w$ & N/D & $\begin{array}{l}\text { 个 TGFa protein and mRNA levels, EGFR } \\
\text { expression and activity }\end{array}$ & [42] \\
\hline & $\mathrm{HBE}$ & $2 \mu \mathrm{M}$ & $<48 h$ & N/D & $\begin{array}{l}\downarrow \text { Mitochondrial function } \\
\uparrow \text { Glycolytic metabolism, M2 polarization } \\
\text { of macrophages }\end{array}$ & [205] \\
\hline & BEAS-2B & $1 \mu \mathrm{M}$ & $26 w$ & Yes & $\begin{array}{l}\text { 个 HB-EGF, EGFR and ERK activation, } \\
\text { HIF-1 } \alpha \text { expression }\end{array}$ & [206] \\
\hline
\end{tabular}

* The original study used in $\mathrm{ppb}$ or $\mu \mathrm{g} / \mathrm{L}$

Duration in hours (h), days (d), and weeks (w). EGFR: Epidermal growth factor receptor; Hb-EGF: Heparin binding epidermal-like growth factor; ERK: Extracellular signal-regulated kinase; STAT3: Signal transducer and activator of transcription 3; IL: Interleukin; HIF: Hypoxia-inducible factor; JNK: c-Jun N-terminal kinase; PDCD4: Programmed cell death 4; TNFa: Tumor necrosis factor alpha; y-GCS: Gamma-glutamylcysteine cynthetase; P2Y: Purinergic receptors; EMT: Epithelial mesenchymal transition; BMI1: BMI1 polycomb ring finger oncogene; SPRY1: Sprouty1; H3K4me3: Histone 3 Lysine 4 trimethylation; H3K9me2: Histone 3 Lysine 9 dimethylation; HMT: Histone methyltransferase; HDM: Histone demethylase; KDM5A: Lysine demethylase 5A; PIK1: Phosphatidylinositol 4 kinase PIK1; CCL18: C-C motif chemokine ligand 18; CXCL11: C-X-C motif chemokine 11; SATB2: Special AT-rich sequence-binding protein 2; PALA: Nphosphonacetyl-I-aspartate; Rb: Retinoblastoma; mTOR: mammalian target of rapamycin; p70S6K1: p70-S6 kinase 1; COX-2: Cyclooxygenase-2; HMOX1: Heme oxygenase 1; PTEN: Phosphate and tensin; SLC38A3: Solute carrier family 38 member 3; TGFa: Transforming growth factor alpha 
The range of concentrations is consistent with the notion that there is no "correct" arsenic concentration or consensus in the field. To understand the mechanism of arsenic-induced diseases, both acute and chronic arsenic exposures were widely used in in vitro studies. Because both skin and lungs are the major target organs from arsenic exposure, this dissertation focuses on both acute and chronic arsenic effects on these organs.

\section{Acute arsenic study in vitro}

As discussed in the health effects of arsenic section, acute arsenic exposure does not lead to human carcinogenesis. However, in both skin and lung cell lines, acute (less than 24 hours) and subacute/subchronic (>24 hours but $<24$ weeks) arsenic exposures alter several cell cycle regulated genes, particularly Cyclin D1, and contributes to increased G2/M phase of cell cycle [152, 156, 158, 172]. Multiple lines of evidence show that cell cycle deregulation contributes to the development of cancer $[207,208]$. Furthermore, arsenic-exposed skin and lung cells have altered miRNA expression, mostly from acute and subacute/subchronic exposure. For example, miRNA21 is upregulated in both types of cells from arsenic exposure $[153,157,173,176]$. Increased expression of miRNA-21 is found to be a characteristic of cancer cells and alters cellular phenotypes, i.e., increased cell proliferation and invasion [209-211]. Despite these alterations, acute arsenic exposure does not induce cancer mainly due to a short duration of the exposure.

\section{Chronic arsenic study in vitro}

The chronic arsenic exposure that is associated with carcinogenesis in humans can be recapitulated in in vitro studies by exposing either lung or skin cells to arsenic for $>24$ weeks. Recognizing the need of elucidating arsenic-induced carcinogenesis, 
investigators have tried to identify the molecular basis for cell transformation and found the chronic arsenic treatment leads to an increase in metalloproteinase activity [165, $166,168]$, an increase in invasion and proliferation $[78,168,203]$, and alterations in gene expression that are involved in cell proliferation $[78,165,166,168,175]$. These observed data lead to further studies in understanding the mechanism of arsenicinduced transformation, as the clear mechanism of arsenic-induced carcinogenesis still remains elusive.

Interestingly, in skin cells, chronic arsenic exposure increased secretion of matrix metallopeptidases (MMP) and creatine kinases (CK) [165, 166, 168]. Particularly MMP9 has a role in remodeling extracellular matrix and cell surface protein cleavage. Its increased expression and activity are widely associated with cancer development [212]. Several population studies have shown increased MMP9 levels in individuals who ingested arsenic-containing drinking water at least for one year [213-216], which renders MMP9 as a strong prognostic marker for arsenic-induced cancer, as well as a possible driver of arsenic-induced carcinogenesis. Thus, in vitro studies can serve as reliable tools that reflect human exposure to arsenic.

Additionally, it is also important to note that the effects from chronic arsenic exposure may or may not occur under conditions of an acute exposure. Therefore, it is critical to have proper controls and identify the endpoint of each study to generate the most biologically meaningful in vitro studies.

iv. Proposed Mechanisms of Arsenic-induced Carcinogenesis

Proposed mechanisms of arsenic-induced carcinogenesis include oxidative stress [217-223], epigenetic changes including histone modification, miRNA expression, DNA methylation [93, 224-234], aneuploidy [235], and activation of oncogenic pathways [172, 236-253], such as the epidermal growth factor receptor (EGFR). The EGFR is a well- established biomarker of cancer [254-257], and studies have found that the EGFR 
is overexpressed in a variety of tumors and cancer cells, which correlates with poor patient prognosis [258-273], including NSCLC [274-276]. Both previous studies and our studies have shown acute arsenic exposure induces overexpression of EGFR in human bronchial epithelial cells [277] (Fig. 3). Despite a direct association between supraphysiological levels of arsenic and lung cancer, how chronic exposure to "a physiologically relevant" level of arsenic affect EGFR expression and signaling are not known.

\section{EGFR Biology}

\section{i. Structure and Activation of EGFR}

EGFR is a receptor tyrosine kinase (RTK) localized on the cell surface (Fig. 4). As one of the ErbB family receptors (EGFR, ErbB2, ErbB3, and ErbB4), EGFR is activated by specific ligands, and there are 7 endogenous EGFR ligands (epidermal growth factor (EGF), transforming growth factor- $\alpha$ (TGF $\alpha$ ), heparin binding epidermal growth factor (HB-EGF), amphiregulin (AREG), betacellulin (BTC), epigen (EPGN), epiregulin (EREG)). Of these ligands, HB-EGF and BTC are known to have a high affinity for the receptor and have robust signaling [278-280]. The EGFR and the other ErbB family members can be divided into three main domains: extracellular domain, transmembrane domain, and intracellular domain, which consists of a kinase domain and tyrosine residues on the $\mathrm{C}$ terminus that serve as docking sites for many downstream proteins. Ligand binding to the extracellular domain of the EGFR leads to a conformational change that allows receptor dimerization and activation of the intrinsic kinase activity. Once activated, the kinase from one receptor trans-phosphorylates tyrosine residues on the intracellular carboxy-terminus of its receptor pair (Fig. 4). These newly formed phosphotyrosines then serve as docking sites for downstream signaling 


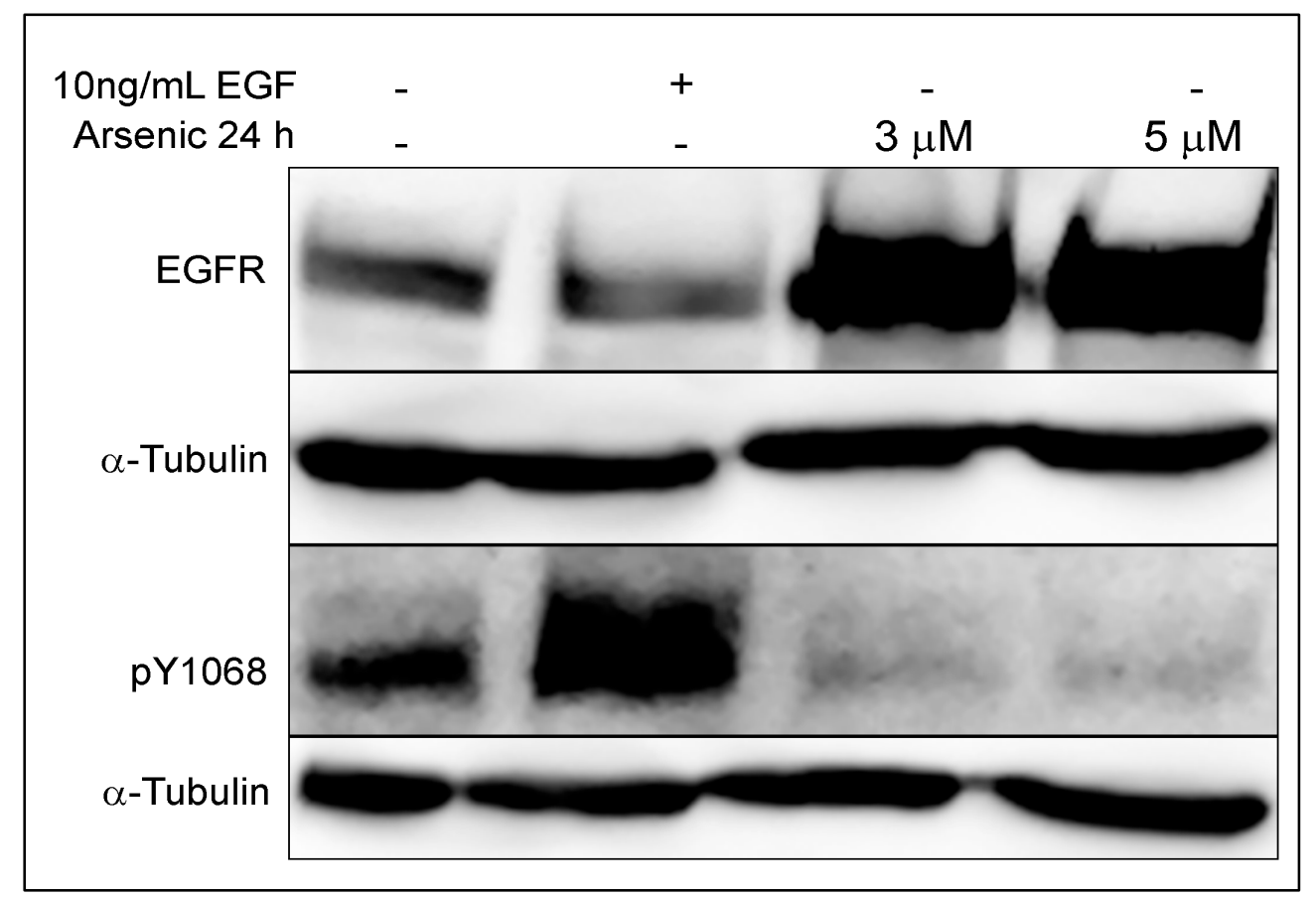

Figure 3. Acute arsenite induces overexpression of EGFR.

Immunblot of EGFR and phosphotyrosine 1068 (pY1068) in Beas-2B cells treated with arsenite at the indicated concentrations for 24 hours. $10 \mathrm{ng} / \mathrm{mL}$ of EGF treatment in Beas-2B cells was used as a positive control. EGF was stimulated after 2 hours of serum-starvation, and it was stimulated for 7 minutes. The samples were resolved on $7.5 \%$ SDS-PAGE. 


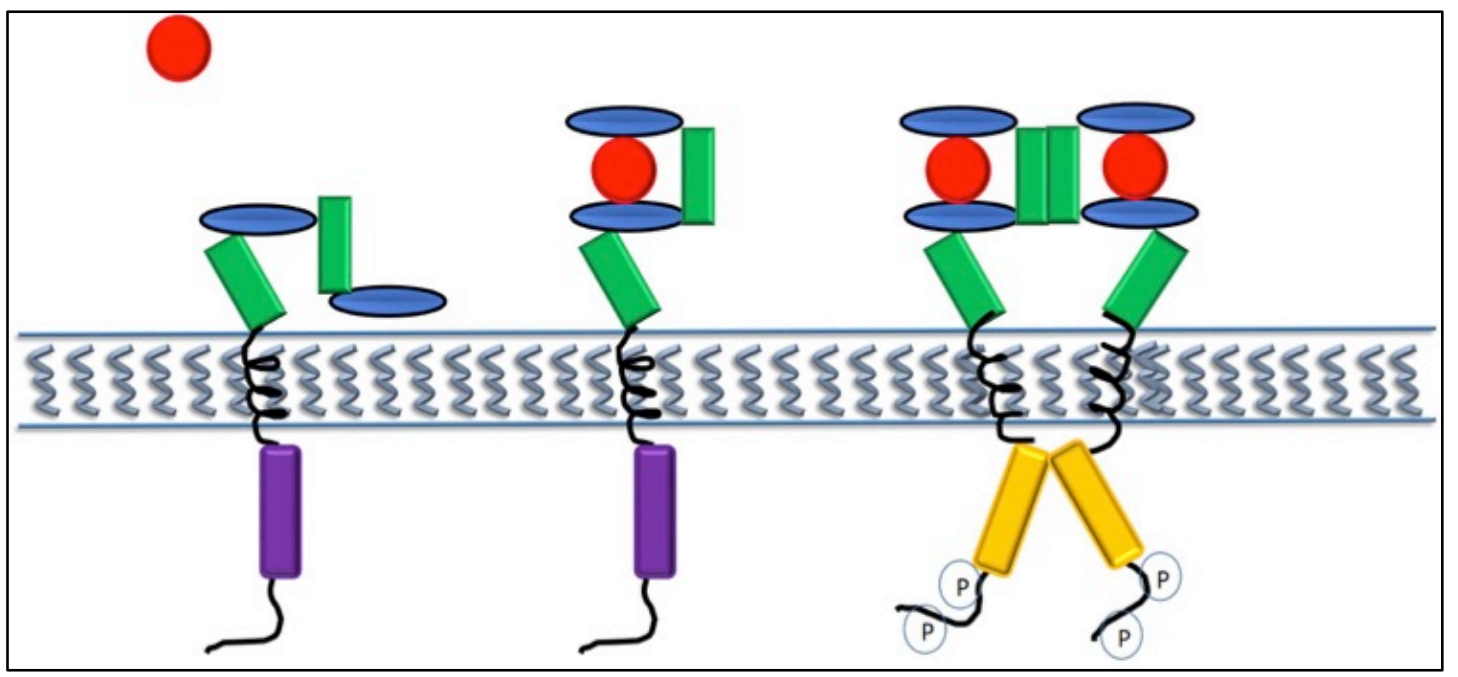

Figure 4. EGFR structure.

When the receptor is not occupied by a ligand, the cysteine-rich regions of the extracellular domain of the receptor interact with each other and maintain a "closed" conformation. When a ligand binds to the ligand binding domains of the extracellular domain, the EGFR undergoes a conformational change, exposing cysteine-rich regions. These regions, then, interact with other exposed cysteine-rich regions of another ErbB family receptor. This allows receptor dimerization and activation of the intrinsic kinase activity. Once activated, the intracellular kinase from one receptor trans-phosphorylates tyrosine residues on its receptor pair. These newly formed phosphotyrosines then serve as docking sites for downstream signaling proteins that mediate cell proliferation, survival, tumorigenesis, and differentiation. Red=ligand; green=cysteine-rich regions; blue=ligand-binding domains; purple=inactive kinase domains; yellow=active kinase domains. 
proteins (effectors) that mediate cell proliferation, survival, tumorigenesis, and differentiation.

\section{ii. EGFR Function in Embryonic Development}

The EGFR is a critical component in development. EGFR expression was observed in embryogenesis, and its ligands, specifically EGF and TGFa, were also expressed from 4- to 8-cell stage of embryogenesis [281-286]. The co-localization of the ligands with the EGFR throughout the critical stages of embryogenesis underscores the requirement of full activation of EGFR for proper development. Therefore, EGFR null and/or EGFR mutations are deleterious. Earlier studies have found EGFR null mice were either embryonically lethal or died shortly after birth [287]. The mice that had EGFR mutation manifested changes in hair and skin, which support the roles of EGFR in epithelial development [288, 289].

\section{iii. The Endocytic Trafficking Pathway of EGFR}

When a ligand binds to the EGFR, the activated EGFR gets internalized via clathrin-coated pits into the cell. Once the clathrin is shed, the vesicle then fuses with the early endosomes [290]. From the early endosomes, the receptors can have two different fates; the receptors can move back to the plasma membrane from the early endosomes (recycling), or the receptors can be degraded via lysosomes. For receptors to degrade, the receptors-containing early endosomes increase acidity to "mature" into the late endosomes [291]. The late endosomes then fuse with lysosomes to degrade the receptors (Fig. 5). The degradation of EGFR is tightly regulated to control the downstream signaling events, such as proliferation. Thus, improper regulation of degradation of EGFR can lead to overstimulation of proliferative signaling and contribute to cancer development. When the receptors are activated, the tyrosine residues of the 


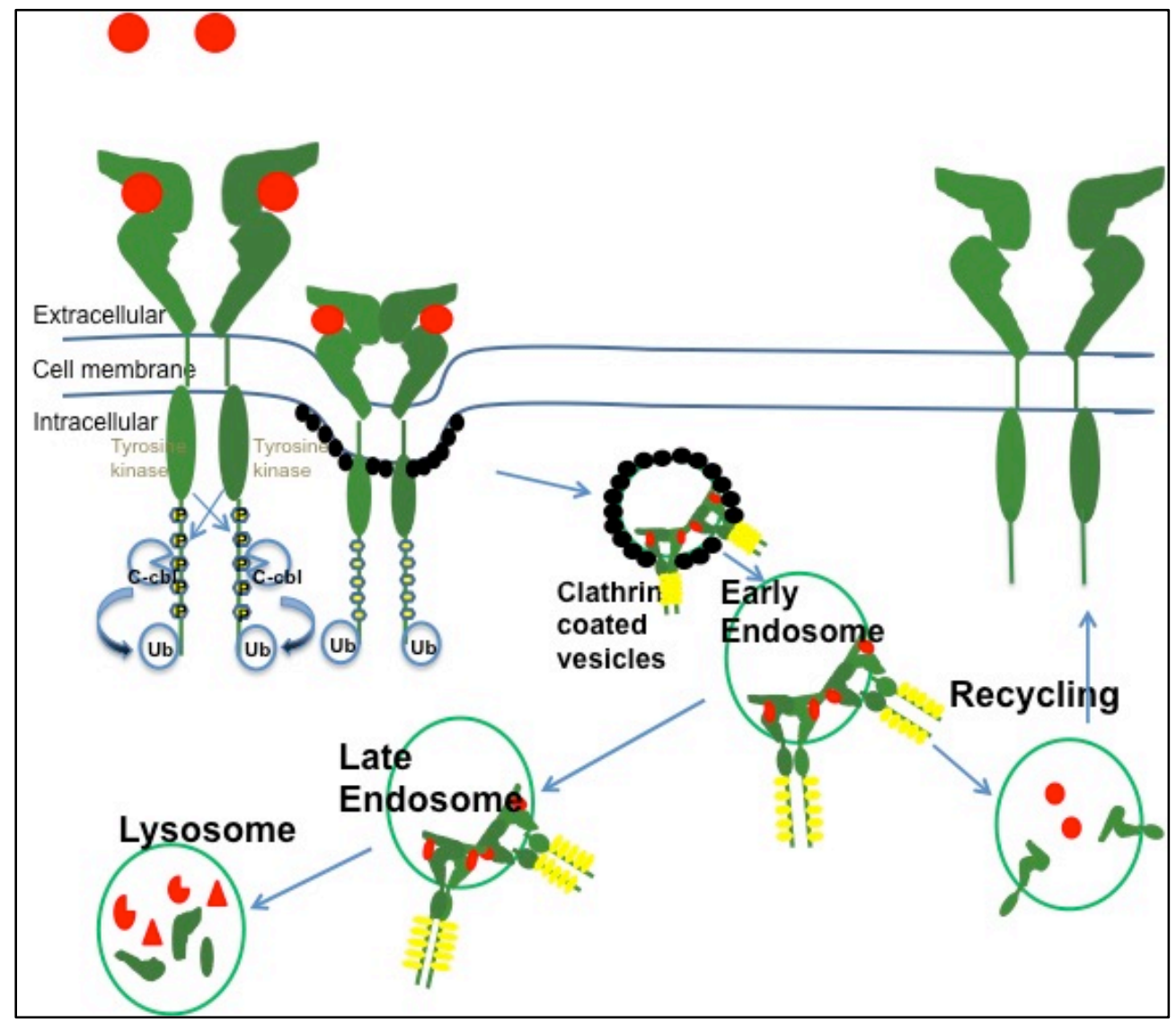

Figure 5. The endocytic trafficking pathway of EGFR.

When a ligand binds to the receptor, the receptors become activated. The activated tyrosine kinase domains then induce trans-phosphorylation of the tyrosine residues on the carboxy-terminus of its receptor pair. This phosphorylation triggers $\mathrm{c}-\mathrm{Cbl}$ to be recruited to the activated receptors and ubiquitinates the receptors. The activated receptors get internalized via clathrin-coated pits into the cell. Once the clathrin is shed, the vesicle then fuses with the early endosomes. From the early endosomes, the receptors can have two different fates; the receptors can move back to the plasma membrane from the early endosomes (recycling), or the receptors can be degraded via lysosome. 
kinase domain of the receptors get phosphorylated and get internalized into the cell. This receptor activation triggers $\mathrm{c}-\mathrm{Cbl}$, which is an E3 ubiquitin ligase, to be recruited and binds to a specific phosphorylated tyrosine residue (pY1045) of the kinase domain of the receptor [292]. This binding causes ubiquitination of the receptors and the receptors get marked for degradation via lysosomes [293, 294]. As mentioned earlier, the other fate of the internalized receptors is to recycle back to the plasma membrane. Previous studies have found even without any ligand stimulation, about $10 \%$ of the EGFR constitutively internalize and recycle back to the plasma membrane [295], predominantly by the basal expression of TGFa, an EGFR ligand that is involved in the recycling of the receptors [296]. EGF, on the other hand, is a well-known EGFR ligand, and EGF-stimulated EGFR undergo degradation. The different effects between TGFa and EGF ligands are mainly due to their sensitivity to the acidic environment [297]. TGFa is $\mathrm{pH}$ sensitive, and it is known to dissociate from the receptors at $\mathrm{pH}$ of about 6.8 , whereas $\mathrm{EGF}$ is dissociated from the receptors at $\mathrm{pH}$ of about 5.8 [298-300]. Thus, TGFa gets dissociated from the early endosome compartment ( $\mathrm{pH}$ of about 6.8), which allows the EGFR to recycle back to the plasma membrane, whereas EGF:EGFR complex endure the acidic environment until they get degraded [300]. The ErbB2 expression levels also affect the recycling pathway of the receptors. Studies have observed decrease in EGF-stimulated EGFR degradation in cells that overexpress ErbB2 [301, 302]. Further studies supported these observations by demonstrating ErbB2 overexpression preventing clathrin-mediated endocytosis of EGFR [301, 303]. However, a clear mechanism for ErbB2-induced impairment of EGFR endocytosis remains elusive.

\section{EGFR and Cancer}

There are four main events that can perturb the EGFR regulatory mechanisms, which all contribute to cancer development: 1) overexpression of EGFR, 
2) overproduction of its ligands, 3) improper receptor trafficking, and 4) the EGFR kinase domain mutations.

\section{i. Overexpression of EGFR}

The overexpression of EGFR (as compared to adjacent non-cancerous tissue) is seen in many cancers, including colorectal cancer, pancreatic cancer, NSCLC [276, 304310], and gliomas [311-316], and is associated with a poor prognosis. Under pathological conditions, such as cancer, the normal regulatory mechanisms of the signaling pathways are perturbed, resulting in hyperactivation of the signaling pathways. The overexpression of EGFR and its association with a poor prognosis can be explained by increased sites for the ligands to bind to the receptors, leading to enhanced downstream signaling events, such as proliferation.

\section{ii. Overproduction of the EGFR Ligands}

An increase in synthesis of ligands above the basal levels also triggers enhancement of the EGFR-induced activation of proliferative pathways. High levels of EGFR ligands, including EGF, TGFa, AREG, and BTC, were observed in cancers [317, 318]. The frequency of overexpression of EGFR and TGFa, has been observed in NSCLC patients, and predicts a poor outcome [305]. All ligands function similarly to EGF; they bind to the ligand binding domain of the receptors, and induce a conformational change in the receptors that leads to dimerization of the receptors and increased tyrosine kinase activity. However, their tissue distribution, expression regulation, and binding affinity and preferences on the receptors differ from one another, all of which can alter EGFR signaling by changing the endocytic trafficking itinerary [319323]. 


\section{iii. Improper Receptor Trafficking}

Disruption of proper EGFR trafficking is known to contribute to cancer development [324-331] mainly due to poor downregulation of the receptors and sustained downstream proliferative signaling. Without any ligand stimulation, the unstimulated receptors predominantly localize on the surface of the cells. However, when the cells are stimulated with ligand, such as EGF, the internalized receptor colocalizes with the early endosomes within 10 minutes post-stimulation [332]. Over time, the EGF-stimulated cells will have reduced staining of the EGFR in the early endosome compartment, due to its lysosomal degradation. However, when the EGFR endocytic trafficking pathway is perturbed, specifically between the early and the late endosomes, the EGFR will remain in the early endosome compartment and still active, prolonging the signaling as the EGFR accumulate in the early endosome compartment [333]. A previous study observed an increase in the EGFR protein expression level in response to prevention of the EGFR degradation [328], which suggests improper EGFR endocytic trafficking can contribute to both overexpression and hyperactivation of EGFR, leading to carcinogenesis. Thus, abnormalities in the endocytic trafficking of signaling receptors are now well-established hallmarks of malignant cells [334, 335].

iv. Kinase Domain Mutations.

Not only overexpression of the wild type EGFR, but also expression of the mutant EGFR kinase domain can contribute to cancer development. The most common EGFR kinase domain mutation is EGFRvIll, which is a deletion of residues 6 to 273 . Despite the inability to bind to the ligands, EGFRvIll is known to induce constitutive activation and trigger downstream signaling [336]. This form of receptor is known to enhance tumorigenesis, proliferation, and metastasis of tumors [337-340]. Such mutation is commonly observed in about $40 \%$ of glioblastoma cases [341-343]. Even 
though the overexpression of EGFR is commonly observed in NSCLC cases, there are only about 10 to $30 \%$ of NSCLC patients who are EGFR mutant positive [344]. The most common EGFR kinase domain mutations in NSCLC patients are exon 19 deletion, which is near the ATP-binding pocket that tyrosine kinase inhibitor (TKI) targets, and a mutation in exon 21 by substituting leucine 858 with arginine, or L858R [336, 345]. These kinase mutations cause constitutive activation of the EGFR by destabilizing the inactive conformation of EGFR [346, 347]. Therefore, NSCLC patients with the EGFR kinase domain mutations have better clinical response to $\mathrm{TKI}$, as the mutants are more sensitive to TKI than the wild type EGFR $[348,349]$. Unfortunately, patients with mutant EGFR kinase domain acquire resistance to the TKI therapy. A common EGFR kinase domain mutation that leads to resistance is T790M (substitution of threonine 790 with methionine). The location of T790 is significant, as it is located in the ATP binding pocket [350]. This substitution allows structural conformation of the receptors to gain near wild type levels of ATP affinity and allow ATP to bind to the kinase domain with higher affinity than the drug [350, 351], which supports T790M-induced resistance to TKI. Additionally, Shtiegman et al. observed decrease in endocytosis and downregulation of L858R- and T790M-containing EGFR, and continuous phosphorylation status of the receptors several hours following EGF stimulation, unlike the wild type receptors [326], which suggests prolonged downstream signaling and predisposition to lung cancer. Particularly, L858R-containing EGFR mutant had impaired recruitment and phosphorylation of c-Cbl with EGF stimulation [326].

\section{v. EGFR-targeted Chemotherapy}

Because of the importance of EGFR in cancer development, there have been several chemotherapeutic agents that target EGFR. The EGFR-targeting chemotherapeutic agents can be divided into two main classes: monoclonal antibodies 
and small molecule kinase inhibitor. An example of the monoclonal antibody is Cetuximab, which targets the extracellular domain of the receptor to prevent ligand:receptor interactions. This drug is approved for treatment of cancers, such as colorectal cancer and squamous cell carcinoma of the head and neck ( $\mathrm{NCl}, 2018)$. Erlotinib and getfitnib are examples of TKI, which bind to the kinase domain of the receptor to prevent activation of the downstream proteins and their signaling. Erlotinib is widely used as first-line therapy to treat particularly NSCLC patients [352]. As mentioned earlier, patients with mutant EGFR, such as L858R, have good responses to TKI, as they induce constitutive activation of the kinase, and such activity is found to increase sensitivity to the drug $[348,349,353]$. These specific mutations have higher affinity for TKI than does the wild type EGFR, and they have lower affinity for ATP, as compared to the TKI [346, 354]. Consistently, NSCLC cells with the mutant EGFR kinase domain have lower $\mathrm{IC}_{50}$ value of $\mathrm{TKI}$, as compared to the wild type EGFR [355]. Furthermore, TKI inhibited both EGFR activation and proliferation, and induced apoptosis in NSCLC cells with the mutant EGFR kinase domain, but it did not induce apoptosis in NSCLC cells with the wild type EGFR [348, 356, 357]. Interestingly, when the ErbB2 expression was blocked by monoclonal antibodies, enhancement of the mutant receptors' downregulation was observed [326], which highlights the importance of ErbB2 regulation. Thus, these studies suggest the complexity of the mutant receptors, and more specific targets-driven chemotherapeutic agents are needed. There are several irreversible inhibitors that target these mutations, and they act through covalent binding, but they are yet to be approved [350].

\section{EGFR and Arsenic-induced Carcinogenesis}

As mentioned above, both previous studies and our data have shown that acute high levels of arsenite exposure induce the overexpression of EGFR in human bronchial 
epithelial cells [277] (Fig. 3). Understanding the molecular mechanism of such phenomena will contribute to developing new drug targets. This dissertation examines the effect of an environmentally relevant level of arsenite on the EGFR signaling.

Arsenic readily accumulates in epithelial cells as they have high content of thiol groups, and EGFR plays a critical role in epithelial development. The interaction between arsenic and thiol groups supports the role of arsenic in lung cancer development through EGFR signaling axis in epithelial cells. In this dissertation, I suggest a potential role of chronic arsenite exposure in the regulation of components of the EGFR signaling axis. A previous study used micromolar ranges of arsenite, and observed increased level of EGFR ligand mRNAs, specifically HB-EGF [172]. HB-EGF is seen in a variety of cancers, such as colorectal, cervical, breast and gastric cancers [358-362]. Consistently, an earlier study demonstrated increase in TGFa mRNA expression levels in mice chronically exposed to arsenic-contaminated drinking water [363]. Also, overexpression of TGFa was observed in the tumor from nearly $50 \%$ of primary NSCLC patients [305]. As mentioned earlier, TGFa is an EGFR ligand that is involved in the constitutive recycling of EGFR, which can delay the EGFR lysosomal degradation [296], resulting in overexpression of the receptors. Thus, these studies support the hypothesis that arsenic has an impact on regulation of the ligands, resulting in overexpression of the EGFR.

There is a scant amount of studies that observe the effect on the receptor trafficking upon chronic toxicant exposure. A study has shown arsenic increases protein levels of Rab4, a protein involved in the recycling of EGFR [364]. This study suggests a potential role of arsenic in altering the endocytic trafficking of EGFR. Under normal conditions, EGFR internalizes via clathrin-mediated endocytosis, but at high doses of EGF, the EGFR undergoes clathrin-independent endocytosis, including caveolinmediated endocytosis [365]. This interplay between clathrin-mediated endocytosis and 
caveolin-mediated endocytosis controls the expression of EGFR in the cells to prevent overstimulation, as caveolin-mediated endocytosis preferentially couples to the EGFR degradation [366]. In our study, we observed overexpression of EGFR in response to chronic arsenic exposure (Fig. 7), suggesting a possible role of arsenic in dysregulating the interplay between the two distinct endocytic trafficking pathways, which contributes to arsenic-induced carcinogenesis by allowing overstimulation of EGFR signaling. Additionally, acute high levels of arsenic exposure is known to prevent microtubule disassembly by losing the integrity of the tubulins and mircotubules [367], and microtubules are critical components in movement of proteins between the organelles [368]. Thus, the EGFR endocytic trafficking pathway is a potential target site of chronic arsenic to induce overexpression of EGFR in the cells. Disruption of proper EGFR trafficking is known to contribute to cancer development, such as lung, pancreatic, and breast cancers [326, 328, 369]. Despite the importance of proper EGFR trafficking in cancer development, there has been no study that tested alterations in the route of EGFR trafficking from chronic arsenic exposure.

\section{Significance and Statement of Specific Aims}

Arsenic is ubiquitous; it can be found in water, air, and food. More than 200 million people worldwide are chronically exposed to arsenic [6]. These areas include Bangladesh, Chile, Mexico, and approximately $1 \%$ of the U.S. population, who rely on private wells for their water supply (US EPA, 2012a, 2012b) that have arsenic levels greater than $10 \mathrm{ppb}[46-48,370]$. There is a direct correlation between arsenic in drinking water and cancer development $[45,80,102,103,116-128]$, including non-small cell lung cancer (NSCLC). Proposed mechanisms of arsenic carcinogenicity include epigenetic [93, 224-226, 229, 230, 232], oxidative stress [217-223, 364, 371, 372], alteration in miRNA expression $[153,157,173,176,188,225,228,229,236,373-379]$, 
aneuploidy [235], and activation of oncogenic pathways [172, 237-242, 244-246, 249, 250, 252, 253, 377]. However, a clear arsenic-induced carcinogenic mechanism still remains elusive. To elucidate the carcinogenic mechanism, we are focusing on an established prognostic marker of cancer, EGFR [254-257]. The EGFR is overexpressed in a variety of tumors and cancer cells, and is commonly observed in NSCLC [274-276]. Both previous studies and our data (Fig. 1) show that acute arsenic exposure (1-10 $\mu \mathrm{M})$ induces overexpression of the EGFR $[237,277]$. However, how chronic arsenic exposure affects the EGFR expression and its signaling axis remain elusive.

My research goal was to understand how chronic arsenic exposure disrupts the EGFR signaling axis, contributing to overexpression of EGFR, and to develop strategies to mitigate the effect of arsenic toxicity. This aligns with the National Institute of Environmental Health Sciences' mission of discovering the impact of environmental toxicants on people to promote healthier lives. My hypothesis was that chronic arsenic exposure changes the EGFR signaling axis, which contributes to EGFR overexpression. The long-term goals were not only to identify novel roles of chronic arsenic exposure in the EGFR endocytic trafficking, but also to identify the key driver of chronic arsenicinduced increased cell migration that may contribute to developing a novel therapeutic target of lung cancer. My research was achieved by using BEAS-2B cells, which are non-malignant human lung bronchus epithelial cells generated by SV40 transfection [380]. They have been widely used to study heavy metal-induced carcinogenesis [381385], and they are commonly used in arsenic studies because the lungs are known to be one of the major target organs of inorganic arsenic carcinogenesis $[113,175]$.

My hypothesis was tested with the following aims:

\section{Aim 1: Measure the impact of acute and chronic arsenic exposure on the expression levels of the EGFR and its ligands.}


In order to achieve this aim, we performed western blots, RT-qPCR and ELISA. The goal of this aim was to determine the expression differences in EGFR as well as its ligands between untreated and arsenic treated cells and it is discussed specifically in chapter 2 .

\section{Aim 2: Determine the route and kinetics of the EGFR trafficking in arsenic-treated cells.}

We used flow cytometry to measure the cell surface. The goal of this aim was to determine the localization of EGFR in response to arsenic exposure and it is discussed specifically in chapter 2 .

\section{Aim 3: Assess EGFR dependency in chronic arsenic-induced increased cell migration.}

We used time-lapse microscopy to obtain live-cell imaging and measure effects of chronic arsenic exposure in cell speed, persistence and cell protrusion length. Chronic arsenic impact on cell migratory ability is discussed specifically in chapter 3.

The goal of this work was to provide a mechanism by which chronic arsenic acts on the EGFR signaling, which will lead to discovering novel therapeutic targets of NSCLC. The work proposed in Aim 1 and 2 gave us a biochemical effect of chronic arsenic exposure on the EGFR signaling axis and differentiated the impact of acute and chronic arsenic exposure in lung epithelial cells. More specifically, we discovered that chronic arsenic exposure increases cell surface level of EGFR supported by increased TGFa secretion. This work is discussed in Chapter 2 of this dissertation and has been published in Toxicology In Vitro in 2020. The work proposed in Aim 3 helped us to elucidate EGFR dependency in chronic arsenic-induced increased cell migration that may contribute to identifying a novel therapeutic target for lung cancer. This work is discussed in Chapter 3 of this dissertation. 


\section{CHAPTER 2}

\section{CHRONIC AND ACUTE ARSENIC EXPOSURE ENHANCE EGFR EXPRESSION VIA DISTINCT MOLECULAR MECHANISMS}

\section{Introduction}

Arsenic is ranked number one on the ATSDR Substance Priority List (ATSDR, 2017), and was classified as a group I "carcinogenic to humans" by the IARC in 1973 based on epidemiological carcinogenicity evidence in humans and in animal models [24]. Arsenic is ubiquitous in the environment and, depending on the dose and duration of exposure, can target many different types of tissues and organs, causing a wide array of adverse health effects, including vomiting, diarrhea, and cancer [43].

The lungs are one of the major target organs of arsenic $[75,175]$ as demonstrated in studies using female mice exposed to arsenic in utero or whole-life exposure [75], and supported by epidemiologic studies of children exposed to arsenic contaminated drinking water $[73,386]$. Countries that have high levels of arsenic in drinking water have some of the highest incidence of lung cancer in the world [123, 128, 130-132]. In particular, adenocarcinoma and squamous-cell carcinoma are the most prevalent among people with chronic arsenic exposure [102, 103]. Despite these associations, there are no clearly defined mechanisms by which chronic arsenic exposure induces carcinogenesis.

The epidermal growth factor receptor, EGFR is a cell surface receptor tyrosine kinase (RTK) that has important roles in developmental biology, tissue homeostasis and wound healing. Overexpression and hyperactivation of EGFR family members (i.e. EGFR, ErbB2, ErbB3, and ErbB4) have been well-characterized as biomarkers of a 
variety of cancers and are associated with poor patient prognosis [265, 309, 387-393]. Specifically, the overexpression and hyperactivation of the EGFR (as compared to adjacent non-cancerous tissue) is seen in up to $89 \%$ of NSCLC $[276,304,305,307$, $309,310,394,395]$. Given the association of ErbB family of RTKs with cancer, it is a logical candidate to link arsenic exposure and lung cancer.

Binding of one of seven endogenous ligands to the extracellular domain of the receptor leads to conformational changes that culminate in receptor dimerization and activation of the intrinsic kinase domain [396-398]. Once activated, the kinase from one receptor trans-phosphorylates tyrosine residues on the intracellular carboxy-terminus of its receptor pair. These phosphotyrosines are docking sites for downstream signaling proteins (effectors) that enhance cell proliferation, survival, tumorigenesis, and differentiation. Overexpression of the EGFR is commonly the result of one of four mechanisms: 1) increased transcription of the EGFR gene, 2) overproduction of its ligands, 3) slowed lysosomal degradation of the receptor, and 4) constitutively active mutations in the kinase domain. These events increase receptor tyrosine phosphorylation and enhance downstream signaling.

We hypothesized that chronic arsenic exposure modulates EGFR signaling axis by causing hyperactivation and overexpression of EGFR in lung epithelial cells, which can potentially contribute to lung carcinogenesis. This is supported by report that acute arsenite exposure (5-15 $\mu \mathrm{M}$ for 24 hours) increases EGFR expression in HeLa cells [277]. However, this level and duration of exposure and cell line do not accurately reflect what is observed in epidemiological studies. Thus, we examined the effects of acute versus chronic, and used an environmentally relevant level of arsenite exposure on BEAS-2B cells, non-malignant human lung bronchus epithelial cells immortalized by SV40 transfection [380]. BEAS-2B cells have proven to be an excellent model for studying arsenic-induced lung cell carcinogenesis [203, 381]. BEAS-2B cells were 
exposed to an arsenite concentration of $100 \mathrm{nM}$, which is the observed arsenic concentration in the plasma of individuals that chronically consumed arseniccontaminated drinking water, for 24 weeks.

\section{Materials and methods}

Cell culture

Human bronchial epithelial (Beas-2B) cells from American Type Culture Collection (Manassas, VA) were grown in growth media [LHC-9 media (Gibco)] on a matrix of fibronectin $(10 \mu \mathrm{g} / \mathrm{mL})$ and collagen $(35 \mu \mathrm{g} / \mathrm{mL})$ (FNC Coating Mix, AthenaES). Both acute and chronic conditions were grown on FNC coated plates. Chronic arsenite exposed cells were treated with $100 \mathrm{nM}$ sodium arsenite (final concentration) (CAS 7784-465-Fisher Scientific). Three cultures of each condition (0 or $100 \mathrm{nM}$ sodieum arsenite) were maintained separately for 24 weeks. Cells were propagated by trypsinization and plating at $1 \times 10^{6} \mathrm{cells} / 10 \mathrm{~cm}$ dish every $3-4$ days. Each week $1 \times 10^{6}$ cells/vial were frozen and stored in liquid nitrogen. The identity of untreated and sodium arsenite treated BEAS-2B cells was ensured by STR mapping after completion of 24 weeks in all three biological replicates (American Type Culture Collection, Manassas, VA). In experiments in which the cells were acutely exposed to 3 and $5 \mu \mathrm{M}$ of sodium arsenite for $24 \mathrm{~h}$, cells were grown in BEGM (Bronchial Epithelial Growth Medium) medium bulletkit (Lonza) without GA-1000 and EGF. This allowed for the selective removal of EGF while preserving the other media components necessary for cell viability. Cell morphology was examined under a light microscope (TE-2000; Nikon, Tokyo, Japan) with a 4x objective.

Cell lysate preparation 
When indicated, cells were serum-starved by washing twice with phosphate-buffered saline (PBS) in pH 7.3 and incubating in BEGM medium bulletkit (Lonza) without GA1000 and EGF. To harvest, cells were washed with PBS, incubated in 5 mM EDTA/PBS solution for $15 \mathrm{~min}$ at $37^{\circ} \mathrm{C}$ to dissociate the cells. Then the cells were counted using hemocytometer to ensure equivalent number of cells to be loaded on the gel. The cells were equilibrated to $4{ }^{\circ} \mathrm{C}$ by incubation on ice and harvested in ice cold RIPA buffer [150 $\mathrm{mM} \mathrm{NaCl}, 1 \% \mathrm{NP}-40,0.5 \%$ sodium deoxycholate, $0.1 \% \mathrm{SDS}, 10 \mathrm{mM}$ sodium pyrophosphate, $100 \mathrm{mM}$ sodium fluoride, $50 \mathrm{mM}$ Tris- $\mathrm{HCl}(\mathrm{pH}$ 8.0)] containing protease inhibitor, PMSF (EMD Millipore)]. Cells were solubilized by end-over-end rotation at $4{ }^{\circ} \mathrm{C}$. Insoluble material was removed by centrifugation at $21,130 \mathrm{xg}$ for $10 \mathrm{~min}$ at $4{ }^{\circ} \mathrm{C}$.

\section{Immunoblotting}

SDS sample buffer containing $10 \% \beta \mathrm{ME}$ was added to the cell lysates and heated at $95^{\circ} \mathrm{C}$ for 3 min. Equivalent amounts of sample were separated by $7.5 \%$ SDS-PAGE and electroblotted onto a nitrocellulose membrane. Membranes were immunoblotted with the following antibodies according to the manufacturer's directions: EGFR (1:1000 in 5\%milk/TBST; Santa Cruz, sc-03), pY1068 (1:500 in 5\% milk in TBST; Cell Signaling, 2234), and $\alpha$-tubulin (1:5000 dilution in 5\%milk; Sigma-Aldrich, T6199). Immunoreactive proteins were visualized by incubation with the appropriate horseradish peroxidaseconjugated secondary antibody (anti-mouse or anti-rabbit, Thermo Fisher) and enhanced chemiluminescence (ECL). Images were captured using a Fotodyne imaging system (Hartland, WI). Immunoreactive bands were quantified using ImageJ software [399].

Alamar Blue assay 
BEAS-2B cells were grown in LHC-9 media in 96-well microplates (10,000 cells/well) for $24 \mathrm{~h}$. Cells were treated with varying concentrations of arsenic for $24 \mathrm{~h}$, and serum-free medium was used as a control. Cell viability was determined using Alamar Blue Reagent (Bio-Rad) according to the manufacturer's directions. Cell-associated fluorescence was measured in Gen5 BioTek plate reader (excitation: 530 nm; emission: 590nm).

$R T-q P C R$

RNA was isolated from BEAS-2B cells by using RNAqueous-Micro Total RNA Isolation Kit (Thermo Fisher, AM1931). cDNA was synthesized using High-Capacity cDNA Reverse Transcription Kits (Thermo Fisher, 4368814). qPCR was performed using TaqMan Gene Expression Master Mix (Thermo Fisher, 4369016). The following primers were obtained from Thermo Fisher and previously validated: EGFR (Catalog\# 4331182, Assay ID Hs01076089), ErbB2 (Catalog\# 4331182, Assay ID Hs01001580_m1), EGF (Catalog\# 4331182, Assay ID Hs01099990_m1), AREG (Catalog\# 4331182, Assay ID Hs00950669_m1), BTC (Catalog\# 4331182, Assay ID Hs00156140_m1), and TGFa (Catalog\# 4331182, Assay ID Hs00608187_m1). The 96-well plate (Thermo Fisher, 4346906) was read using a StepOnePlus System (ThermoFisher, 4376600). GAPDH was used as a normalization control.

\section{Flow Cytometry}

BEAS-2B cells were dissociated with TrypLE Select Enzyme (Invitrogen) and resuspended at a density of $1 \times 10^{6}$ cells $/ \mathrm{ml}$ in growth medium. After washes with PBS, the cells were stained with phycoerythrin-conjugated anti-EGFR (BD, \#555997) for 30 minutes at room temperature, and flow cytometric analysis was performed using a BD FACSCalibur. Data analysis was performed with FlowJo (Tree Star). 


\section{ELISA}

The 96-well TGFa Microplates (abcam 100646) were coated overnight at $4^{\circ} \mathrm{C}$ with gentle shaking with $100 \mu \mathrm{L}$ of cell culture supernatants (from $2 \mathrm{ml}$ of a $80 \%$ confluent $60 \mathrm{~mm}$ dish) resuspended in $1 \mathrm{X}$ Assay Diluent $\mathrm{B}$. The plates were washed by filling each well with 1X Wash Solution using a 96-well plate auto-washer. The plates were then incubated with $100 \mu \mathrm{L}$ of $1 \mathrm{X}$ Biotinylated TGFa Detection Antibody for 1 hour at room temperature with gentle shaking. After the wash, the plates were then incubated with $100 \mu \mathrm{L}$ of $1 \mathrm{X}$ HRP-Streptavidin solution for 45 minutes at room temperature with gentle shaking. After washing, the plates were incubated with $100 \mu \mathrm{L}$ of tetramethylbenzidine (TMB) One-Step Substrate Reagent for 30 minutes at room temperature in the dark with gentle shaking. The ELISA Stop Solution was added and the absorbance was read at $450 \mathrm{~nm}$. Using the standard curve, the concentrations of TGF $\alpha$ were calculated.

Transwell assay

The 8- $\mathrm{\mu m}$ polycarbonate membrane, 6.5-mm inserts (Corning, Inc., Corning, NY) were moisturized with serum-free media for 30 minutes at $37^{\circ} \mathrm{C}$. After incubation, serum-free media containing the indicated concentrations of EGF and arsenic were added in the lower chamber. Media from BEAS-2B cells grown in $100 \mathrm{nM}$ sodium arsenite for 24 weeks (conditioned media) was harvested after 24 hours at $37^{\circ} \mathrm{C}$ in $5 \% \mathrm{CO}_{2}$. A density of 100,000 BEAS-2B cells were plated in the upper chamber of the insert (The cells were harvested as described above). The cells were allowed to migrate for 16 hours at $37^{\circ} \mathrm{C}$ in $5 \% \mathrm{CO}_{2}$. Migrated cells were then fixed in methanol, stained in Giemsa (3250-4, Ricca Chemical, Arlington, Texas), and counted under a microscope (TE-2000; Nikon, Tokyo, Japan) with a $20 x$ objective.

\section{Data Analysis}


Data were analyzed using Graphpad Prism 5.0 Software (Graphpad Software). Statistical tests are indicated in the figure legends.

\section{Results}

Chronic arsenite exposure increases EGFR expression and activity without altering cell morphology or viability

It has been previously demonstrated that HeLa cells acutely exposed to 5-15 $\mu \mathrm{M}$ arsenite increase EGFR protein expression [277]. To determine whether this was true in human lung epithelial cells (BEAS-2B cells), we repeated this experiment and found acute arsenite exposure (5 $\mu \mathrm{M}$ for 24 hours) caused a 1.5-fold increase in EGFR levels, but did not stimulate EGFR activity measured by pY1068 level (Fig. 6A). Additionally, we noted that acute arsenite exposure is accompanied by a decrease in cell viability and morphological changes to the cells (Fig 6B and 6C).

To more accurately model an environmentally relevant arsenic exposure, the lung epithelial cell line, BEAS-2B cells were exposed to $100 \mathrm{nM}$ of arsenite, which did not affect cell viability (Fig. 6B) or grossly impact cell morphology (Fig. 6C). As a control for the culturing process and propagation of the cells, three sets of "passage matched" cultures were maintained in parallel to the three arsenite exposed cultures. After 24 weeks in culture, all six cultures were subjected to Short Tandem Repeat (STR) profiling and were indistinguishable from the naïve BEAS-2B cells.

Over the course of 24 weeks of $100 \mathrm{nM}$ arsenite treatment, we sampled various time points $(0,6,12,18$, and 24 weeks). Arsenite treated cells displayed an increase in EGFR expression, as well as in receptor phosphorylation (Fig. 7) as compared to passage matched control. Interestingly, in all three biological replicates, we observed the peak of basal EGFR phosphorylation at 12 weeks. This increase in basal EGFR activity 
A.

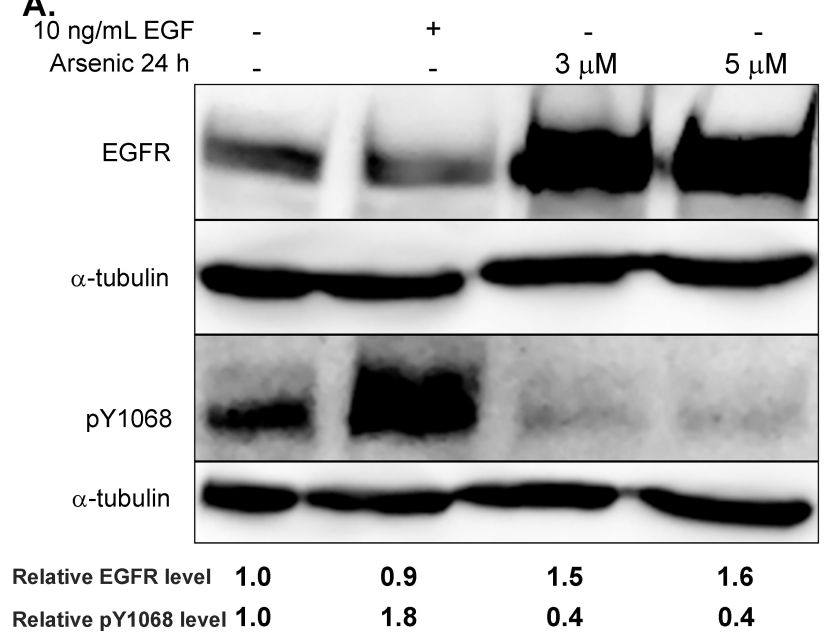

B.

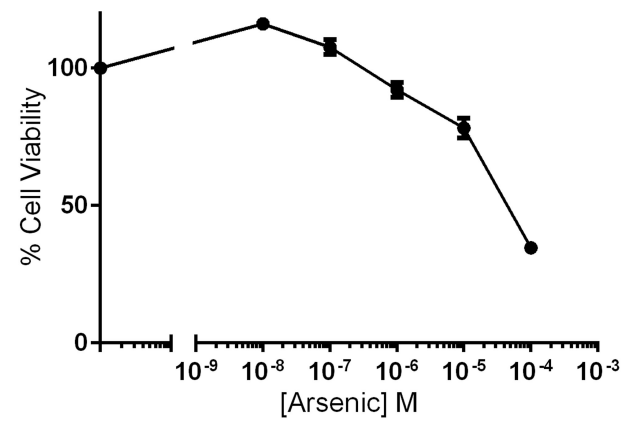

C.

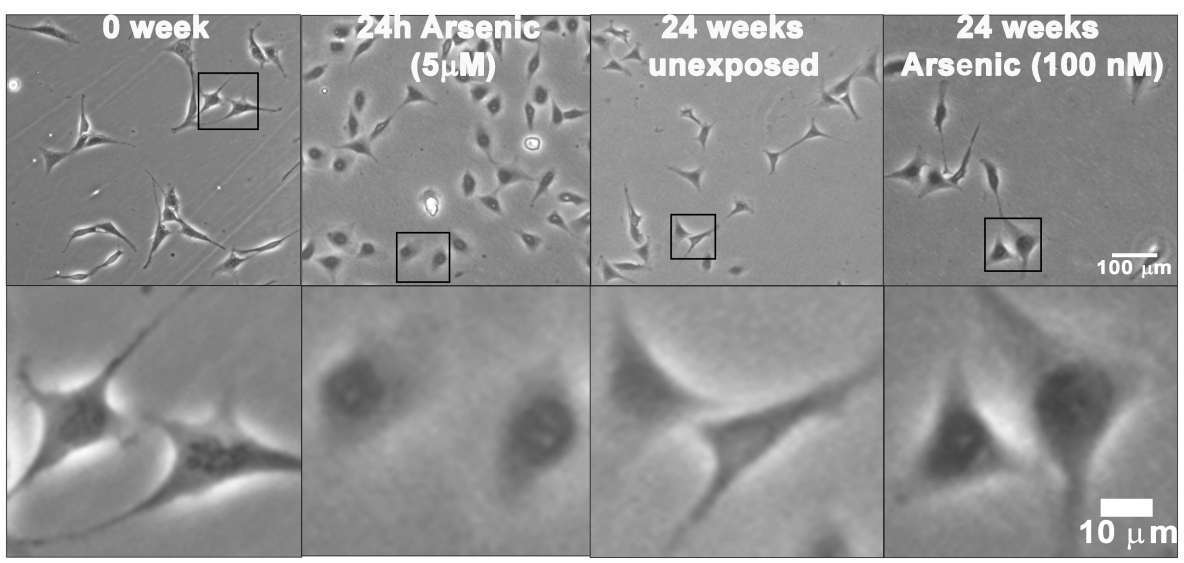

Figure 6. BEAS-2B cells exposed to acute arsenite have increased EGFR expression, altered cell morphology, and decreased viability.

A. BEAS-2B cells were treated with or without EGF $(10 \mathrm{ng} / \mathrm{ml})$ for 10 minutes or exposed to 3 or $5 \mu \mathrm{M}$ arsenite for 24 hours or no arsenic (-) as indicated. Cell lysates were prepared and equivalent number of cells $(100,000$ cells) were resolved by $7.5 \%$ SDSPAGE and immunoblotted for the presence of total EGFR, phosphorylated EGFR (pY1068), or $\alpha$-tubulin as a loading control. Relative levels of EGFR and phosphorylated EGFR are indicated below the immunoblot. Shown is a representative blot from three independent experiments. B. BEAS-2B cells were exposed to varying concentrations (0$100 \mu \mathrm{M})$ of sodium arsenite for 24 hours. Cell viability was assayed using Alamar Blue. Data are plotted as the average percentage of viable cells (compared to $0 \mu \mathrm{M}$ sodium arsenite $) \pm S D(n=3)$. The concentration that is used in this study, $100 \mathrm{nM}\left(10^{-7} \mathrm{M}\right)$, does not decrease the cell viability. C. Representative micrographs showing the morphology of BEAS-2B cells with and without arsenite treatment. Upper row is a $4 \mathrm{X}$ magnification (size bar $=100 \mu \mathrm{m})$, bottom panels show magnified boxed areas in top panel (size bar $=$ $10 \mu \mathrm{m})$. 


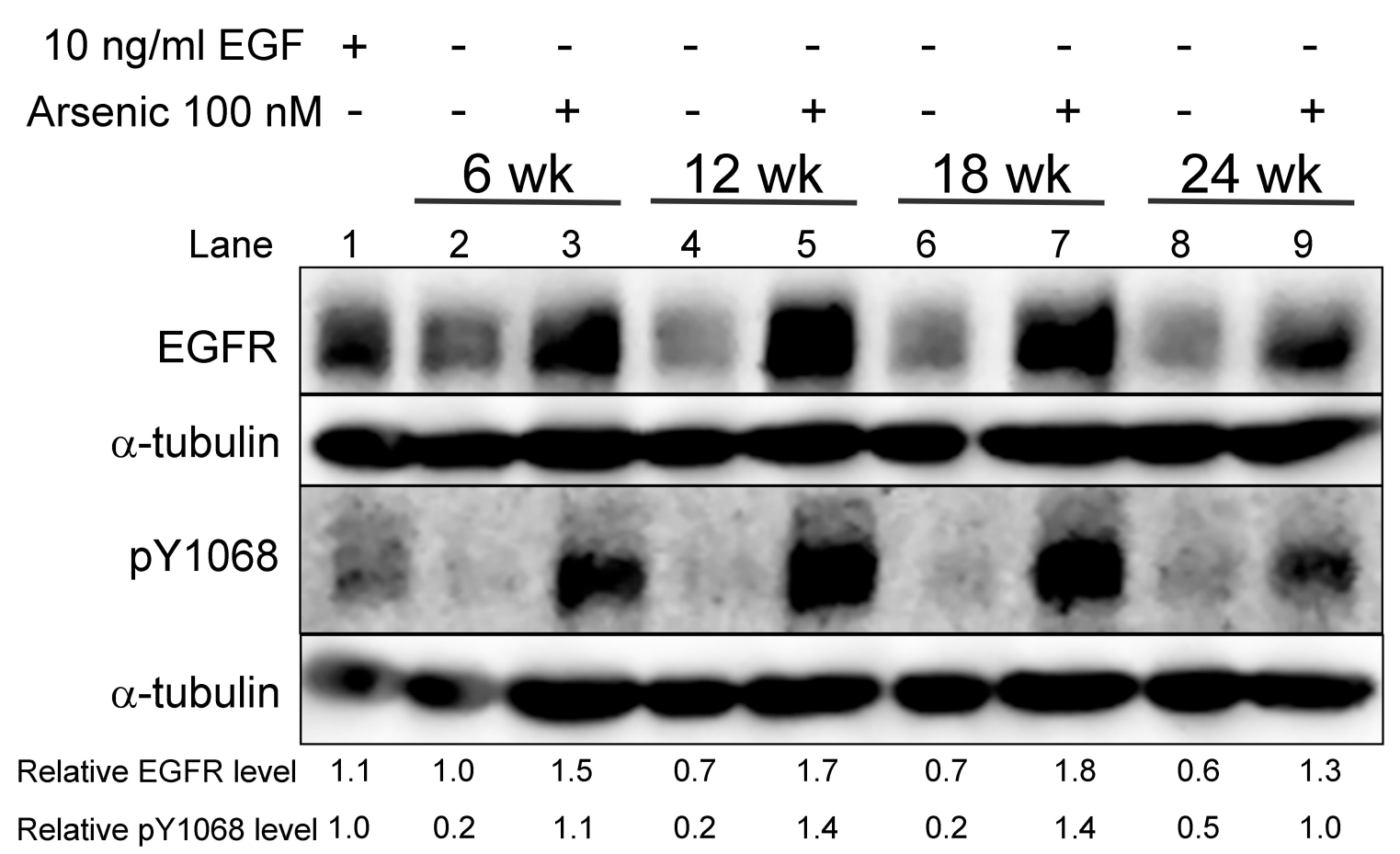

Figure 7. Chronic arsenite exposure induces EGFR expression and basal phosphorylation.

BEAS-2B cells were treated without (-, even lanes 2-8) or with (+, odd lanes 3-9) $100 \mathrm{nM}$ sodium arsenite for $6,12,18$, or 24 weeks. As a positive control for EGFR tyrosine phosphorylation, naïve BEAS-2B cells were treated with $10 \mathrm{ng} / \mathrm{ml} E G F$ for 7 minutes (Lane 1). Cell lysates were prepared and equivalent number of cells $(100,000$ cells/lane) were resolved by $7.5 \%$ SDS-PAGE and immunoblotted for total EGFR expression and phosphorylation at tyrosine 1068 (pY1068). $\alpha$-tubulin was used as a loading control. Shown is a representative blot from three independent experiments. 
after chronic, low level arsenite exposure is in stark contrast to the absence of detectable receptor phosphorylation in cells treated with 3 or $5 \mu \mathrm{M}$ arsenite for 24 hours (Fig. 6A).

Chronic arsenite exposure increases cell migratory ability in a ligand-independent manner.

To determine if there was a biological consequence of the increased basal EGFR activity from chronic arsenic exposure, we performed transwell migration assay to measure the migratory ability of naïve, acute arsenite treated, 24 weeks passage matched, and 24 weeks arsenite treated cells with and without EGF treatment (Fig. 8). Naïve, acute arsenite treated and passage matched cells exhibited approximately 2 -fold increase in EGF dependent cell migration (Fig. 8). In contrast, BEAS-2B cells chronically treated with arsenite had an elevated rate of cell migration, and a small marginal increase with EGF treatment (Fig. 8) shown with the highest $p$ value $(p=0.1800)$.

Chronic arsenite increases cell surface level of EGFR.

Next, we investigated the localization of EGFR by measuring the cell surface levels. A fluorescently-tagged [phycoerythrin (PE)-conjugated] anti-EGFR antibody that recognizes the extracellular domain of the receptor was incubated with BEAS-2B cells to measure the cell surface level of EGFR. Fluorescent Activated Cell Sorting (FACS) determined the amount of cell-associated fluorescence, which served as an indirect measure of cell surface EGFR. As compared to naïve, acute arsenite treated, and passage matched cells, cells chronically exposed to a low level of arsenite for 24 weeks had the highest median fluorescent intensity (MFI) values (Fig. 9A), indicating there were more cell surface EGFR. Acute arsenite $(5 \mu \mathrm{M})$ exposed cells had a significant 


\section{Cell Migration}

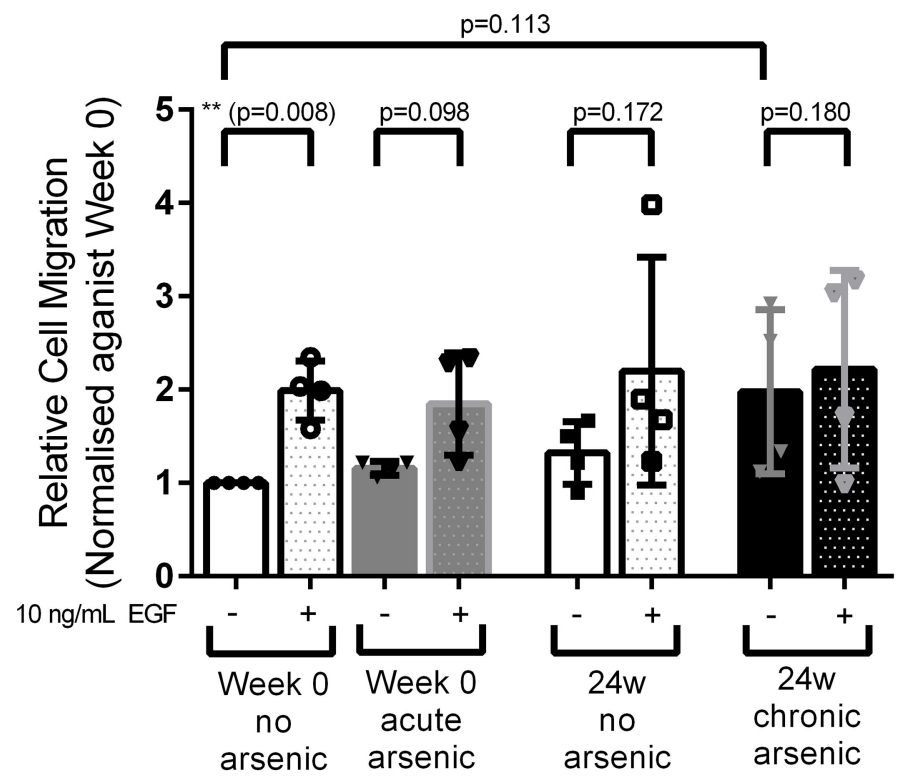

Figure 8. Chronic arsenite exposure increases ligand-independent cell migration. Naïve, passage matched and 24 weeks arsenite treated cells were plated onto the upper chamber of a $0.8 \mu \mathrm{m}$ transwell and treated without or with $10 \mathrm{ng} / \mathrm{mL}$ EGF for 16 hours. The cells that migrated through the transwell were fixed with methanol and stained with Giemsa. Total 10 fields were imaged per sample to count the number of migrated cells. The numbers of migrated cells were then normalized to naïve cells without arsenite treatment. Individual symbols represent the fold change in the number of migrated cells from each experiment $(n=4)$. Data were analyzed by two-way ANOVA (Graphpad Prism). 


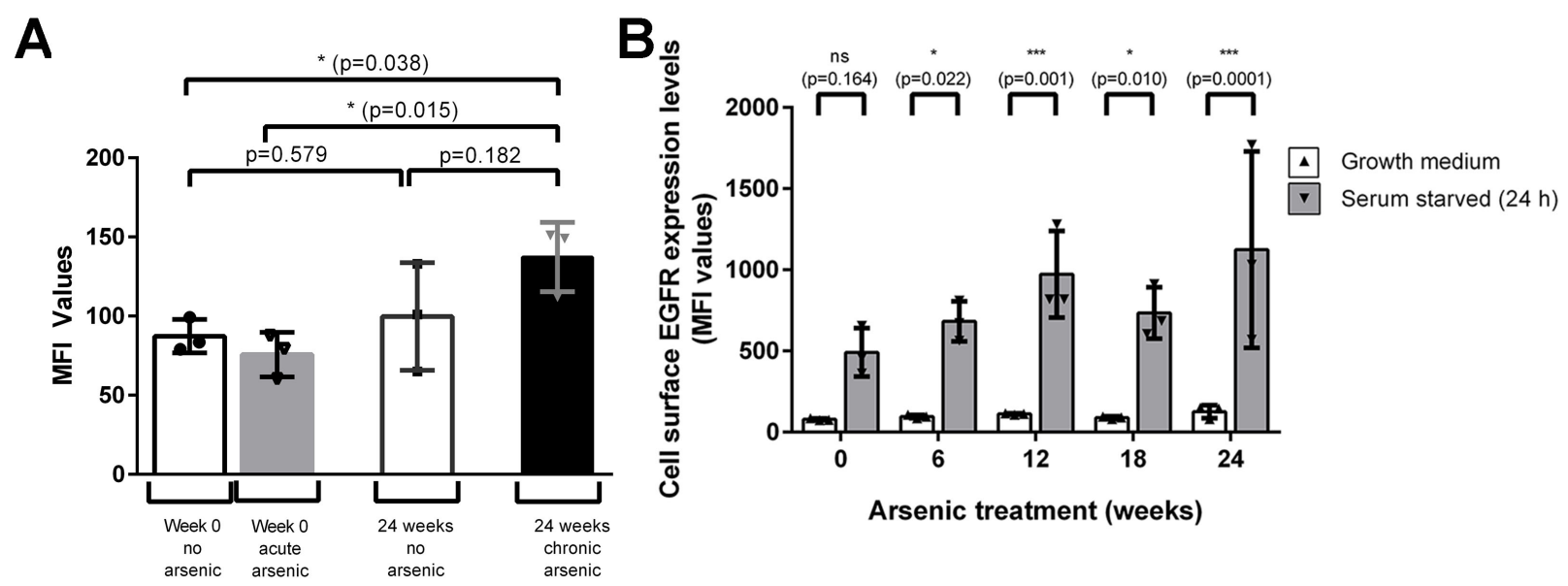

Figure 9. Acute and chronic arsenite exposure differentially affect cell surface levels of EGFR.

The cell surface level of EGFR was measured by incubating cells with phycoerythrin (PE)-conjugated EGFR antibody that binds to the extracellular domain of the receptor. Cell surface levels of EGFR were monitored by 5,000 cells/experiment by Fluorescent Activated Cell Sorting (FACS). A. Data are plotted from 24-week passage matched BEAS-2B cells that were treated without and with acute arsenite $(5 \mu \mathrm{M})$, and 24-week chronic arsenite $(100 \mathrm{nM})$. Individual symbols represent the mean fluorescence intensity $(M F I)$ from each experiment $(n=3)$. The bars and error bars represent the average MFI \pm S.D. Data were analyzed by two-way ANOVA (Graphpad Prism). B. Cells from varying times of $100 \mathrm{nM}$ arsenite treatment were maintained in growth media (clear bars) or serum starved for 24 hours (grey bars) to washout ligands and cause receptors to redistribute to the plasma membrane. Individual symbols represent the mean fluorescence intensity (MFI) from each experiment $(n=3)$. The bars and error bars represent the average MFI \pm S.D. Data were analyzed by two-way ANOVA (Graphpad Prism). 
decreased cell surface level of EGFR as compared to the chronically exposed cells $(p=0.015)$. To characterize the level of intracellular EGFR, we serum starved the cells to redistribute intracellular receptors to the plasma membrane. Cell surface levels of the EGFR were examined using the PE-conjugated anti-EGFR antibody and FACS. The comparison of basal cell surface expression (in growth media) versus induced cell surface expression (serum starved) indicates there is a time-dependent increase in the total and percentage of intracellular EGFR (Fig. 9B).

Chronic arsenite treatment increases TGF $\alpha$ expression.

We next determined if chronic arsenic exposure increased transcription of the proximal components of the EGFR signaling axis. Acute arsenic exposure has been reported to increase expression of EGFR and its ligands [172, 277, 363, 400, 401]. Quantitative PCR (qPCR) was used to assay mRNA levels of EGFR (Fig. 10A) and its closely related family member ERBB2 (Fig. 10B), as well as four endogenous EGFR ligands [epidermal growth factor (EGF), transforming growth factor- $\alpha$ (TGF $\alpha$ ), amphiregulin (AREG), and $\beta$-cellulin (BTC)] (Fig. 10C-F). In acute arsenite exposure, only BTC mRNA level significantly increased $(p<0.0001)$. Over the course of 24 weeks, the EGFR mRNA levels remained indistinguishable from control cells; ERBB2 levels were elevated in one of the three biological replicates. The average TGF $\alpha$ mRNA level increased starting at 6 weeks of arsenite treatment and steadily climbed over the 24 week time course and had the highest ligand mRNA level of all four ligands examined. The TGF $\alpha$ mRNA levels approached, but did not achieve, statistical significance ( $p=$ $\left.0.055, r^{2}=0.756\right)$ by the criteria set by Bryhn and Dimberg [402]. This is likely due to biological variability among the replicates $(1.7-10.3$ - fold over untreated cells). There were other changes in ligand mRNA. For instance, EGF mRNA levels increased in the 
A

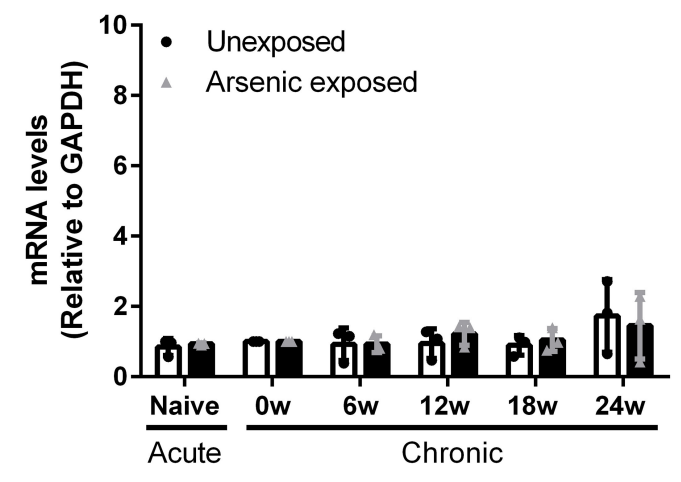

C

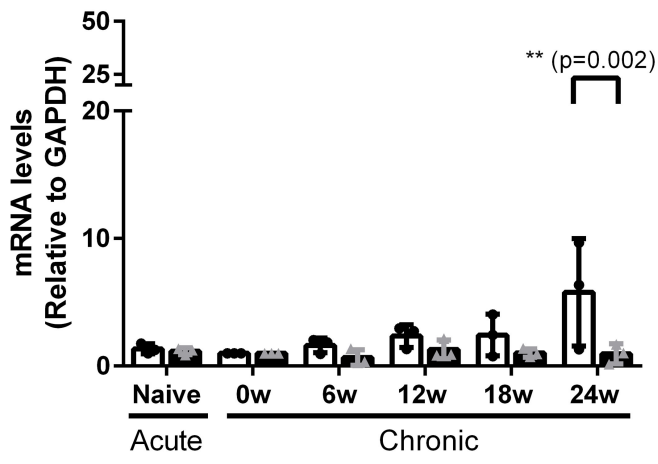

E

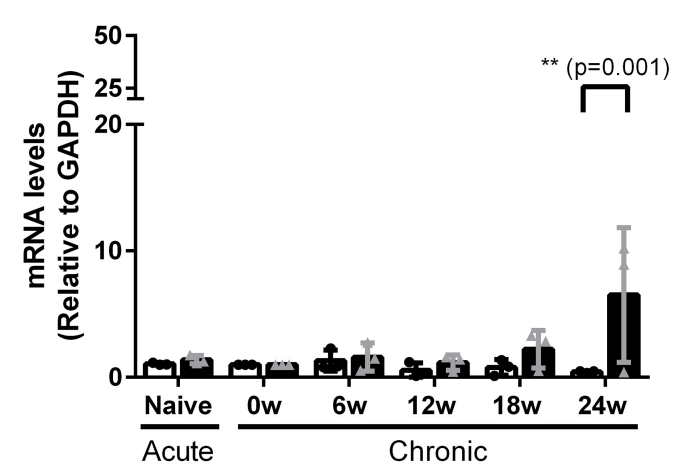

B

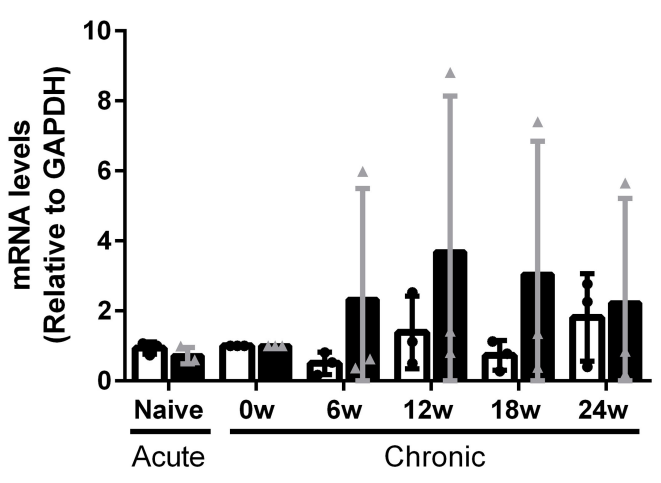

D

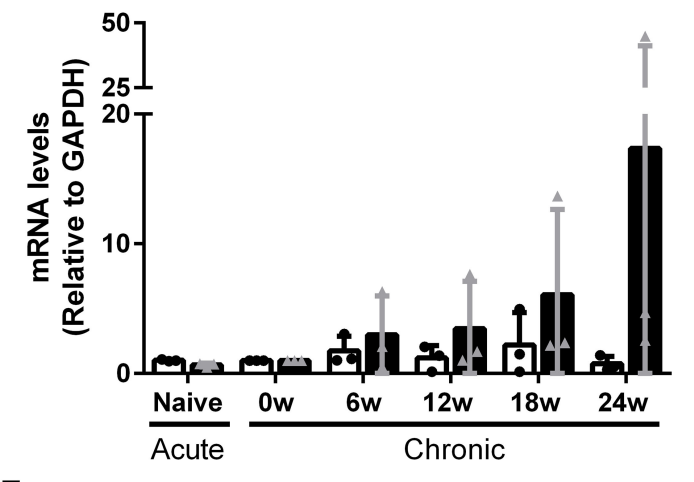

F

BTC

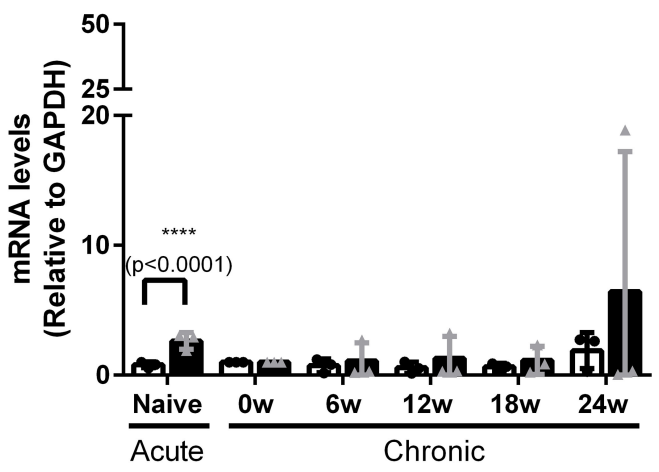

Figure 10. mRNA levels of the EGFR signaling axis in response to arsenic treatment.

RNA was isolated from BEAS-2B cells treated without or with $100 \mathrm{nM}$ sodium arsenite $(0$, $6,12,18$, or 24 weeks) and with $5 \mu \mathrm{M}$ sodium arsenite (24 hours), and reverse transcribed to cDNA. Individual genes were amplified using qPCR and commercially available primers (Thermo Fisher). Graphs are separated by receptors [EGFR (A) and ERBB2 (B)] and ligands [Epidermal growth factor (EGF), Transforming growth factor- $\alpha$ (TGF $\alpha$ ), Amphiregulin (AREG), and $\beta$-cellulin (BTC), (C-F)]. Data are plotted as the foldincrease in gene expression (relative to 0 week) normalized to the average GAPDH levels. Each biological replicate is represented by the symbols. The bars indicate the average \pm S.D. $(n=3)$. 
passage matched samples. In addition, AREG and BTC mRNA levels increased at 24 weeks as compared to the untreated cells. Because the levels of these ligands increased only at the 24 week time point, it was not pursued because it did not match the kinetics of EGFR activity (Fig. 7).

To determine if the increases in TGF $\alpha$ mRNA levels observed in chronic arsenite exposure were reflected by commensurate changes in TGF $\alpha$ protein levels, we performed an ELISA. At all four time points examined and all biological replicates, there was an increase in TGF $\alpha$ levels as compared to untreated cells (Fig. 11). These differences were most evident after 24 weeks of $100 \mathrm{nM}$ arsenite exposure; TGF $\alpha$ levels in the media increased up to an average concentration of $58 \mathrm{pg} / \mathrm{mL}$ and achieved statistical significance $(p=0.0062)$. These data are consistent with a previous study that observed increased concentration of TGF $\alpha$ in urothelial cells of Mexican populations exposed to arsenic [403].

\section{Discussion}

Many studies have investigated how cellular toxicity and carcinogenesis are associated with arsenic exposure [172, 203, 219, 225, 234-238, 240-246, 277]. However, our study sets itself apart because it examines 1) the cells that accurately model lung epithelial carcinogenesis, 2) environmentally relevant arsenic concentrations, and 3) the kinetics of cellular changes. These findings more accurately reflect cancer development than do results from acute exposure. Our data expose important differences between acute and chronic arsenic exposure. These differences include cell morphology, cytotoxicity, EGFR activity and subcellular distribution indicating that the two treatment conditions induce EGFR expression using distinct mechanisms. The 


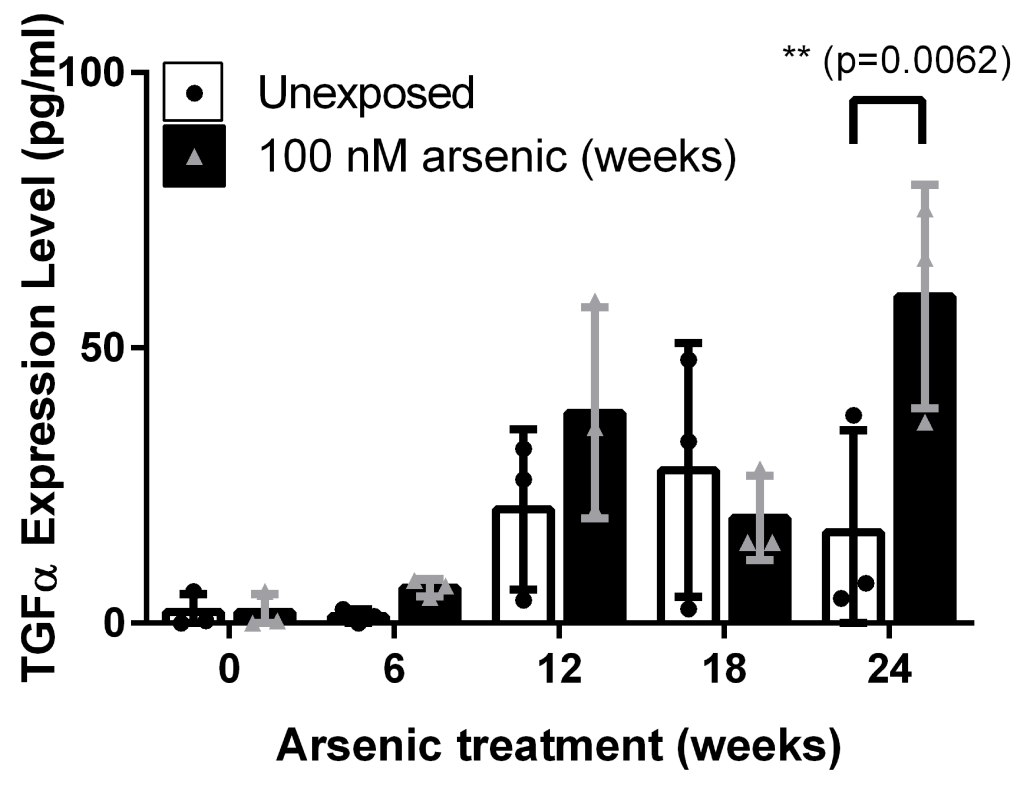

Figure 11. Chronic arsenite significantly increases TGF $\alpha$ protein levels.

BEAS-2B cells were treated without or with $100 \mathrm{nM}$ arsenite for $0-24$ weeks as indicated. TGF $\alpha$ levels in the supernatant from passage matched and chronic arsenite treated cells were determined by ELISA. Data points represent the average TGF $\alpha$ concentration (of two technical replicates). Bars represent the mean concentration \pm S.D. for each of the biological replicates $(n=3)$. Data were analyzed using a two-way ANOVA (Graphpad Prism). 
findings in this study are relevant to events occurring during arsenic exposure induced lung carcinogenesis. We investigated EGFR signaling in a model of chronic low level arsenite exposure in non-malignant human bronchial epithelial cells. We found that 24weeks of $100 \mathrm{nM}$ arsenite exposure increased both EGFR expression and activity (Fig 2), which contributed to increased cell migratory ability (Fig 3). In contrast to both naïve and passage matched cells, cells chronically treated with arsenite did not have an appreciable increase in its migratory ability with addition of EGF because receptor basal activity was already increased. At the same time, we observed an increase in the cell surface level of EGFR, as well as a progressive increase in TGFa levels (Figs. $4-6$ ). This significant difference in the cell surface expression level of EGFR between acute and chronic arsenite exposure further highlights their possible differential mechanistic pathways. We also observed an increase in the amount of intracellular EGFR in cells chronically exposed to arsenite (Fig. 4B). This finding suggests that increased levels of TGFa not only triggers recycling of the receptor to induce increased cell surface level of EGFR, but also changes the dynamics of the EGFR trafficking, which diverts the ligand:receptor complex from the lysosome thus preventing degradation and signal termination [296-300], leading to increased basal EGFR activity (Fig. 2). It is wellestablished that arsenic toxicities are highly dose- and time-dependent. The usual acute toxicity symptoms include diarrhea, vomiting, dehydration and hypotension, whereas chronic toxicity symptoms include cancer, cardiovascular disease, and respiratory disease. These symptoms support my findings of different impacts on BEAS-2B cells from acute and chronic arsenite exposure.

In many ways, the ability of arsenic exposure to increase ligand production is not surprising. Acute high level arsenic exposure has been reported to increase mRNA expression for other endogenous EGFR ligands (i.e. HB-EGF) [172]. However, the previous experimental protocols that use acute high level arsenic exposure do not 
accurately reflect what is observed in the human population. Future studies are warranted to determine whether chronic low level arsenic exposure differentially affects EGFR growth factor production and if those effects are cell type specific.

It is noteworthy that the concentration of secreted TGFa in chronic arsenite treated cells is low (ranging from $4.5 \mathrm{pg} / \mathrm{mL}$ to $75.28 \mathrm{pg} / \mathrm{mL}$ ). We noted this concentration is lower than the ligand's affinity for the EGFR ( $\mathrm{Kd}=4.6 \mathrm{nM}$ or 25,300 $\mathrm{pg} / \mathrm{mL}$ ) [404]. We need additional studies to understand how these low concentrations of TGFa lead to EGFR activity. There are several studies that have observed malignant effects of TGFa in an autocrine manner in various types of cancer, including NSCLC [405-411]. Alternatively, TGFa may communicate with cells via exosomes as has been reported in other arsenic-transformed cells [412]. Isolating exosomes from chronicarsenic treated cells and measuring the levels of TGFa could provide additional information on the potential signaling mechanism. Also, additional studies are warranted to determine key events that lead to observed secretion of TGFa.

Despite the need to reconcile some mechanistic details, our observation is consistent with the previous reports that nearly $50 \%$ of NSCLCs are characterized by increased TGFa [305]. Furthermore, there are associations between arsenic exposure and TGFa mRNA levels in skin tissues of mice chronically exposed to arseniccontaminated drinking water [363], as well as TGFa protein levels in bladder urothelial cells of individuals chronically exposed to arsenic-contaminated drinking water [403]. Further, as a mechanism to increased EGFR expression and activity, TGFa is logical from a receptor biology perspective. TGFa and EGF bind EGFR with comparable affinity at physiological $\mathrm{pH}$, but TGFa binding is more sensitive to $\mathrm{pH}$ changes. For instance, $50 \%$ of TGFa will dissociate from the EGFR at $\mathrm{pH}$ of about 6.8 , whereas a $\mathrm{pH}$ of 5.8 is required to dissociate $50 \%$ of the EGF [298-300]. Thus, at the cell surface, both ligands stimulate receptor and the ligand:receptor complex is internalized. As the complex 
moves to the early endosome, this more acidic compartment causes ligand dissociation and prevents the downstream signaling by directing the receptor to the lysosome.

This transparent presentation of the data allows us to see that carcinogenesis is a stochastic process. Much the way not every smoker develops lung cancer, not every lung cell exposed to arsenic has the same increase in TGFa or EGFR expression. The kinetic data reveal overall trends, but the timing and magnitude of TGFa expression clearly varies from sample to sample. A longer and larger analysis may be useful for making clinical predictions.

Chronic exposure of BEAS-2B cells to environmentally relevant concentrations of arsenic results in increased TGF $\alpha$ expression accompanied by elevated EGFR phosphorylation and increased cell surface EGFR, which is uniquely different from acute arsenic exposure. This study demonstrates different toxicological effects between acute and chronic arsenic exposure by highlighting their effects on EGFR activity and localization. 


\section{CHAPTER 3}

\section{CHRONIC ARSENIC EXPOSURE INCREASES EGFR-DEPENDENT CELL MOTILITY}

\section{IN BEAS-2B CELLS}

\section{Introduction}

Arsenic is an environmental contaminant that is ranked number one on the Agency for Toxic Substances and Disease Registry (ATSDR) Substance Priority List (ATSDR, 2017). Depending on the dose and duration of exposure, arsenic can have profoundly different toxicities. For instance, acute high dose arsenic exposure causes dehydration, hypotension, gastrointestinal distress (abdominal pain, vomiting, diarrhea), and renal failure [22]. In contrast, low dose chronic exposure is linked to diabetes, cardiovascular disease, dermal pathologies and respiratory diseases including lung cancer [22]. While the underlying pathophysiology associated with acute arsenic exposure is clear, the molecular changes accompanying chronic exposure have not been fully elucidated.

The lungs are one of the primary tissues damaged by chronic arsenic exposure. In studies using female mice exposed to arsenic in utero and whole-life exposure [75], whole life exposure to arsenic caused approximately six-fold increase in the incidence of lung cancer. These experimental data are supported by epidemiologic studies showing the highest incidence of lung cancer in countries that have high levels of arsenic in drinking water $[102,103,124-126,223,413]$. Despite these associations, there are no clearly defined mechanisms by which chronic arsenic exposure induces carcinogenesis. The goal of this research is to understand how chronic arsenic exposure changes lung 
cells to make them more carcinogenic. Once identified, these cellular and molecular changes can be used for the diagnosis, prognosis, and treatment of lung cancer.

BEAS-2B cells, non-malignant human lung bronchus epithelial cells immortalized by SV40 transfection, have proven to be an excellent model for arsenic-induced lung cell carcinogenesis [203, 381]. Studies from multiple labs have demonstrated that arsenic exposure (>15 weeks) can alter the cell's phenotype to having an increase in carcinogenic phenotype, including anchorage independent cell growth $[173,175,177$, $187,190-193,203,204,206]$ and increased cell motility [42, 192].

In vitro studies, using concentrations that more accurately reflect those seen in human plasma generate a more relevant model of arsenic toxicity in humans. Reports in the literature include arsenic exposures up to $60 \mu \mathrm{M}[178,179]$. For our studies, we used an arsenic concentration (100 nM) observed in the plasma of individuals that chronically consumed arsenic-contaminated drinking water [51]. Our previous study demonstrated that chronic low level of arsenic exposure increases Epidermal Growth Factor Receptor (EGFR) expression and basal activity. These changes were accompanied by increases in cell migration and TGFa secretion [42]. The EGFR is a receptor tyrosine kinase that is frequently overexpressed or hyperactivated in many cancers, including lung cancer [276, $304,305,307,309,310,394,395]$. Overexpression of the EGFR is associated with poor patient prognosis. Despite these clear links to lung cancer, how changes to the EGFR signaling axis impact lung epithelial cell biology is not fully understood.

To better understand the cellular basis for the increased cell migration and how chronic arsenic exposure impacts the EGFR signaling pathway, we combined transwell migration assays, time-lapse live cell imaging microscopy, and biochemical assays to assess EGFR-mediated signaling in BEAS-2B cells. Conditioned media from cells chronically treated with arsenite did not increase cell migration, rather, the conditioned media attenuated cell motility, suggesting the amount of secreted TGFa alone is not 
sufficient to enhance cell migration. After 24 weeks of $100 \mathrm{nM}$ arsenite exposure, we observed a two-fold increase in the cell speed, a $23 \%$ increase in cell persistence, and a $30 \%$ increase cell protrusion length as compared to passage-matched cells. The increased cell motility of chronic arsenic treated cells reverted back to the basal rate of the passage-matched cells with AG1478, an EGFR inhibitor. However, increased cell persistence and the length of cell protrusion were not AG1478-dependent. Together, these data demonstrate that chronic low level arsenite exposure increases cell motility, persistence and protrusion length.

\section{Materials and methods}

Cell culture

Human bronchial epithelial (BEAS-2B) cells were obtained from ATCC and grown in LHC-9 media (Gibco) supplemented with or without $100 \mathrm{nM}$ sodium arsenite (Fisher Scientific) on a matrix of $10 \mu \mathrm{g} / \mathrm{mL}$ of fibronectin and $35 \mu \mathrm{g} / \mathrm{mL}$ of collagen (FNC Coating Mix, AthenaES). The sodium arsenite (arsenite) concentration was based on the average blood arsenic level in people who were exposed to high levels of arsenite in drinking water [51]. Cultures were grown in $5 \% \mathrm{CO}_{2}$ at $37^{\circ} \mathrm{C}$ atmosphere. Three independent cultures of cells ( 3 with and 3 without $100 \mathrm{nM}$ sodium arsenite) were maintained separately for 24 weeks. Cells were propagated by splitting at $1 \times 10^{6}$ cells/ $10 \mathrm{~cm}$ dish every 3-4 days. Weekly, cells were frozen down at $1 \times 10^{6}$ cells/vial and stored in liquid nitrogen [42].

\section{Transwell assay}

The 8- $\mu \mathrm{m}$ polycarbonate membrane, 6.5-mm inserts (Corning, Inc., Corning, NY) were moisturized with serum-free media for 30 minutes at $37^{\circ} \mathrm{C}$. After incubation, serum-free media containing the indicated concentrations of EGF and arsenic were added in the 
lower chamber. Media from BEAS-2B cells grown in $100 \mathrm{nM}$ arsenic for 24 weeks (conditioned media) was harvested after 24 hours at $37^{\circ} \mathrm{C}$ in $5 \% \mathrm{CO}_{2}$. A density of 100,000 BEAS-2B cells were plated in the upper chamber of the insert (The cells were harvested as described above). The cells were allowed to migrate for 16 hours at $37^{\circ} \mathrm{C}$ in $5 \% \mathrm{CO}_{2}$. Migrated cells were then fixed in methanol, stained in Giemsa (3250-4, Ricca Chemical, Arlington, Texas), and counted under a microscope (TE-2000; Nikon, Tokyo, Japan) with a $20 x$ objective.

\section{Time-lapse microscopy}

A Nikon TE2000 microscope equipped with control of temperature and $\mathrm{CO}_{2}$ levels was used. BEAS-2B cells were seeded at 2,000 cells $/ \mathrm{cm}^{2}$ on an FNC-coated 6-well plate for at least $24 \mathrm{~h}$ prior to imaging. The images were obtained with a $10 \mathrm{X}$ objective every 15 minutes over a $24 \mathrm{~h}$ period for 6 positions per condition in three biological replicates. A total of 30 cells per condition were tracked for cell migration and persistence, and 108 cells per condition for protrusion lengths. The rate of cell migration and protrusion lengths were analyzed with ImageJ using Manual Tracking plugin and cell persistence was measured using the Chemotaxis and Migration Tool (Ibidi).

\section{Data Analysis}

Data were analyzed using Graphpad Prism 5.0 Software (Graphpad Software). Statistical tests are indicated in the figure legends.

\section{Results}

Chronic arsenic treatment of BEAS-2B cells increases basal and EGFR stimulated cell migration. 
In our previous study, we observed an increase in cell migration and production of TGFa from chronic arsenic exposure [42]. To determine whether the amount of secreted soluble ligands are sufficient to increase BEAS-2B cell migration, we performed a series of transwell migration assays using cells that were grown in $100 \mathrm{nM}$ arsenite for 24 weeks $(24 w)$ or passaged-matched (24PM) control cells (Fig. 12). Consistent with our previous study, chronic arsenic treatment resulted in a three-fold increase in cell migration as compared to the passage-matched cells (Fig. 12). Both cell lines were responsive to the endogenous EGFR ligand TGFa and exhibited a 2-2.5-fold increase in cell migration (Fig. 12).

Next, we measured cell migration in response to conditioned media from BEAS2B cells grown in $100 \mathrm{nM}$ arsenite for 24 weeks. Following treatment with conditioned media, cell migration was indistinguishable from the passage-matched control cells, but significantly decreased from the chronic arsenic treated cells ( $p=0.0464)$ (Fig. 12). Immuno-depletion with an anti-TGFa antibody did not significantly change cell migration from conditioned media treatment (Fig. 12). Together, these data indicate that chronic arsenic treatment enhances basal and EGFR-stimulated cell migration, but the total, secreted TGFa from the conditioned media alone is not sufficient to mediate the enhanced migration.

Chronic arsenic exposure increases the distance traveled and cell persistence.

To better understand how chronic arsenic treatment increases cell migratory ability, we used time-lapse microscopy to monitor arsenic treated and passage-matched cells (Supplemental videos 1-6). We assessed cell movement by manually tracking cell location every 15 minutes in three biological replicates (6 fields/biological replicate), and marked each track with its endpoint on the trajectory plot to measure the distance traveled (Fig. 13A). Nearly 50\% more cells traveled greater distance with chronic arsenic 


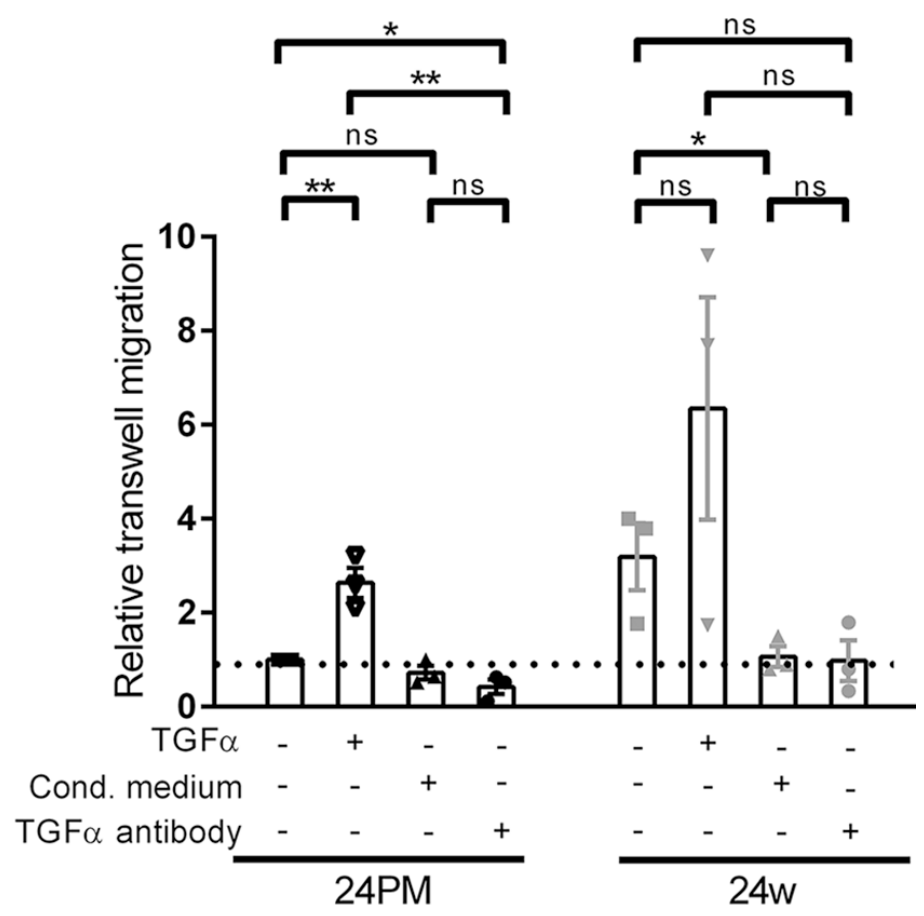

Figure 12. Chronic arsenic treatment of BEAS-2B cells increases basal and EGFR stimulated cell migration. Passage matched and 24 weeks arsenic treated cells were plated onto the upper chamber of a $0.8 \mu \mathrm{m}$ transwell. EGF-deficient (SF) media alone, SF media with $10 \mathrm{ng} / \mathrm{mL}$ TGFa, medium from chronic arsenic (24 weeks) treated cells (conditioned medium), and conditioned media incubated with TGFa neutralizing antibody were placed onto the bottom chamber and the cells were allow to migrate at $37^{\circ} \mathrm{C}$ for 16h. The cells that migrated through the transwell were fixed with the methanol and stained with Giemsa. Total 10 fields were imaged per sample to count the number of migrated cells. The numbers of migrated cells were then normalized to passage matched cells without arsenic treatment. Individual symbols represent the fold change in the number of migrated cells from each experiment $(n=3)$. Data were analyzed by oneway ANOVA (Graphpad Prism). $\left({ }^{*} p<0.05,{ }^{* *} p<0.01,{ }^{* * *} p<0.001,{ }^{* * *} p<0.0001\right)$. 

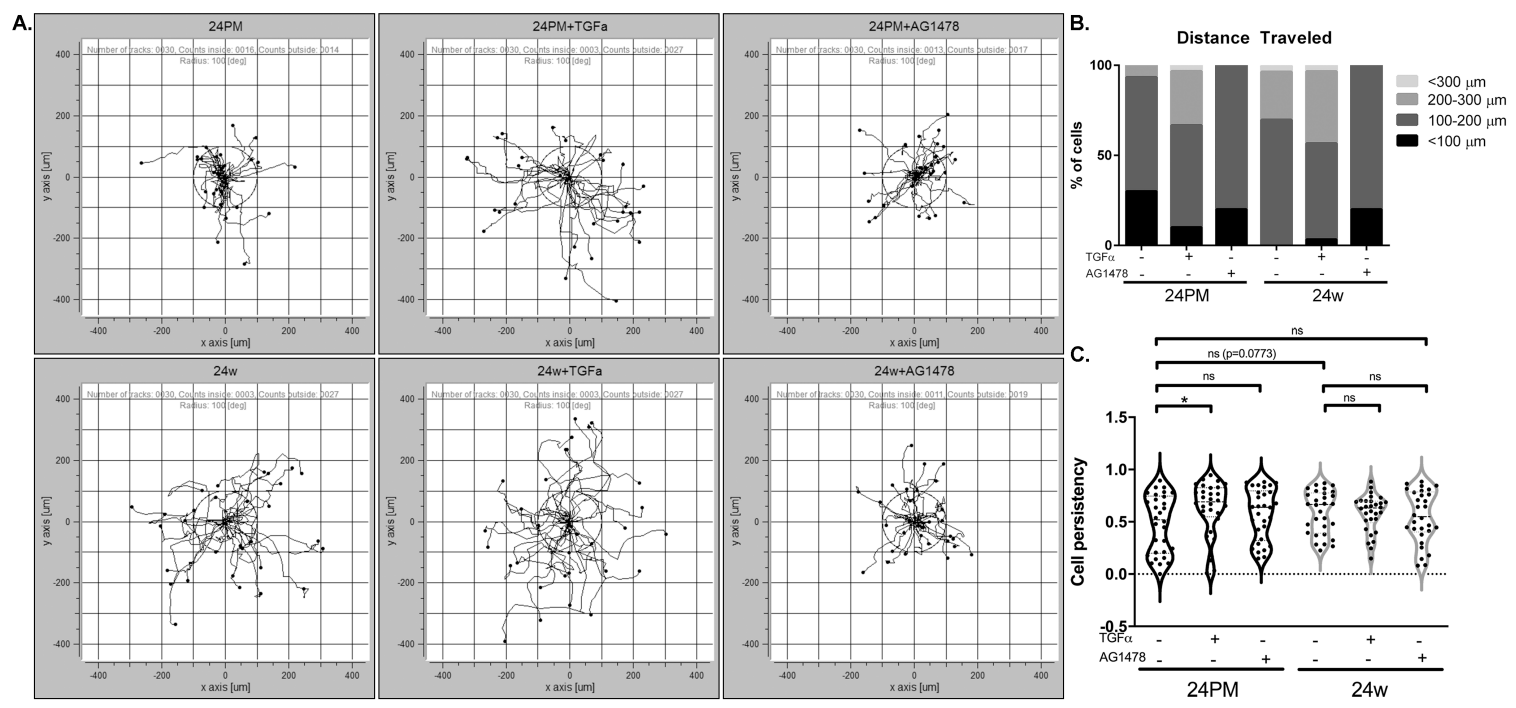

Figure 13. Chronic arsenic treatment of BEAS-2B cells increases the distance traveled and cell persistence. A. Each line represents a path of individual cell migrating from the site of its origin. The gray circle (radius of $100 \mu \mathrm{m}$ ) around the origin represents the threshold that was applied to measure the distance traveled. The cells were captured using a 10x phase-contrast objective lens and focused on the cell membrane protrusions. Six fields from each biological replicate were captured for every condition. A total of 10 cells/each of the three biological replicate were analyzed for every condition. Cell movements were manually tracked every 15 minutes for 24 hours. B. The cell distance was analyzed with Chemotaxis and Migration Tool (Ibidi). C. Data are plotted as the cell persistency of 10 cells of each biological replicate $(n=3)$. Data were analyzed by oneway ANOVA (Graphpad Prism). $\left({ }^{*} p<0.05,{ }^{* *} p<0.01,{ }^{* * *} p<0.001,{ }^{* * * *} p<0.0001\right)$. 
exposure as compared to the passage-matched cells (Fig. 13A and 13B). The passagematched cells treated with TGFa had the same number of cells as the arsenic treated cells that traveled greater than $100 \mu \mathrm{m}$ (Fig. 13A). Unlike the passage-matched cells, TGFa treatment did not affect the arsenic treated cells in distance traveled. AG1478, however, decreased the number of cells traveling greater than $100 \mu \mathrm{m}$ in chronic arsenic treated cells by approximately 30\% (Fig. 13A and 13B). Together, these data suggest that chronic arsenic exposure increases the distance traveled and it is EGFR-dependent. Another determinant of cell migration is persistence, or the sustained directionality of a cell. Enhanced cell persistence contributes to increased cell migration [414]. The closer the persistence value is to 1 , the more directionality (linearity of migration) there is. There was $23 \%$ increase in the cell persistence of chronic arsenic treated cells as compared to the passage-matched controls ( $p=0.0773)$ (Fig. 13C). Interestingly, the passage-matched cells significantly increased their persistence with TGF $\alpha$ treatment, but chronic arsenic treated cells stayed at the same level as those without TGF $\alpha$ (Fig. 13C). Treatment with AG1478 had no significant effect on cell persistence in either group (Fig. 13C).

EGFR is necessary and sufficient for increasing cell speed in chronic arsenic treated cells.

To determine whether the cell speed is consistent with the increased cell migration, we assessed the cell average velocity. Consistent with the transwell migration assays, we observed that chronic arsenic treated cells move approximately twice as fast as the untreated cells (Fig. 14A and 14B). We also examined whether the EGFR was driving the increase in cell speed, by treating cells with TGFa or AG1478, (Fig. 14A and 14B, supplemental videos 3-6). TGFa increased the average cell speed in the passagematched cells approximately two-fold (Fig. 14Aii and 14B). TGFa had a more modest 
A. Micrographs of cell motility of BEAS-2B cells
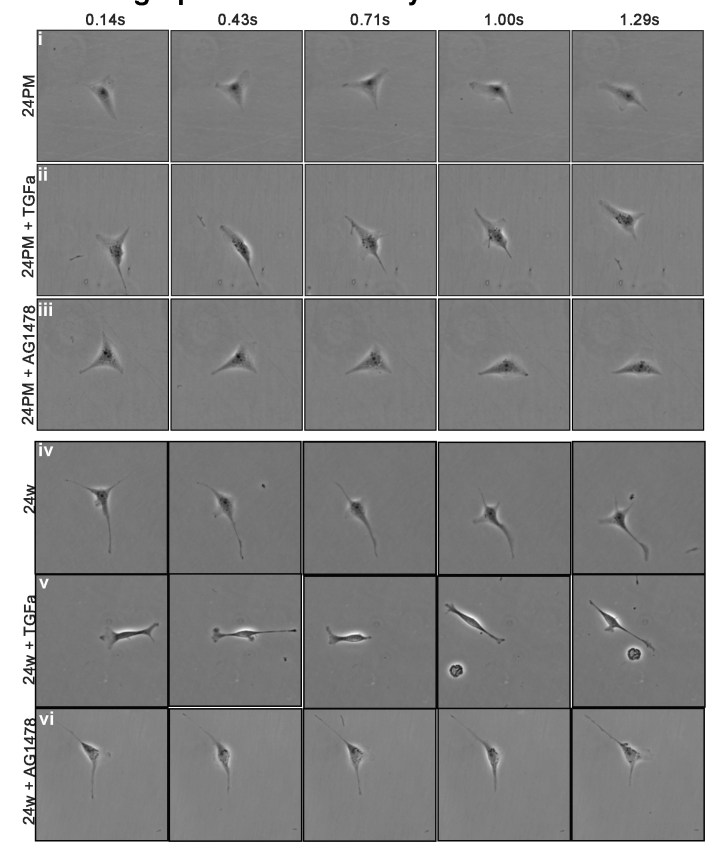

B. Quantitative analysis of cell speed

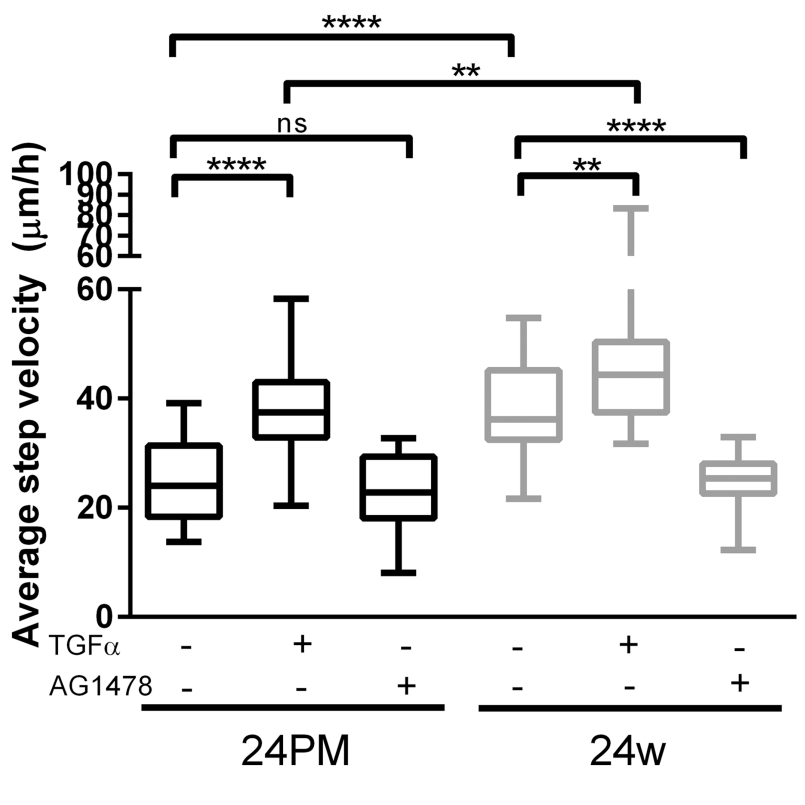

Figure 14. EGFR is necessary and sufficient for increasing cell speed in chronic arsenic treated cells. BEAS-2B cells were grown with and without $100 \mathrm{nM}$ arsenic for 24 weeks. A. Representative micrographs showing the cell motility of a single, representative BEAS-2B cells. At least after 24 hours of seeding of cells, BEAS-2B cells were treated with $10 \mathrm{ng} / \mathrm{mL}$ TGFa or $60 \mathrm{nM}$ AG1478. The cells were captured using a 10x phasecontrast objective lens and focused on the cell membrane protrusions. See videos in supplementary data. Six fields from each biological replicate were captured for every condition. A total of 10 cells/each of the three biological replicate were analyzed for every condition. Cell movements were manually tracked every 15 minutes for 24 hours. B. Images from the micrographs were quantified using NIH Image. Data are plotted as the average of velocity of 10 cells from each biological replicate $(n=3)$. Data were analyzed by one-way ANOVA (Graphpad Prism). ( ${ }^{*} p<0.05,{ }^{* *} p<0.01,{ }^{* * *} p<0.001$, $\left.{ }^{* * * *} p<0.0001\right)$. 
relative fold-increase in the velocity of the arsenic treated cells (Fig. 14Av and 14B), but an overall greater velocity. In the presence of AG1478, the velocity of both passagematched and chronic arsenic treated cells reverted to the basal migration rate of passage-matched cells (Fig. 14B).

EGFR is sufficient, but not necessary for increasing cell protrusion length in chronic arsenic treated cells.

The sparse cell plating density needed for time-lapse imaging revealed striking changes in cell morphology. During the time-lapse imaging, we noted an increase in cell protrusion length in chronic arsenic treated cells (Fig. 15A), and that was not revealed at higher cell density. Cell protrusions are membrane extensions formed by actin polymerization and are associated with an increase in cell migration $[415,416]$. We wanted to know whether chronic arsenic exposure increases cell protrusion length.

Using the individual frames from our live-cell imaging, we measured cell protrusion lengths of each biological replicate in both untreated and arsenic treated cells. Cell protrusion length was measured as the distance from the outermost portion of the cell membrane to the cell center. All cells were measured when they were at their maximal length during the 24-hour video.

We observed a $30 \%$ increase in cell protrusion length in cells chronically treated with arsenic, as compared to the passage-matched cells (Fig. 15A and 15B). TGFa significantly increased cell protrusion length in both untreated and arsenic treated cells (Fig. 15A and 15B). Unlike cell speed, there was no apparent difference in the length of cell protrusion when chronic arsenic treated cells were treated with AG1478 (Fig. 15B). 

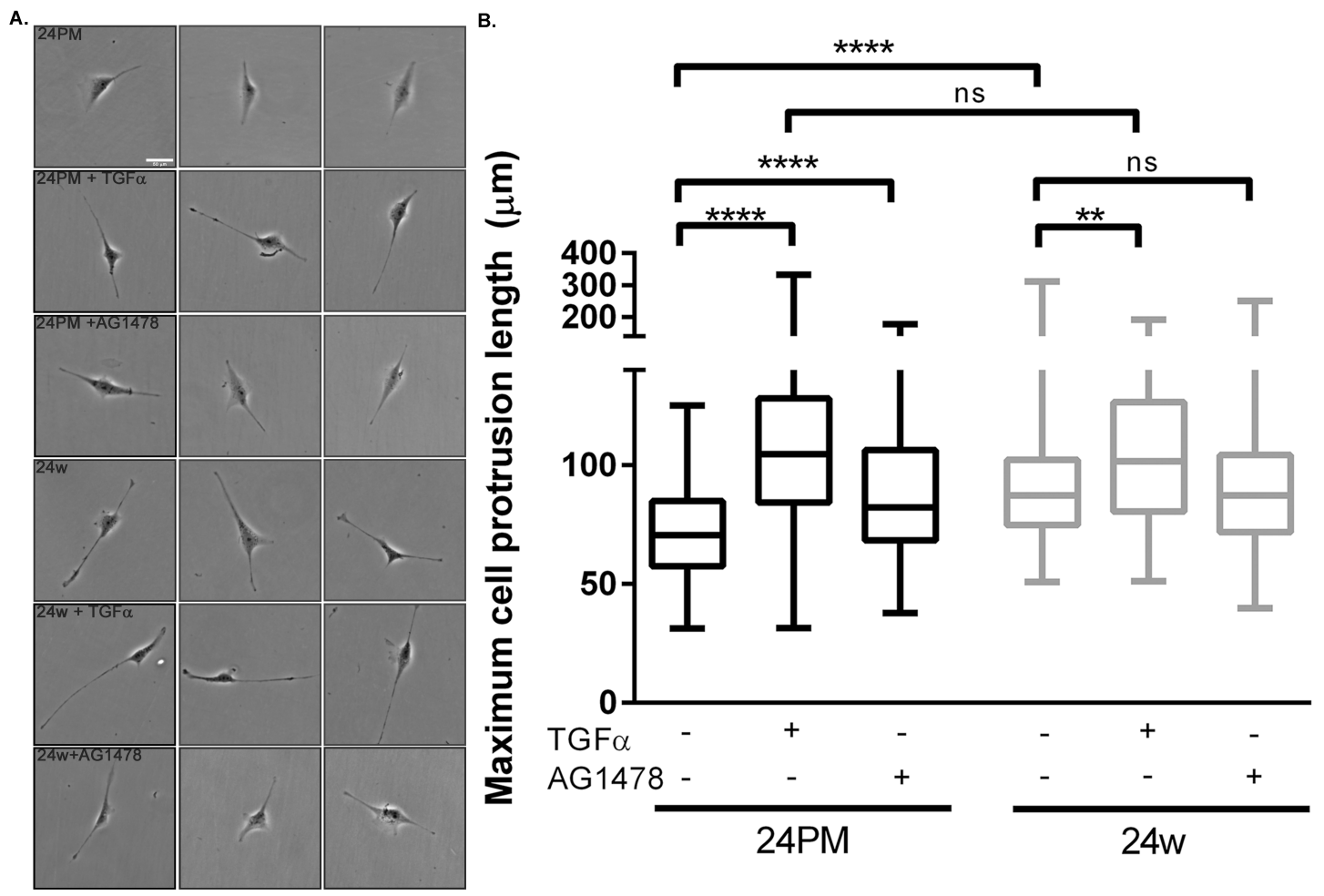

Figure 15. EGFR is sufficient, but not necessary for increasing cell protrusion length in chronic arsenic treated cells. BEAS-2B cells exposed with and without $100 \mathrm{nM}$ arsenic for 24 weeks. A. Representative micrographs showing the cell protrusions of BEAS-2B cells. The cells were captured using a 10x phase-contrast objective lens. Six fields from each biological replicate were captured for every condition. A total of 36 cells were analyzed for each of the three biological replicates for each condition. Cell protrusion length was measured as the distance from the leading edge of the cell membrane protrusion to the cell mid-body. All cells were measured when they were at their maximal length during the 24-hour video. The images were captured every 15 minutes for 24 hours. B. Data are plotted as the maximum lengths of cell protrusion of 36 cells of each biological replicate $(n=3)$ Data were analyzed by one-way ANOVA (Graphpad Prism). (* $\left.p<0.05,{ }^{* *} p<0.01,{ }^{* * *} p<0.001,{ }^{* * *} p<0.0001\right)$. 


\section{Discussion}

Arsenic is a well-established environmental contaminant that is strongly associated with the development of chronic lung diseases, including lung cancer [102, $103,123,128,130-132]$. Despite this association, there is a significant need to better understand the mechanism of arsenic-induced lung carcinogenesis and leverage these insights for developing diagnostic and therapeutic tools. In our earlier study, we observed an increase in EGFR expression and activity levels, as well as an increase in soluble TGFa secretion from chronic arsenic exposure [42]. TGFa is a unique EGFR ligand as it promotes receptor recycling and increases the steady-state levels of the EGFR. Here, we investigate whether these cellular changes are sufficient to increase cell migration.

Our transwell migration assays show that the amount of secreted TGFa in the conditioned medium is not sufficient to increase cell migration (Fig. 12). The conditioned media were unable to increase cell migration in either passage-matched or cells chronically treated with arsenic. This was not entirely unexpected because the concentrations produced (average concentration of $58 \mathrm{pg} / \mathrm{mL}$ ) [42] are approximately 400 -fold less than the $K_{D}$ for the receptor $(4.6 \mathrm{nM}$ or $25,300 \mathrm{pg} / \mathrm{mL}$ ) [404]. It is likely that TGF $\alpha$ signals in an autocrine or paracrine fashion, and collecting the media disrupts the higher local concentrations at the point of ligand production and receptor activation. However, we cannot rule out the possibility that there are other components that contribute to cell motility in chronic arsenic treated cells.

Time-lapse microscopy allowed us to measure individual cellular changes associated with increased cell migratory ability - namely, cell distance traveled, persistence, speed, and protrusion length. These parameters were enhanced in chronic arsenic treated cells, as compared to the passage-matched cells (Supplementary Videos 1-6). While the passage-matched cells increased in cell distance traveled, persistence, 
speed, and protrusion length in response to TGFa, only cell speed and protrusion lengths were enhanced with TGFa in the cells chronically treated with arsenic. This may be due to the enhanced levels of EGFR activity and the addition of more growth factor cannot further increase cell persistence, which is already near the maximal effect.

Because we observed an increase in cell invasion potential from chronic arsenic exposure, it is worth measuring these parameters on cancerous cells to compare their functional readouts to the chronic arsenic exposed cells. These findings will help us to identify possible therapeutic target to mitigate arsenic toxicity.

Interestingly, the addition of the EGFR inhibitor, AG1478, decreased the distance traveled and cell speed in cells chronically treated with arsenic, but did not have a statistical effect on persistence or protrusion lengths. While these parameters are related to cell invasion, cell protrusion length, particularly, is strongly associated with 3D invasion behaviors [417]. A study has reported that a glioblastoma cell line, U87, has the longest average protrusion length into the collagen and the highest invasion ability, as compared to the other typical glioblastoma cell lines [417]. This study highlights the importance of the cell protrusion length and its contribution to metastatic capacity. Because we have only observed a statistical effect of AG1478 on cell speed, but not on cell persistence or protrusion lengths in cells chronically treated with arsenic, one explanation is that EGFR-dependent mechanisms do participate in invasion, but additional mechanisms are present. Alternatively, chronic arsenic exposure could stimulate intrinsic reprogramming processes to allow cells to acquire enhanced persistence and cell protrusions, which are commonly observed in malignant cells [418423]. For instance, cell membrane protrusions are dependent on the Rho family of GTPases, such as Rac1 and RhoA [424-427]. Furthermore, studies have shown that arsenic increases both expression and activity levels of Rac1 [240, 428], which is known to promote actin polymerization and membrane protrusion. Thus, it is worth investigating 
how the effects of more physiologically relevant concentration of arsenic exposure might impact the Rho family of GTPases. This would help elucidate the mechanism by which chronic arsenic exposure promotes cell protrusions and persistence. Further, integrin receptor signaling is associated with cytoskeletal rearrangement $[429,430]$, and there is a paucity of research studying the association between chronic arsenic exposure and integrin receptor signaling. Particularly, fibronectin receptor is known to be involved in polarized cell protrusions [431]. Because we observed EGFR-independent mechanisms of chronic arsenic exposure-induced cell persistence and protrusions, it is worth investigating how a chronic low level of arsenic exposure impacts integrin receptors, specifically fibronectin receptor, and exploring possible arsenic-induced crosstalk between fibronectin receptor and EGFR to enhance cell migratory ability.

\section{Conclusion}

Despite a clear association between chronic arsenic exposure and lung cancer, little is understood about the molecular changes that lead to carcinogenesis. To better understand the cellular basis, we assessed EGFR dependency in cell speed, persistence and protrusion length in chronic arsenic treated BEAS-2B cells. We observed that chronic arsenic exposure increases cell speed in an EGFR-dependent manner, but increased cell persistence and protrusion lengths are not dependent on EGFR. Together these changes provide a better understanding of how non-malignant human lung epithelial cells acquire cancer-like phenotypes from chronic arsenic exposure. We anticipate that this study opens up new avenues for identifying potential therapeutic targets for arsenic-induced lung diseases. 


\section{CHAPTER 4}

\section{DISCUSSION AND FUTURE DIRECTIONS}

\section{A. Restatement of Research Goals}

There is a strong association between chronic arsenic exposure and EGFR overexpression, however the exact mechanism of chronic arsenic exposure-induced EGFR overexpression, as well as of chronic arsenic exposure-induced lung cancer development still remain elusive. This work provides novel mechanisms to chronic arsenic-induced EGFR overexpression, as well as functional effects of chronic arsenic exposure that contributes to lung cancer development. Further, this study differentiates the impact of acute and chronic arsenic in human lung epithelial cells.

\section{B. Summary of Findings}

To determine whether chronic exposure to an environmentally relevant level of arsenic alters EGFR expression, we performed immunoblot. Both EGFR expression and its activity levels were measured in acute and chronic arsenic exposure conditions. Unlike acute arsenic exposure, chronic exposure increased both expression and activity levels of EGFR. The enhanced EGFR activity was supported by increased cell migratory ability. We also performed flow cytometry to identify the localization of EGFR. We observed an increase in the cell surface level of EGFR from chronic arsenic exposure. To understand the biochemistry behind this phenomenon, we performed RT-qPCR to measure mRNA levels of a subset of EGFR ligands in both acute and chronic arsenic conditions. We observed a time-dependent increase in TGFa mRNA levels from chronic arsenic exposure, but from acute exposure, there was a significant increase in BTC. 
These data further highlight different cellular impact of acute and chronic arsenic exposures and support different toxicological effects of arsenic in humans (Table 1). To determine whether protein levels are consistent with the mRNA level, we performed ELISA and observed an increased secretion of TGFa from chronic arsenic exposure. In addition to identifying chronic arsenic exposure-induced secretion of TGFa, we wanted to investigate if the amount of secreted TGFa from chronic arsenic exposure was sufficient to induce cell migration. First, we performed a series of transwell migration assays using conditioned media. We observed that the amount of secreted TGFa is not sufficient to increase cell migration. Next, we wanted to understand of the cellular level of the increased cell migratory ability from chronic arsenic exposure. We used time-lapse live cell imaging microscopy to measure the distance traveled, cell persistence, speed, and cell protrusion length. Consistent with our previous study, as well as our transwell migration assay, we observed an increase in the distance traveled and average cell velocity in chronic arsenic treated cells in an EGFR-dependent manner. Therefore, EGFR is necessary and sufficient for increasing cell speed in chronic arsenic treated cells. Because cell persistence contributes to increased cell migration [414], we measured cell persistence in chronic arsenic treated cells. We hypothesized an increase in persistence in chronic arsenic treated cells, because faster cells turn less as speed stabilizes cell directionality. Expectedly, we observed an increase in cell persistence in chronic arsenic treated cells, but it was not EGFR-dependent, as neither TGFa nor AG1478 was able to affect the cell persistence in chronic arsenic treated cells. During time-lapse imaging, we noted long cell protrusions in chronic arsenic treated cells. Cell membrane protrusions are strongly associated with cell migration $[415,416]$, as well as 3D cell invasion [417]. Together, these data show that chronic arsenic increases cell migration in both EGFR-dependent and -independent mechanisms. A schematic diagram that summarizes the project is shown in Figure 16. 


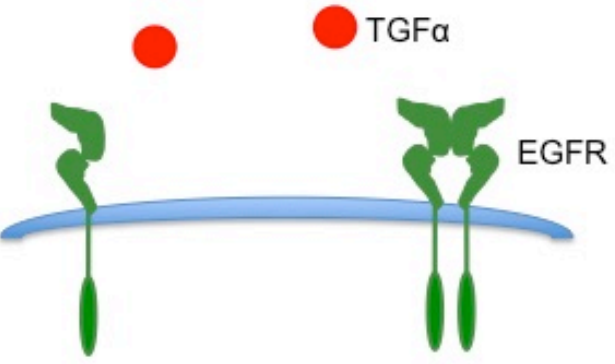

Normal Condition

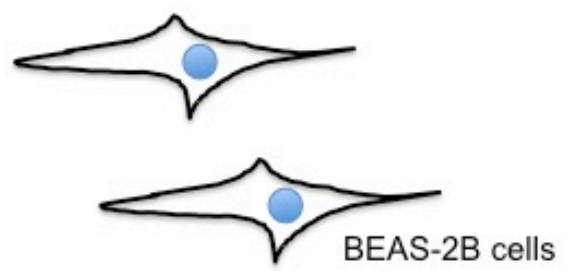

Chronic arsenic exposure

Aim 1 \&2

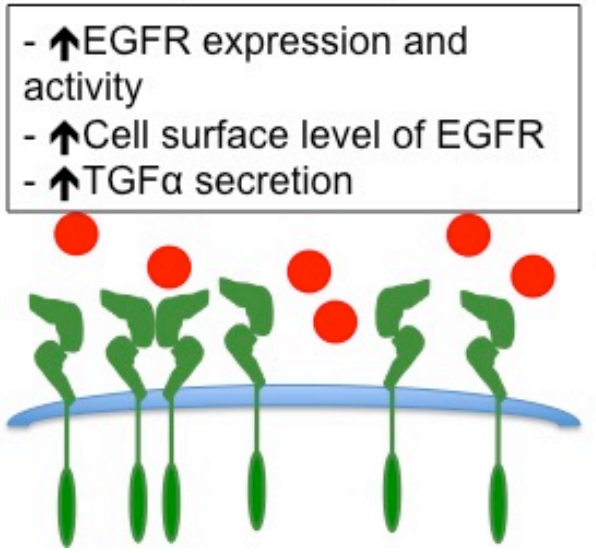

Aim 3

- 个Cell migration

- $\boldsymbol{\uparrow}$ Cell average velocity in an EGFRdependent manner

- $\uparrow$ Cell persistence and cell protrusion

length in an EGFR-independent manner

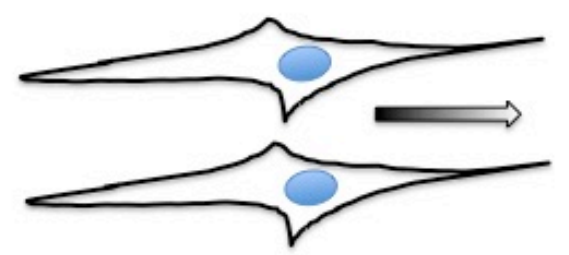

Figure 16. A schematic diagram that summarizes the impact of chronic arsenic on the EGFR signaling axis and on cell migration. 


\section{Significance of Findings}

There is a direct association between arsenic in drinking water and cancer development, including non-small cell lung cancer (NSCLC). Proposed mechanisms of arsenic carcinogenicity include, oxidative stress [217-223], miRNA expression [225, 228, 229], aneuploidy [235], and activation of oncogenic pathways [172, 236-252]. However, a clear arsenic-induced carcinogenic mechanism still remains elusive. Both a previous study and our study show that acute arsenic exposure (1-10 $\mu \mathrm{M})$ induces overexpression of the EGFR $[42,277]$. However, how chronic arsenic exposure affects the EGFR expression and its signaling axis remains unclear.

This study is significant because it broadened our understanding of the effect of chronic arsenic exposure on the EGFR signaling axis, contributing to overexpression of EGFR. We observed that chronic arsenic exposure increases TGFa expression level, resulting in an increase in steady state level of EGFR. These findings suggest that TGFa level can be served as a biomarker for the arsenic exposure-induced cancer development. Because an increase in TGFa level is not specific to lung cancer, further studies are needed to identify cancer type-specific biomarker. These findings also suggested that acute and chronic arsenic exposure act differently on the EGFR signaling axis, supporting different toxicological effects observed in humans between acute and chronic exposure. Further, we assessed the functional effects in cells chronically treated with arsenic using a time-lapse microscopy. We observed that both EGFR-dependent and -independent mechanisms contribute to an increase in cell invasion potential from chronic arsenic exposure. Together, the findings reported in this dissertation are significant because they help develop strategies to mitigate the effect of arsenic toxicity, which align with the National Institute of Environmental Health Sciences mission of discovering the impact of environmental toxicants on people to promote healthier lives. 


\section{Strengths and Weaknesses}

\section{i. Strengths}

A major strength of this work is in its use of a physiologically relevant level of arsenic and exposure time. There are a variety of cell lines, arsenic concentrations and exposure times used in many in vitro studies. The variations in arsenic concentrations make direct comparisons challenging; however, the majority of these studies reflect the differences in the level of arsenic exposure across the globe. The range of concentrations is consistent with the notion that there is no "correct" arsenic concentration or consensus in the field. However we wanted to generate the most biologically meaningful in vitro studies. The arsenic concentration of $100 \mathrm{nM}$ reflects the average blood arsenic level in people who were exposed to high levels of arsenic in drinking water [51]. Also, deleterious effects of arsenic are highly dependent not only on the dose but also on duration of exposure, as acute and chronic toxicities present differently. To mimic human chronic exposure to arsenic, we treated BEAS-2B cells for 6 months, as chronic exposure is defined as an exposure lasting 6 months to a lifetime, according to the EPA Terminology Services [20]. Also, BEAS-2B cells require specific growth medium and coated plates. Many studies, however, have used incorrect media (added FBS), and/or the cells were not cultured in collagen-coated plates. All these factors are known to alter cell morphology, increase mesenchymal associated gene expression, decrease in epithelial associated gene expression, and increase sensitivity to arsenic $[432,433]$. Thus, the cells with these altered characteristics can lead to erroneous data to assess and predict toxicological response due to changes in sensitivity of the cells. We followed the ATCC recommended guidelines and protocols for choosing a proper cell culture media and growth conditions for BEAS-2B cells and ensured by STR mapping after completion of 24 weeks in all three biological replicates. 
Another strength of this work is we were able to assess differential impacts of acute and chronic arsenic exposure in the EGFR signaling axis, as well as cellular changes (cell motility, persistence, protrusion length) in BEAS-2B cells chronically treated with arsenic. There are a scarce number of studies that analyze both acute and chronic arsenic exposures. Our study supports different toxicological effects observed in humans from acute and chronic arsenic exposure and suggests possible differential mechanistic pathways of acute and chronic arsenic exposures.

Also, we observed an increased secretion of EGFR endogenous ligand TGFa from chronic arsenic exposure, which supports a study that observed overexpression of both EGFR and TGFa level in NSCLC patients [305]. We anticipate that this study will contribute to identifying potential therapeutic targets for arsenic-induced lung diseases. ii. Weaknesses

One of the few limitations of this work is in its use of one cell line and not using any animal models. At present, a number of journals require using multiple cell lines to support the scientific findings. Using multiple cell lines will further strengthen the value of toxicological studies in vitro and bolster animal and clinical studies. Animal models are widely used in toxicological studies as the target sites of arsenic carcinogenetic effects in animals are concordant with most of the human targets of arsenic and reflect human toxicological responses. Further, due to the nature of toxicokinetics, the cell culture responds differently from the human organism even with the same concentration of arsenic. However, it is important to note that in vitro models provide fundamental platform for animal studies and tools for elucidating the molecular mechanisms underlying arsenic toxicity and carcinogenesis.

Lack of carcinogenicity assessment is another weakness of this work. Multiple labs perform anchorage-independent assay to assess carcinogenicity of arsenic treated cells. The soft agar assay is commonly used to monitor anchorage-independent growth 
of cells. We have performed soft agar assay and we used B30TIC cells, a tumor cell line for epithelial cells, as our positive control. We observed colony formation in B30TIC cells, however, we were not able to observe any colony formation even after 29 weeks of arsenic treatment in BEAS-2B cells. Nonetheless, there are several studies that observe transformation of BEAS-2B cells from arsenic exposure. Though many studies do not use a proper cell culture media and follow the ATCC recommended growth conditions for BEAS-2B, there are a few studies that used appropriate media, as well as coating condition for BEAS-2B cells and have successfully transformed BEAS-2B cells with chronic arsenic exposure, thus it is crucial that this work be repeated. Alternatively, xenograft models could have been used to assess carcinogenicity of chronic arsenic treated cells to strengthen our findings.

An inherent limitation of in vitro experiments, when studying arsenic toxicological effects, is that not all cells receive the same level of arsenic-induced damages. As the cells divide, more damaged cells proliferate faster and tend to overcome the host's regulatory mechanism, which results in selection. Therefore, the chronic arsenic treated cells in our study may not represent the whole population of cells that were initially exposed to arsenic, but a subpopulation of cells that had the most damage from arsenic exposure and survived the host's regulatory mechanism.

\section{E. Future Directions}

In our study, we observed overexpression of EGFR from chronic arsenic exposure and the overexpression of EGFR is widely used as a biomarker for a variety of diseases, including lung cancer. However, there is a paucity of research identifying biomarkers for early and accurate diagnosis. For future study, I am specifically interested in assessing molecular epidemiologic mechanistic pathway markers for environmental toxicants-induced adverse effects on fetal growth and child neurodevelopment. 
Methylation steps have been characterized as a critical arsenic metabolism process. Because methylation process is important in elimination of arsenic from the systemic circulation, it is easy to incorrectly assume that methylation is a detoxification process of arsenic as it enhances excretion of arsenic. However, all arsenic metabolites are toxic to different degrees [59, 60,68,69]. High ratios of MMA/DMA are indicators of a reduction in arsenic methylation [434]. A study has shown a strong inverse relationship between urinary MMA levels and gestational age, birth weight, and newborn length [434]. However, whether these observed differences in gestational age, birth weight, and newborn length affect the later life health had remained elusive, until a recent casecontrol study uncovered arsenic methylation capacity is associated with developmental delays [435]. Further, reduction in arsenic methylation capacity is associated with arsenic-induced ROS generation and oxidative DNA damage. In a recent study, there were increased levels of 8-nitroguanine not only in women who were exposed to arsenic during pregnancy, but also in newborns and in children through their early life [436]. Delineating a direct role of arsenic-induced ROS generation in child development and assessing associations between newborns' arsenic methylation capacity and oxidative DNA damage would help identify potential biomarkers that would allow early prediction of developmental delays and children's health. Interestingly, a cohort study in Mexico observed pregnant women with higher DMA levels (88\%) as compared to general populations exposed to arsenic around the world (60-80\%) $[434,437,438]$. Because a high ratio of DMA/MMA is usually indicative of increased arsenic methylation capacity, these observed high levels of DMA might have a protective effect for both mother and fetus. Therefore, it is worth investigating the inherent differences in population characteristics, such as genetic polymorphisms and nutritional factors.

Because arsenic targets many different signaling pathways, there are many proteins that are strongly associated with arsenic exposure that can be bio-monitored for 
early diagnosis. Aquaglyceroporins (AQP) are transmembrane channel proteins involved in transferring small solutes, such as arsenite. A study has shown an increase in AQP9 expression from arsenic exposure and its association with lower birth weight [439]. Because AQP9 serves as an arsenic transporter, it is presumed that increased AQP9 increases arsenic uptake, resulting in deleterious effects in fetal growth. However the direct relationship still remains unclear, and there are other small solutes that AQP9 transfers, such as glycerol. Thus, it would be important to identify biomarkers that are exclusively induced in response to arsenic exposure.

The original goal of this research was focused on elucidating the effects of chronic arsenic exposure in EGFR signaling axis. In the process of pursuing this question, we have uncovered possible mechanisms by which chronic arsenite exposure acts to increase EGFR expression, as well as its activity, and to increase cell migratory ability. There are several proposed mechanisms for chronic arsenic-induced lung cancer development. But the clear mechanism still remains elusive. In this study, we demonstrate possible different mechanistic pathways between acute and chronic arsenic exposure and assessments of the cellular changes in lung cells chronically exposed to arsenic. For future work, we will leverage these insights to identify therapeutic targets and biomarkers to enhance current therapy. 


\section{REFERENCES}

1. ATSDR, Toxicological Profile for Arsenic. 2007.

2. IARC, Overall Evaluations of Carcinogenicity: an updating of IARC Monographs Volumes 1 to 42. IARC Monogr Eval Carcinog Risks Hum Suppl, 1987a(7): p. 1440.

3. IARC, Silica and Some Silicates. IARC Monogr Eval Carcinog Risk Chem Hum, 1987b(42): p. 1-239.

4. IARC, Monographs on the Evaluation of Carcinogenic Risk of Chemicals to Man, Vol. 2, Some Inorganic and Organometallic Compounds. 1973, Lyon. p. 48-73.

5. $\quad$ EPA. Drinking Water Arsenic Rule History. 2001.

6. George, C.M., et al., Arsenic exposure in drinking water: an unrecognized health threat in Peru. Bull World Health Organ, 2014. 92(8): p. 565-72.

7. Haller, J.S., Therapeutic mule: the use of arsenic in the nineteenth century materia medica. Pharm Hist, 1975. 17(3): p. 87-100.

8. Waxman, S. and K.C. Anderson, History of the development of arsenic derivatives in cancer therapy. Oncologist, 2001. 6 Suppl 2: p. 3-10.

9. Cutler, E., Bradford, E., Action of Iron, Cod Liver Oil and Arsenic on Globular Richness of the Blood. Am J Med Sci, 1878(75): p. 74-84.

10. Cohen, M.H., et al., Drug approval summaries: arsenic trioxide, tamoxifen citrate, anastrazole, paclitaxel, bexarotene. Oncologist, 2001. 6(1): p. 4-11.

11. Murgo, A.J., Clinical trials of arsenic trioxide in hematologic and solid tumors: overview of the National Cancer Institute Cooperative Research and Development Studies. Oncologist, 2001. 6 Suppl 2: p. 22-8.

12. Sekeres, M.A., New data with arsenic trioxide in leukemias and myelodysplastic syndromes. Clin Lymphoma Myeloma, 2007. 8 Suppl 1: p. S7-S12.

13. Hughes, M.F., et al., Arsenic exposure and toxicology: a historical perspective. Toxicol Sci, 2011. 123(2): p. 305-32.

14. Burns, F.J., et al., Arsenic-induced enhancement of ultraviolet radiation carcinogenesis in mouse skin: a dose-response study. Environ Health Perspect, 2004. 112(5): p. 599-603.

15. Rossman, T.G., A.N. Uddin, and F.J. Burns, Evidence that arsenite acts as a cocarcinogen in skin cancer. Toxicol Appl Pharmacol, 2004. 198(3): p. 394-404.

16. Rossman, T.G., et al., Arsenite is a cocarcinogen with solar ultraviolet radiation for mouse skin: an animal model for arsenic carcinogenesis. Toxicol Appl Pharmacol, 2001. 176(1): p. 64-71.

17. Rossman, T.G., et al., Arsenite cocarcinogenesis: an animal model derived from genetic toxicology studies. Environ Health Perspect, 2002. 110 Suppl 5: p. 74952.

18. Wang, W., et al., Experimental study on antitumor effect of arsenic trioxide in combination with cisplatin or doxorubicin on hepatocellular carcinoma. World $\mathrm{J}$ Gastroenterol, 2001. 7(5): p. 702-5.

19. Muenyi, C.S., et al., Sodium arsenite +/- hyperthermia sensitizes p53-expressing human ovarian cancer cells to cisplatin by modulating platinum-DNA damage responses. Toxicol Sci, 2012. 127(1): p. 139-49. 
20. EPA. Terminology Services (TS). Available from:

https://ofmpub.epa.gov/sor_internet/registry/termreg/searchandretrieve/t ermsandacronyms $/$ search.do?search=\&term=chronic\&matchCriteria=Contai ns\&checkedAcronym=true\&checkedTerm=true\&hasDefinitions=false $\% 23$ for mTop.

21. W.H. De Jong, J.W.C., R.E. Geertsma, In vivo and in vitro testing for the biological safety evaluation of biomaterials and medical devices. Woodhead Publishing Series in Biomaterials. Vol. 7. 2012: Woodhead Publishing Limited.

22. Saha, J.C., Dikshit, A.K., Bandyopadhyay, M., Saha, K.C., A Review of Arsenic Poisoning and Its Effects on Human Health. 2014.

23. Buchet, J.P., R. Lauwerys, and H. Roels, Comparison of the urinary excretion of arsenic metabolites after a single oral dose of sodium arsenite,

monomethylarsonate, or dimethylarsinate in man. Int Arch Occup Environ Health, 1981. 48(1): p. 71-9.

24. Ratnaike, R.N., Acute and chronic arsenic toxicity. Postgrad Med J, 2003. 79(933): p. 391-6.

25. Shen, S., et al., Arsenic binding to proteins. Chem Rev, 2013. 113(10): p. 776992.

26. Saha, K.C., Melanokeratosis from arsenic contaminated tubewell water. Indian J Dermatol, 1984. 29(4): p. 37-46.

27. Smith, A.H., E.O. Lingas, and M. Rahman, Contamination of drinking-water by arsenic in Bangladesh: a public health emergency. Bull World Health Organ, 2000. 78(9): p. 1093-103.

28. Tanaka, K., et al., Cysteine residues in the organic anion transporter mOAT1. Biochem J, 2004. 380(Pt 1): p. 283-7.

29. Xia, X., et al., Cys351 and Cys361 of the Na+/glucose cotransporter are important for both function and cell-surface expression. Arch Biochem Biophys, 2005. 438(1): p. 63-9.

30. Curry, A.S. and C.A. Pounds, Arsenic in hair. J Forensic Sci Soc, 1977. 17(1): p. 37-44.

31. Hostynek, J.J., et al., Metals and the skin. Crit Rev Toxicol, 1993. 23(2): p. 171235.

32. Valentine, J.L., H.K. Kang, and G. Spivey, Arsenic levels in human blood, urine, and hair in response to exposure via drinking water. Environ Res, 1979. 20(1): p. 24-32.

33. Olguin, A., et al., Arsenic levels in blood, urine, hair and nails from a chronically exposed human population. Proc West Pharmacol Soc, 1983. 26: p. 175-7.

34. Narang, A.P., L.S. Chawla, and S.B. Khurana, Levels of arsenic in Indian opium eaters. Drug Alcohol Depend, 1987. 20(2): p. 149-53.

35. Takagi, Y., et al., Survey of trace elements in human nails: an international comparison. Bull Environ Contam Toxicol, 1988. 41(5): p. 690-5.

36. Koons, R.D. and C.A. Peters, Axial distribution of arsenic in individual human hairs by solid sampling graphite furnace AAS. J Anal Toxicol, 1994. 18(1): p. 3640.

37. Wolfsperger, M., et al., Heavy metals in human hair samples from Austria and Italy: influence of sex and smoking habits. Sci Total Environ, 1994. 156(3): p. 235-42.

38. Raie, R.M., Regional variation in $\mathrm{As}, \mathrm{Cu}, \mathrm{Hg}$, and $\mathrm{Se}$ and interaction between them. Ecotoxicol Environ Saf, 1996. 35(3): p. 248-52. 
39. Das, D., et al., Arsenic in ground water in six districts of West bengal, India: the biggest arsenic calamity in the world. Part 2. Arsenic concentration in drinking water, hair, nails, urine, skin-scale and liver tissue (biopsy) of the affected people. Analyst, 1995. 120(3): p. 917-24.

40. Guha Mazumder, D.N., Chronic arsenic toxicity \& human health. Indian J Med Res, 2008. 128(4): p. 436-47.

41. Jaishankar, M., et al., Toxicity, mechanism and health effects of some heavy metals. Interdiscip Toxicol, 2014. 7(2): p. 60-72.

42. Kim, C., J.C. States, and B.P. Ceresa, Chronic and acute arsenic exposure enhance EGFR expression via distinct molecular mechanisms. Toxicol In Vitro, 2020. 67: p. 104925.

43. FDA, A Quantitative Assessment of Inorganic Arsenic in Apple Juice. 2013.

44. Zaldivar, R., L. Prunes, and G.L. Ghai, Arsenic dose in patients with cutaneous carcinomata and hepatic hemangio-endothelioma after environmental and occupational exposure. Arch Toxicol, 1981. 47(2): p. 145-54.

45. Marshall, G., et al., Fifty-year study of lung and bladder cancer mortality in Chile related to arsenic in drinking water. J Natl Cancer Inst, 2007. 99(12): p. 920-8.

46. Liu-Mares, W., et al., Pancreatic cancer clusters and arsenic-contaminated drinking water wells in Florida. BMC Cancer, 2013. 13: p. 111.

47. George, C.M., et al., Reverse osmosis filter use and high arsenic levels in private well water. Arch Environ Occup Health, 2006. 61(4): p. 171-5.

48. Knobeloch, L.M., K.M. Zierold, and H.A. Anderson, Association of arseniccontaminated drinking-water with prevalence of skin cancer in Wisconsin's Fox River Valley. J Health Popul Nutr, 2006. 24(2): p. 206-13.

49. Hutson, S.S., Barber, N.L., Kenny, J. F., Linsey, K. S., Lumia, D. S., Maupin, M. A., Estimated Use of Water in the United States in 2000. USGS Circular 1268, 2004.

50. States, J.C., et al., Arsenic toxicology: translating between experimental models and human pathology. Environ Health Perspect, 2011. 119(10): p. 1356-63.

51. $\mathrm{Pi}, \mathrm{J}$., et al., Decreased serum concentrations of nitric oxide metabolites among Chinese in an endemic area of chronic arsenic poisoning in inner Mongolia. Free Radic Biol Med, 2000. 28(7): p. 1137-42.

52. Challenger, F., Biological methylation. Sci Prog, 1947. 35(139): p. 396-416.

53. Challenger, F. and P.T. Charlton, Studies on biological methylation; the fission of the mono- and di-sulphide links by moulds. J Chem Soc, 1947. 169: p. 424-9.

54. Vahter, M. and E. Marafante, Reduction and binding of arsenate in marmoset monkeys. Arch Toxicol, 1985. 57(2): p. 119-24.

55. Marafante, E., M. Vahter, and J. Envall, The role of the methylation in the detoxication of arsenate in the rabbit. Chem Biol Interact, 1985. 56(2-3): p. 22538.

56. Thomas, D.J., and Rosen, B. P., Arsenic methyltransferases, in Encyclopedia of Metalloproteins, R.H. Kretsinger, Uversky, V. N., and Permyakov, E. A., Editor. 2013, Springer: New York, New York. p. 140-145.

57. Hayakawa, T., et al., A new metabolic pathway of arsenite: arsenic-glutathione complexes are substrates for human arsenic methyltransferase Cyt19. Arch Toxicol, 2005. 79(4): p. 183-91.

58. Garbinski, L.D., B.P. Rosen, and J. Chen, Pathways of arsenic uptake and efflux. Environ Int, 2019. 126: p. 585-597.

59. Styblo, M., et al., Comparative toxicity of trivalent and pentavalent inorganic and methylated arsenicals in rat and human cells. Arch Toxicol, 2000. 74(6): p. 28999. 
60. Mass, M.J., et al., Methylated trivalent arsenic species are genotoxic. Chem Res Toxicol, 2001. 14(4): p. 355-61.

61. Hirano, S., et al., Difference in uptake and toxicity of trivalent and pentavalent inorganic arsenic in rat heart microvessel endothelial cells. Arch Toxicol, 2003. 77(6): p. 305-12.

62. Vahter, M., et al., $A$ unique metabolism of inorganic arsenic in native Andean women. Eur J Pharmacol, 1995. 293(4): p. 455-62.

63. Hopenhayn-Rich, C., et al., Methylation study of a population environmentally exposed to arsenic in drinking water. Environ Health Perspect, 1996. 104(6): p. 620-8.

64. Chiou, H.Y., et al., Arsenic methylation capacity, body retention, and null genotypes of glutathione S-transferase M1 and T1 among current arsenicexposed residents in Taiwan. Mutat Res, 1997. 386(3): p. 197-207.

65. Schlawicke Engstrom, K., et al., Genetic polymorphisms influencing arsenic metabolism: evidence from Argentina. Environ Health Perspect, 2007. 115(4): p. 599-605.

66. Li, J., et al., Nonsynonymous Polymorphisms in the Human AS3MT Arsenic Methylation Gene: Implications for Arsenic Toxicity. Chem Res Toxicol, 2017. 30(7): p. 1481-1491.

67. Apata, M., et al., Human adaptation to arsenic in Andean populations of the Atacama Desert. Am J Phys Anthropol, 2017. 163(1): p. 192-199.

68. Naranmandura, $\mathrm{H}$., et al., Comparative toxicity of arsenic metabolites in human bladder cancer EJ-1 cells. Chem Res Toxicol, 2011. 24(9): p. 1586-96.

69. Petrick, J.S., et al., Monomethylarsonous acid (MMA(III)) is more toxic than arsenite in Chang human hepatocytes. Toxicol Appl Pharmacol, 2000. 163(2): p. 203-7.

70. Rahman, M.M., J.C. Ng, and R. Naidu, Chronic exposure of arsenic via drinking water and its adverse health impacts on humans. Environ Geochem Health, 2009. 31 Suppl 1: p. 189-200.

71. Beane Freeman, L.E., et al., Toenail arsenic content and cutaneous melanoma in lowa. Am J Epidemiol, 2004. 160(7): p. 679-87.

72. Karagas, M.R., et al., Drinking Water Arsenic Contamination, Skin Lesions, and Malignancies: A Systematic Review of the Global Evidence. Curr Environ Health Rep, 2015. 2(1): p. 52-68.

73. Smith, A.H., et al., Increased mortality from lung cancer and bronchiectasis in young adults after exposure to arsenic in utero and in early childhood. Environ Health Perspect, 2006. 114(8): p. 1293-6.

74. Tokar, E.J., W. Qu, and M.P. Waalkes, Arsenic, stem cells, and the developmental basis of adult cancer. Toxicol Sci, 2011. 120 Suppl 1: p. S192203.

75. Tokar, E.J., et al., Carcinogenic effects of "whole-life" exposure to inorganic arsenic in CD1 mice. Toxicol Sci, 2011. 119(1): p. 73-83.

76. Tokar, E.J., et al., Chronic exposure of renal stem cells to inorganic arsenic induces a cancer phenotype. Chem Res Toxicol, 2013. 26(1): p. 96-105.

77. Waalkes, M.P., et al., Lung tumors in mice induced by "whole-life" inorganic arsenic exposure at human-relevant doses. Arch Toxicol, 2014. 88(8): p. 161929.

78. Person, R.J., et al., Chronic inorganic arsenic exposure in vitro induces a cancer cell phenotype in human peripheral lung epithelial cells. Toxicol Appl Pharmacol, 2015. 286(1): p. 36-43. 
79. Luo, F.J., Z.D. Luo, and L. Ma, [A study on the relationship between drinking water with high arsenic content and incidence of malignant tumour in Heihe Village, western part of Huhehot, Inner Mongolia]. Zhonghua Liu Xing Bing Xue Za Zhi, 1995. 16(5): p. 289-91.

80. Hopenhayn-Rich, C., M.L. Biggs, and A.H. Smith, Lung and kidney cancer mortality associated with arsenic in drinking water in Cordoba, Argentina. Int $\mathrm{J}$ Epidemiol, 1998. 27(4): p. 561-9.

81. States, J.C., et al., Arsenic and cardiovascular disease. Toxicol Sci, 2009. 107(2): p. 312-23.

82. Simeonova, P.P., et al., Arsenic exposure accelerates atherogenesis in apolipoprotein E(-/-) mice. Environ Health Perspect, 2003. 111(14): p. 1744-8.

83. Bunderson, M., et al., Arsenic exposure exacerbates atherosclerotic plaque formation and increases nitrotyrosine and leukotriene biosynthesis. Toxicol Appl Pharmacol, 2004. 201(1): p. 32-9.

84. Moon, K., E. Guallar, and A. Navas-Acien, Arsenic exposure and cardiovascular disease: an updated systematic review. Curr Atheroscler Rep, 2012. 14(6): p. 542-55.

85. Das, N., et al., Arsenic exposure through drinking water increases the risk of liver and cardiovascular diseases in the population of West Bengal, India. BMC Public Health, 2012. 12: p. 639.

86. Mazumder, D.N., Effect of chronic intake of arsenic-contaminated water on liver. Toxicol Appl Pharmacol, 2005. 206(2): p. 169-75.

87. Nishikawa, T., et al., Promoting effects of monomethylarsonic acid, dimethylarsinic acid and trimethylarsine oxide on induction of rat liver preneoplastic glutathione S-transferase placental form positive foci: a possible reactive oxygen species mechanism. Int J Cancer, 2002. 100(2): p. 136-9.

88. Kinoshita, A., et al., Elevation of 8-hydroxydeoxyguanosine and cell proliferation via generation of oxidative stress by organic arsenicals contributes to their carcinogenicity in the rat liver and bladder. Toxicol Appl Pharmacol, 2007. 221(3): p. 295-305.

89. Shen, J., et al., Liver tumorigenicity of trimethylarsine oxide in male Fischer 344 rats--association with oxidative DNA damage and enhanced cell proliferation. Carcinogenesis, 2003. 24(11): p. 1827-35.

90. Andrew, A.S., et al., Arsenic exposure is associated with decreased DNA repair in vitro and in individuals exposed to drinking water arsenic. Environ Health Perspect, 2006. 114(8): p. 1193-8.

91. Hartwig, A., et al., Modulation of DNA repair processes by arsenic and selenium compounds. Toxicology, 2003. 193(1-2): p. 161-9.

92. Qu, W., et al., Acquisition of apoptotic resistance in arsenic-induced malignant transformation: role of the JNK signal transduction pathway. Carcinogenesis, 2002. 23(1): p. 151-9.

93. Zhao, C.Q., et al., Association of arsenic-induced malignant transformation with DNA hypomethylation and aberrant gene expression. Proc Natl Acad Sci U S A, 1997. 94(20): p. 10907-12.

94. Chen, $\mathrm{H}$., et al., Chronic inorganic arsenic exposure induces hepatic global and individual gene hypomethylation: implications for arsenic hepatocarcinogenesis. Carcinogenesis, 2004. 25(9): p. 1779-86.

95. Okoji, R.S., et al., Sodium arsenite administration via drinking water increases genome-wide and Ha-ras DNA hypomethylation in methyl-deficient C57BL/6J mice. Carcinogenesis, 2002. 23(5): p. 777-85. 
96. Xie, Y., et al., Aberrant DNA methylation and gene expression in livers of newborn mice transplacentally exposed to a hepatocarcinogenic dose of inorganic arsenic. Toxicology, 2007. 236(1-2): p. 7-15.

97. IARC, Arsenic and Arsenic Compounds. 2012, IARC Press, Lyons.

98. Tsuji, J.S., et al., Dose-response for assessing the cancer risk of inorganic arsenic in drinking water: the scientific basis for use of a threshold approach. Crit Rev Toxicol, 2019. 49(1): p. 36-84.

99. Vahter, M., Methylation of inorganic arsenic in different mammalian species and population groups. Sci Prog, 1999. 82 ( Pt 1): p. 69-88.

100. Styblo, M., et al., Differential metabolism of inorganic arsenic in mice from genetically diverse Collaborative Cross strains. Arch Toxicol, 2019. 93(10): p. 2811-2822.

101. Boffetta, P. and C. Borron, Low-Level Exposure to Arsenic in Drinking Water and Risk of Lung and Bladder Cancer: A Systematic Review and Dose-Response Meta-Analysis. Dose Response, 2019. 17(3): p. 1559325819863634.

102. Ferreccio, C., et al., Lung cancer and arsenic concentrations in drinking water in Chile. Epidemiology, 2000. 11(6): p. 673-9.

103. Mostafa, M.G., J.C. McDonald, and N.M. Cherry, Lung cancer and exposure to arsenic in rural Bangladesh. Occup Environ Med, 2008. 65(11): p. 765-8.

104. Lynch, H.N., et al., Quantitative assessment of lung and bladder cancer risk and oral exposure to inorganic arsenic: Meta-regression analyses of epidemiological data. Environ Int, 2017. 106: p. 178-206.

105. D'Ippoliti, D., et al., Arsenic in Drinking Water and Mortality for Cancer and Chronic Diseases in Central Italy, 1990-2010. PLoS One, 2015. 10(9): p. e0138182.

106. Guo, H.R., et al., Arsenic in drinking water and skin cancers: cell-type specificity (Taiwan, ROC). Cancer Causes Control, 2001. 12(10): p. 909-16.

107. Zuzolo, D., et al., Arsenic: Geochemical distribution and age-related health risk in Italy. Environ Res, 2020. 182: p. 109076.

108. Moon, K.A., et al., A dose-response meta-analysis of chronic arsenic exposure and incident cardiovascular disease. Int J Epidemiol, 2018. 47(3): p. 1013.

109. Wang, C.H., et al., Biological gradient between long-term arsenic exposure and carotid atherosclerosis. Circulation, 2002. 105(15): p. 1804-9.

110. Mumford, J.L., et al., Chronic arsenic exposure and cardiac repolarization abnormalities with QT interval prolongation in a population-based study. Environ Health Perspect, 2007. 115(5): p. 690-4.

111. Hossain, E., et al., Elevated levels of plasma Big endothelin-1 and its relation to hypertension and skin lesions in individuals exposed to arsenic. Toxicol Appl Pharmacol, 2012. 259(2): p. 187-94.

112. Lee, P.C., I.C. Ho, and T.C. Lee, Oxidative stress mediates sodium arseniteinduced expression of heme oxygenase-1, monocyte chemoattractant protein-1, and interleukin-6 in vascular smooth muscle cells. Toxicol Sci, 2005. 85(1): p. 541-50.

113. Hubaux, R., et al., Molecular features in arsenic-induced lung tumors. Mol Cancer, 2013. 12: p. 20.

114. Putila, J.J. and N.L. Guo, Association of arsenic exposure with lung cancer incidence rates in the United States. PLoS One, 2011. 6(10): p. e25886.

115. Mendez, W.M., Jr., et al., Relationships between arsenic concentrations in drinking water and lung and bladder cancer incidence in U.S. counties. J Expo Sci Environ Epidemiol, 2017. 27(3): p. 235-243. 
116. Tseng, W.P., et al., Prevalence of skin cancer in an endemic area of chronic arsenicism in Taiwan. J Natl Cancer Inst, 1968. 40(3): p. 453-63.

117. Cebrian, M.E., et al., Chronic arsenic poisoning in the north of Mexico. Hum Toxicol, 1983. 2(1): p. 121-33.

118. Chakraborty, A.K. and K.C. Saha, Arsenical dermatosis from tubewell water in West Bengal. Indian J Med Res, 1987. 85: p. 326-34.

119. Zaldivar, R., Arsenic contamination of drinking water and foodstuffs causing endemic chronic poisoning. Beitr Pathol, 1974. 151(4): p. 384-400.

120. Bergoglio, R.M., [Cancer Mortality in Zones of Arsenical Waters of the Province of Cordoba, Argentine Republic. Contribution to the Regional Pathology of Cancer]. Prensa Med Argent, 1964. 51: p. 994-8.

121. Chen, C.J., T.L. Kuo, and M.M. Wu, Arsenic and cancers. Lancet, 1988. 1(8582): p. 414-5.

122. Tsuda, T., et al., An epidemiological study on cancer in certified arsenic poisoning patients in Toroku. Ind Health, 1990. 28(2): p. 53-62.

123. Wu, M.M., et al., Dose-response relation between arsenic concentration in well water and mortality from cancers and vascular diseases. Am J Epidemiol, 1989. 130(6): p. 1123-32.

124. Celik, I., et al., Arsenic in drinking water and lung cancer: a systematic review. Environ Res, 2008. 108(1): p. 48-55.

125. Gibb, H., et al., Utility of recent studies to assess the National Research Council 2001 estimates of cancer risk from ingested arsenic. Environ Health Perspect, 2011. 119(3): p. 284-90.

126. $\quad$ in Arsenic in Drinking Water. 1999: Washington (DC).

127. Chen, C.J., et al., A retrospective study on malignant neoplasms of bladder, lung and liver in blackfoot disease endemic area in Taiwan. Br J Cancer, 1986. 53(3): p. 399-405.

128. Tsuda, T., et al., Ingested arsenic and internal cancer: a historical cohort study followed for 33 years. Am J Epidemiol, 1995. 141(3): p. 198-209.

129. Christian, W.J., et al., Exploring geographic variation in lung cancer incidence in Kentucky using a spatial scan statistic: elevated risk in the Appalachian coalmining region. Public Health Rep, 2011. 126(6): p. 789-96.

130. Uddin, R. and N.H. Huda, Arsenic poisoning in bangladesh. Oman Med J, 2011. 26(3): p. 207.

131. Chen, C.J. and C.J. Wang, Ecological correlation between arsenic level in well water and age-adjusted mortality from malignant neoplasms. Cancer Res, 1990. 50(17): p. 5470-4.

132. Smith, A.H., et al., Marked increase in bladder and lung cancer mortality in a region of Northern Chile due to arsenic in drinking water. Am J Epidemiol, 1998. 147(7): p. 660-9.

133. Sohel, N., et al., Arsenic in drinking water and adult mortality: a population-based cohort study in rural Bangladesh. Epidemiology, 2009. 20(6): p. 824-30.

134. Waalkes, M.P., et al., Enhanced urinary bladder and liver carcinogenesis in male CD1 mice exposed to transplacental inorganic arsenic and postnatal diethylstilbestrol or tamoxifen. Toxicol Appl Pharmacol, 2006. 215(3): p. 295-305.

135. Huff, J., M.F. Jacobson, and D.L. Davis, The limits of two-year bioassay exposure regimens for identifying chemical carcinogens. Environ Health Perspect, 2008. 116(11): p. 1439-42.

136. Waalkes, M.P., et al., Transplacental carcinogenicity of inorganic arsenic in the drinking water: induction of hepatic, ovarian, pulmonary, and adrenal tumors in mice. Toxicol Appl Pharmacol, 2003. 186(1): p. 7-17. 
137. Young, J.L., L. Cai, and J.C. States, Impact of prenatal arsenic exposure on chronic adult diseases. Syst Biol Reprod Med, 2018: p. 1-15.

138. Tokar, E.J., B.A. Diwan, and M.P. Waalkes, Arsenic exposure in utero and nonepidermal proliferative response in adulthood in Tg.AC mice. Int $\mathrm{J}$ Toxicol, 2010. 29(3): p. 291-6.

139. Ren, Q., et al., Malignant transformation of immortalized HaCaT keratinocytes through deregulated nuclear factor kappaB signaling. Cancer Res, 2006. 66(10): p. 5209-15.

140. Ramirez, R.D., et al., Immortalization of human bronchial epithelial cells in the absence of viral oncoproteins. Cancer Res, 2004. 64(24): p. 9027-34.

141. Germolec, D.R., et al., Arsenic induces overexpression of growth factors in human keratinocytes. Toxicol Appl Pharmacol, 1996. 141(1): p. 308-18.

142. Sandoval, M., et al., p53 response to arsenic exposure in epithelial cells: protein kinase B/Akt involvement. Toxicol Sci, 2007. 99(1): p. 126-40.

143. Zhang, M., et al., AIM2 inflammasome mediates Arsenic-induced secretion of IL1 beta and IL-18. Oncoimmunology, 2016. 5(6): p. e1160182.

144. Shah, P., et al., Arsenic Induces p62 Expression to Form a Positive Feedback Loop with Nrf2 in Human Epidermal Keratinocytes: Implications for Preventing Arsenic-Induced Skin Cancer. Molecules, 2017. 22(2).

145. Wu, X., et al., NRF2 Is a Potential Modulator of Hyperresistance to Arsenic Toxicity in Stem-Like Keratinocytes. Oxid Med Cell Longev, 2017. 2017: p. 7417694.

146. Zhang, A.L., et al., Role of H3K18ac-regulated nucleotide excision repair-related genes in arsenic-induced DNA damage and repair of HaCaT cells. Hum Exp Toxicol, 2020: p. 960327120903482.

147. Mao, J., et al., Possible differences in the mechanism of malignant transformation of $\mathrm{HaCaT}$ cells by arsenite and its dimethyl metabolites, particularly dimethylthioarsenics. J Trace Elem Med Biol, 2020. 61: p. 126544.

148. Wang, S., et al., Overexpression of NRF1-742 or NRF1-772 Reduces ArsenicInduced Cytotoxicity and Apoptosis in Human HaCaT Keratinocytes. Int J Mol Sci, 2020. 21(6).

149. Zhang, A.L., et al., Role of H3K18ac-regulated nucleotide excision repair-related genes in arsenic-induced DNA damage and repair of HaCaT cells. Hum Exp Toxicol, 2020. 39(9): p. 1168-1177.

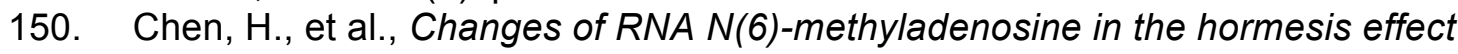
induced by arsenite on human keratinocyte cells. Toxicol In Vitro, 2019. 56: p. 84-92.

151. Ouyang, W., et al., Pl-3K/Akt pathway-dependent cyclin D1 expression is responsible for arsenite-induced human keratinocyte transformation. Environ Health Perspect, 2008. 116(1): p. 1-6.

152. Huang, S., et al., CD44v6 expression in human skin keratinocytes as a possible mechanism for carcinogenesis associated with chronic arsenic exposure. Eur J Histochem, 2013. 57(1): p. e1.

153. Gonzalez, H., et al., Arsenic-exposed Keratinocytes Exhibit Differential microRNAs Expression Profile; Potential Implication of miR-21, miR-200a and miR-141 in Melanoma Pathway. Clin Cancer Drugs, 2015. 2(2): p. 138-147.

154. Jiang, R., et al., The acquisition of cancer stem cell-like properties and neoplastic transformation of human keratinocytes induced by arsenite involves epigenetic silencing of let-7c via Ras/NF-kappaB. Toxicol Lett, 2014. 227(2): p. 91-8.

155. Al-Eryani, L., et al., Differentially Expressed mRNA Targets of Differentially Expressed miRNAs Predict Changes in the TP53 Axis and Carcinogenesis- 
Related Pathways in Human Keratinocytes Chronically Exposed to Arsenic. Toxicol Sci, 2018. 162(2): p. 645-654.

156. Al-Eryani, L., et al., Cell cycle pathway dysregulation in human keratinocytes during chronic exposure to low arsenite. Toxicol Appl Pharmacol, 2017. 331: p. 130-134.

157. Banerjee, N., et al., Increased microRNA 21 expression contributes to arsenic induced skin lesions, skin cancers and respiratory distress in chronically exposed individuals. Toxicology, 2017. 378: p. 10-16.

158. Chen, Y., et al., Akt Regulated Phosphorylation of GSK-3beta/Cyclin D1, p21 and p27 Contributes to Cell Proliferation Through Cell Cycle Progression From G1 to S/G2M Phase in Low-Dose Arsenite Exposed HaCat Cells. Front Pharmacol, 2019. 10: p. 1176.

159. Liu, Z.M., et al., TG-interacting factor mediates arsenic-induced malignant transformation of keratinocytes via c-Src/EGFR/AKT/FOXO3A and redox signalings. Arch Toxicol, 2015. 89(12): p. 2229-41.

160. Wu, J., et al., Overexpression of hsa-miR-186 induces chromosomal instability in arsenic-exposed human keratinocytes. Toxicol Appl Pharmacol, 2019. 378: p. 114614.

161. Banerjee, M., et al., Arsenite Exposure Displaces Zinc from ZRANB2 Leading to Altered Splicing. Chem Res Toxicol, 2020.

162. Wu, J., et al., Long-term arsenite exposure decreases autophagy by increased release of Nrf2 in transformed human keratinocytes. Sci Total Environ, 2020. 734: p. 139425.

163. Zhao, T., et al., N(6)-methyladenosine mediates arsenite-induced human keratinocyte transformation by suppressing p53 activation. Environ Pollut, 2020. 259: p. 113908.

164. Xue, J., et al., CircLRP6 Regulation of ZEB1 via miR-455 Is Involved in the Epithelial-Mesenchymal Transition During Arsenite-Induced Malignant Transformation of Human Keratinocytes. Toxicol Sci, 2018. 162(2): p. 450-461.

165. $\mathrm{Pi}$, J., et al., Arsenic-induced malignant transformation of human keratinocytes: involvement of Nrf2. Free Radic Biol Med, 2008. 45(5): p. 651-8.

166. Sun, Y., et al., Aberrant cytokeratin expression during arsenic-induced acquired malignant phenotype in human HaCaT keratinocytes consistent with epidermal carcinogenesis. Toxicology, 2009. 262(2): p. 162-70.

167. Zhou, Y., et al., Integration of microRNAome, proteomics and metabolomics to analyze arsenic-induced malignant cell transformation. Oncotarget, 2017. 8(53): p. 90879-90896.

168. Alexander, E.T., et al., Polyamine-stimulation of arsenic-transformed keratinocytes. Carcinogenesis, 2019. 40(8): p. 1042-1051.

169. Wu, X., et al., Enhanced p62-NRF2 Feedback Loop due to Impaired Autophagic Flux Contributes to Arsenic-Induced Malignant Transformation of Human Keratinocytes. Oxid Med Cell Longev, 2019. 2019: p. 1038932.

170. Barajas-Olmos, F.M., et al., Analysis of the dynamic aberrant landscape of DNA methylation and gene expression during arsenic-induced cell transformation. Gene, 2019. 711: p. 143941.

171. Olsen, C.E., et al., Arsenic upregulates MMP-9 and inhibits wound repair in human airway epithelial cells. Am J Physiol Lung Cell Mol Physiol, 2008. 295(2): p. L293-302.

172. Andrew, A.S., et al., Arsenic activates EGFR pathway signaling in the lung. Toxicol Sci, 2009. 109(2): p. 350-7. 
173. Luo, F., et al., Arsenite evokes IL-6 secretion, autocrine regulation of STAT3 signaling, and miR-21 expression, processes involved in the EMT and malignant transformation of human bronchial epithelial cells. Toxicol Appl Pharmacol, 2013. 273(1): p. 27-34.

174. Xu, Y., et al., EMT and stem cell-like properties associated with HIF-2alpha are involved in arsenite-induced transformation of human bronchial epithelial cells. PLoS One, 2012. 7(5): p. e37765.

175. He, J., et al., Chronic arsenic exposure and angiogenesis in human bronchial epithelial cells via the ROS/miR-199a-5p/HIF-1alpha/COX-2 pathway. Environ Health Perspect, 2014. 122(3): p. 255-61.

176. Luo, F., et al., MicroRNA-21, up-regulated by arsenite, directs the epithelialmesenchymal transition and enhances the invasive potential of transformed human bronchial epithelial cells by targeting PDCD4. Toxicol Lett, 2015. 232(1): p. 301-9.

177. Qi, Y., et al., Autophagy inhibition by sustained overproduction of IL6 contributes to arsenic carcinogenesis. Cancer Res, 2014. 74(14): p. 3740-52.

178. Chen, C., et al., Protection of Nrf2 against arsenite-induced oxidative damage is regulated by the cyclic guanosine monophosphate-protein kinase $G$ signaling pathway. Environ Toxicol, 2017. 32(8): p. 2004-2020.

179. Chen, C., et al., Arsenite-induced endoplasmic reticulum-dependent apoptosis through disturbance of calcium homeostasis in HBE cell line. Environ Toxicol, 2017. 32(1): p. 197-216.

180. Sherwood, C.L., et al., Arsenic alters ATP-dependent $\mathrm{Ca}(2)+$ signaling in human airway epithelial cell wound response. Toxicol Sci, 2011. 121(1): p. 191-206.

181. Liu, Y., et al., Arsenic represses airway epithelial mucin expression by affecting retinoic acid signaling pathway. Toxicol Appl Pharmacol, 2020. 394: p. 114959.

182. Li, M., J.F. Cai, and J.F. Chiu, Arsenic induces oxidative stress and activates stress gene expressions in cultured lung epithelial cells. J Cell Biochem, 2002. 87(1): p. 29-38.

183. Bomberger, J.M., et al., Arsenic promotes ubiquitinylation and lysosomal degradation of cystic fibrosis transmembrane conductance regulator (CFTR) chloride channels in human airway epithelial cells. J Biol Chem, 2012. 287(21): p. 17130-9.

184. Ling, M., et al., Regulation of miRNA-21 by reactive oxygen species-activated ERK/NF-kappaB in arsenite-induced cell transformation. Free Radic Biol Med, 2012. 52(9): p. 1508-18.

185. Sherwood, C.L., R.C. Lantz, and S. Boitano, Chronic arsenic exposure in nanomolar concentrations compromises wound response and intercellular signaling in airway epithelial cells. Toxicol Sci, 2013. 132(1): p. 222-34.

186. Shen, L., et al., Feedback regulations of miR-21 and MAPKs via Pdcd4 and Spry1 are involved in arsenite-induced cell malignant transformation. PLoS One, 2013. 8(3): p. e57652.

187. Tu, W., et al., Arsenite downregulates H3K4 trimethylation and H3K9 dimethylation during transformation of human bronchial epithelial cells. J Appl Toxicol, 2018. 38(4): p. 480-488.

188. Chen, C., et al., MicroRNA-155 regulates arsenite-induced malignant transformation by targeting Nrf2-mediated oxidative damage in human bronchial epithelial cells. Toxicol Lett, 2017. 278: p. 38-47.

189. Ganapathy, S., et al., Chronic low dose arsenic exposure preferentially perturbs mitotic phase of the cell cycle. Genes Cancer, 2019. 10(1-2): p. 39-51. 
190. Cui, J., et al., M2 polarization of macrophages facilitates arsenic-induced cell transformation of lung epithelial cells. Oncotarget, 2017. 8(13): p. 21398-21409.

191. Chen, Q.Y. and M. Costa, Oncogenic and tumor suppressive roles of special ATrich sequence-binding protein. J Carcinog, 2018. 17: p. 2.

192. Wu, L., et al., Autophagy mediates bronchial cell malignant transformation induced by chronic arsenic exposure via MEKJERK1/2 pathway. Toxicol Lett, 2020. 332: p. 155-163.

193. Schmidlin, C.J., et al., Chronic arsenic exposure enhances metastatic potential via NRF2-mediated upregulation of SOX9. Toxicol Appl Pharmacol, 2020. 402: $p$. 115138.

194. Gu, S., et al., N(6)-methyladenosine mediates the cellular proliferation and apoptosis via microRNAs in arsenite-transformed cells. Toxicol Lett, 2018. 292: p. 1-11.

195. Goodale, B.C., E.J. Rayack, and B.A. Stanton, Arsenic alters transcriptional responses to Pseudomonas aeruginosa infection and decreases antimicrobial defense of human airway epithelial cells. Toxicol Appl Pharmacol, 2017. 331: p. 154-163.

196. Xu, W., et al., HIF-2alpha, acting via miR-191, is involved in angiogenesis and metastasis of arsenite-transformed HBE cells. Toxicol Res (Camb), 2016. 5(1): p. 66-78.

197. Yang, X., et al., Continuous activation of Nrf2 and its target antioxidant enzymes leads to arsenite-induced malignant transformation of human bronchial epithelial cells. Toxicol Appl Pharmacol, 2015. 289(2): p. 231-9.

198. Xu, Y., et al., Exosomal miR-21 derived from arsenite-transformed human bronchial epithelial cells promotes cell proliferation associated with arsenite carcinogenesis. Arch Toxicol, 2015. 89(7): p. 1071-82.

199. Zhao, Y., et al., Angiogenesis, mediated by miR-21, is involved arsenite-induced carcinogenesis. Toxicol Lett, 2013. 223(1): p. 35-41.

200. Xu, Y., et al., Involvement of HIF-2alpha-mediated inflammation in arseniteinduced transformation of human bronchial epithelial cells. Toxicol Appl Pharmacol, 2013. 272(2): p. 542-50.

201. Sherwood, C.L., et al., Arsenic compromises conducting airway epithelial barrier properties in primary mouse and immortalized human cell cultures. PLoS One, 2013. 8(12): p. e82970.

202. Wen, G., et al., Neoplastic transformation of human small airway epithelial cells induced by arsenic. Mol Med, 2008. 14(1-2): p. 2-10.

203. Carpenter, R.L., et al., Arsenite induces cell transformation by reactive oxygen species, AKT, ERK1/2, and p70S6K1. Biochem Biophys Res Commun, 2011. 414(3): p. 533-8.

204. Zhong, M., et al., Malignant Transformation of Human Bronchial Epithelial Cells Induced by Arsenic through STAT3/miR-301a/SMAD4 Loop. Sci Rep, 2018. 8(1): p. 13291.

205. Wang, W., et al., Changes in energy metabolism and macrophage polarization: Potential mechanisms of arsenic-induced lung injury. Ecotoxicol Environ Saf, 2020. 204: p. 110948.

206. Wang, L., et al., HB-EGF Activates the EGFR/HIF-1alpha Pathway to Induce Proliferation of Arsenic-Transformed Cells and Tumor Growth. Front Oncol, 2020. 10: p. 1019.

207. Vermeulen, K., D.R. Van Bockstaele, and Z.N. Berneman, The cell cycle: a review of regulation, deregulation and therapeutic targets in cancer. Cell Prolif, 2003. 36(3): p. 131-49. 
208. Bower, J.J., et al., Patterns of cell cycle checkpoint deregulation associated with intrinsic molecular subtypes of human breast cancer cells. NPJ Breast Cancer, 2017. 3: p. 9.

209. Wang, H., et al., microRNA-21 promotes breast cancer proliferation and metastasis by targeting LZTFL1. BMC Cancer, 2019. 19(1): p. 738.

210. Wu, Y., et al., MicroRNA-21 (Mir-21) Promotes Cell Growth and Invasion by Repressing Tumor Suppressor PTEN in Colorectal Cancer. Cell Physiol Biochem, 2017. 43(3): p. 945-958.

211. Shi, C., et al., Novel evidence for an oncogenic role of microRNA-21 in colitisassociated colorectal cancer. Gut, 2016. 65(9): p. 1470-81.

212. Huang, H., Matrix Metalloproteinase-9 (MMP-9) as a Cancer Biomarker and MMP-9 Biosensors: Recent Advances. Sensors (Basel), 2018. 18(10).

213. Kurzius-Spencer, M., et al., Relation of dietary inorganic arsenic to serum matrix metalloproteinase-9 (MMP-9) at different threshold concentrations of tap water arsenic. J Expo Sci Environ Epidemiol, 2016. 26(5): p. 445-51.

214. Burgess, J.L., et al., Environmental arsenic exposure and serum matrix metalloproteinase-9. J Expo Sci Environ Epidemiol, 2013. 23(2): p. 163-9.

215. Islam, M.S., et al., Elevated concentrations of serum matrix metalloproteinase-2 and -9 and their associations with circulating markers of cardiovascular diseases in chronic arsenic-exposed individuals. Environ Health, 2015. 14: p. 92.

216. Josyula, A.B., et al., Environmental arsenic exposure and sputum metalloproteinase concentrations. Environ Res, 2006. 102(3): p. 283-90.

217. Dong, J.T. and X.M. Luo, Arsenic-induced DNA-strand breaks associated with DNA-protein crosslinks in human fetal lung fibroblasts. Mutat Res, 1993. 302(2): p. 97-102.

218. Yamanaka, K., et al., Metabolic methylation is a possible genotoxicity-enhancing process of inorganic arsenics. Mutat Res, 1997. 394(1-3): p. 95-101.

219. Mouron, S.A., et al., Induction of DNA strand breaks, DNA-protein crosslinks and sister chromatid exchanges by arsenite in a human lung cell line. Toxicol In Vitro, 2006. 20(3): p. 279-85.

220. Yamanaka, K., et al., Involvement of preferential formation of apurinic/apyrimidinic sites in dimethylarsenic-induced DNA strand breaks and DNA-protein crosslinks in cultured alveolar epithelial cells. Biochem Biophys Res Commun, 1995. 207(1): p. 244-9.

221. Ruiz-Ramos, R., et al., Sodium arsenite induces ROS generation, DNA oxidative damage, HO-1 and c-Myc proteins, NF-kappaB activation and cell proliferation in human breast cancer MCF-7 cells. Mutat Res, 2009. 674(1-2): p. 109-15.

222. An, Y., et al., Specific induction of oxidative stress in terminal bronchiolar Clara cells during dimethylarsenic-induced lung tumor promoting process in mice. Cancer Lett, 2005. 230(1): p. 57-64.

223. Martinez, V.D., et al., Arsenic exposure and the induction of human cancers. J Toxicol, 2011. 2011: p. 431287.

224. Mass, M.J. and L. Wang, Arsenic alters cytosine methylation patterns of the promoter of the tumor suppressor gene $p 53$ in human lung cells: a model for a mechanism of carcinogenesis. Mutat Res, 1997. 386(3): p. 263-77.

225. Cui, Y., et al., MicroRNA-181b and microRNA-9 mediate arsenic-induced angiogenesis via NRP1. J Cell Physiol, 2012. 227(2): p. 772-83.

226. Zhou, X., et al., Arsenite alters global histone H3 methylation. Carcinogenesis, 2008. 29(9): p. 1831-6.

227. Jensen, T.J., et al., Epigenetic remodeling during arsenical-induced malignant transformation. Carcinogenesis, 2008. 29(8): p. 1500-8. 
228. Marsit, C.J., K. Eddy, and K.T. Kelsey, MicroRNA responses to cellular stress. Cancer Res, 2006. 66(22): p. 10843-8.

229. Wang, Z., et al., Reversal and prevention of arsenic-induced human bronchial epithelial cell malignant transformation by microRNA-200b. Toxicol Sci, 2011. 121(1): p. 110-22.

230. Intarasunanont, $\mathrm{P}$., et al., Effects of arsenic exposure on DNA methylation in cord blood samples from newborn babies and in a human lymphoblast cell line. Environ Health, 2012. 11: p. 31.

231. Jensen, T.J., et al., Epigenetic mediated transcriptional activation of WNT5A participates in arsenical-associated malignant transformation. Toxicol Appl Pharmacol, 2009. 235(1): p. 39-46.

232. Cui, X., et al., Chronic oral exposure to inorganic arsenate interferes with methylation status of $p 16 I N K 4 a$ and RASSF1A and induces lung cancer in $A / J$ mice. Toxicol Sci, 2006. 91(2): p. 372-81.

233. Bailey, K.A. and R.C. Fry, Arsenic-Associated Changes to the Epigenome: What Are the Functional Consequences? Curr Environ Health Rep, 2014. 1: p. 22-34.

234. Reichard, J.F. and A. Puga, Effects of arsenic exposure on DNA methylation and epigenetic gene regulation. Epigenomics, 2010. 2(1): p. 87-104.

235. States, J.C., Disruption of Mitotic Progression by Arsenic. Biol Trace Elem Res, 2015. 166(1): p. 34-40.

236. Samet, J.M., et al., Activation of MAPKs in human bronchial epithelial cells exposed to metals. Am J Physiol, 1998. 275(3 Pt 1): p. L551-8.

237. Simeonova, P.P., et al., c-Src-dependent activation of the epidermal growth factor receptor and mitogen-activated protein kinase pathway by arsenic. Role in carcinogenesis. J Biol Chem, 2002. 277(4): p. 2945-50.

238. Liu, J., et al., JNK-dependent Stat 3 phosphorylation contributes to Akt activation in response to arsenic exposure. Toxicol Sci, 2012. 129(2): p. 363-71.

239. Herbert, K.J. and E.T. Snow, Modulation of arsenic-induced epidermal growth factor receptor pathway signalling by resveratrol. Chem Biol Interact, 2012. 198(1-3): p. 38-48.

240. Verma, A., et al., Activation of Rac1 and the $p 38$ mitogen-activated protein kinase pathway in response to arsenic trioxide. J Biol Chem, 2002. 277(47): p. 44988-95.

241. Stueckle, T.A., et al., Chronic occupational exposure to arsenic induces carcinogenic gene signaling networks and neoplastic transformation in human lung epithelial cells. Toxicol Appl Pharmacol, 2012. 261(2): p. 204-16.

242. Gao, N., et al., Arsenite induces HIF-1alpha and VEGF through PI3K, Akt and reactive oxygen species in DU145 human prostate carcinoma cells. Mol Cell Biochem, 2004. 255(1-2): p. 33-45.

243. Dong, Z., The molecular mechanisms of arsenic-induced cell transformation and apoptosis. Environ Health Perspect, 2002. 110 Suppl 5: p. 757-9.

244. Chen, B., et al., JNK and STAT3 signaling pathways converge on Akt-mediated phosphorylation of EZH2 in bronchial epithelial cells induced by arsenic. Cell Cycle, 2013. 12(1): p. 112-21.

245. Wang, Z., et al., Akt activation is responsible for enhanced migratory and invasive behavior of arsenic-transformed human bronchial epithelial cells. Environ Health Perspect, 2012. 120(1): p. 92-7.

246. Chen, W., et al., Tumor promoter arsenite activates extracellular signal-regulated kinase through a signaling pathway mediated by epidermal growth factor receptor and Shc. Mol Cell Biol, 1998. 18(9): p. 5178-88. 
247. Cooper, K.L., et al., Roles of mitogen activated protein kinases and EGF receptor in arsenite-stimulated matrix metalloproteinase-9 production. Toxicol Appl Pharmacol, 2004. 200(3): p. 177-85.

248. Ivanov, V.N. and T.K. Hei, Combined treatment with EGFR inhibitors and arsenite upregulated apoptosis in human EGFR-positive melanomas: a role of suppression of the PI3K-AKT pathway. Oncogene, 2005. 24(4): p. 616-26.

249. Liu, L.Z., et al., Reactive oxygen species regulate epidermal growth factorinduced vascular endothelial growth factor and hypoxia-inducible factor-1alpha expression through activation of AKT and P70S6K1 in human ovarian cancer cells. Free Radic Biol Med, 2006. 41(10): p. 1521-33.

250. Tanaka-Kagawa, T., et al., Arsenite and arsenate activate extracellular signalregulated kinases $1 / 2$ by an epidermal growth factor receptor-mediated pathway in normal human keratinocytes. Br J Dermatol, 2003. 149(6): p. 1116-27.

251. Wen, G., et al., Phosphoproteomic profiling of arsenite-treated human small airway epithelial cells. Oncol Rep, 2010. 23(2): p. 405-12.

252. Wu, W., et al., Role of Ras in metal-induced EGF receptor signaling and NFkappaB activation in human airway epithelial cells. Am J Physiol Lung Cell Mol Physiol, 2002. 282(5): p. L1040-8.

253. Wu, W., et al., Activation of the EGF receptor signaling pathway in human airway epithelial cells exposed to metals. Am J Physiol, 1999. 277(5 Pt 1): p. L924-31.

254. Muller, V., et al., Prognostic and predictive impact of soluble epidermal growth factor receptor (sEGFR) protein in the serum of patients treated with chemotherapy for metastatic breast cancer. Anticancer Res, 2006. 26(2B): p. 1479-87.

255. Ribeiro, F.A., et al., Effective targeting of the epidermal growth factor receptor (EGFR) for treating oral cancer: a promising approach. Anticancer Res, 2014. 34(4): p. 1547-52.

256. Korpanty, G.J., et al., Biomarkers That Currently Affect Clinical Practice in Lung Cancer: EGFR, ALK, MET, ROS-1, and KRAS. Front Oncol, 2014. 4: p. 204.

257. Vincent, M.D., et al., Biomarkers that currently affect clinical practice: EGFR, ALK, MET, KRAS. Curr Oncol, 2012. 19(Suppl 1): p. S33-44.

258. Nicholson, S., et al., Epidermal growth factor receptor (EGFr); results of a 6 year follow-up study in operable breast cancer with emphasis on the node negative subgroup. Br J Cancer, 1991. 63(1): p. 146-50.

259. Lipponen, P. and M. Eskelinen, Expression of epidermal growth factor receptor in bladder cancer as related to established prognostic factors, oncoprotein (c-erbB2, p53) expression and long-term prognosis. Br J Cancer, 1994. 69(6): p. 1120-5.

260. De Jong, K.P., et al., Clinical relevance of transforming growth factor alpha, epidermal growth factor receptor, p53, and Ki67 in colorectal liver metastases and corresponding primary tumors. Hepatology, 1998. 28(4): p. 971-9.

261. Toschi, L. and F. Cappuzzo, Understanding the new genetics of responsiveness to epidermal growth factor receptor tyrosine kinase inhibitors. Oncologist, 2007. 12(2): p. 211-20.

262. Mendelsohn, J., The epidermal growth factor receptor as a target for cancer therapy. Endocr Relat Cancer, 2001. 8(1): p. 3-9.

263. Herbst, R.S., Review of epidermal growth factor receptor biology. Int J Radiat Oncol Biol Phys, 2004. 59(2 Suppl): p. 21-6.

264. Kaufman, M., et al., EGFR expression in gallbladder carcinoma in North America. Int J Med Sci, 2008. 5(5): p. 285-91. 
265. Lee, H.J., et al., Prognostic and predictive values of EGFR overexpression and EGFR copy number alteration in HER2-positive breast cancer. Br J Cancer, 2015. 112(1): p. 103-11.

266. Schiff, B.A., et al., Epidermal growth factor receptor (EGFR) is overexpressed in anaplastic thyroid cancer, and the EGFR inhibitor gefitinib inhibits the growth of anaplastic thyroid cancer. Clin Cancer Res, 2004. 10(24): p. 8594-602.

267. Maiti, G.P., et al., Overexpression of EGFR in head and neck squamous cell carcinoma is associated with inactivation of SH3GL2 and CDC25A genes. PLoS One, 2013. 8(5): p. e63440.

268. Zhou, Q., et al., In vivo photoacoustic tomography of EGFR overexpressed in hepatocellular carcinoma mouse xenograft. Photoacoustics, 2016. 4(2): p. 43-54.

269. Ito, Y., et al., Expression and clinical significance of erb-B receptor family in hepatocellular carcinoma. Br J Cancer, 2001. 84(10): p. 1377-83.

270. Buckley, A.F., et al., Epidermal growth factor receptor expression and gene copy number in conventional hepatocellular carcinoma. Am J Clin Pathol, 2008. 129(2): p. 245-51.

271. Bhargava, R., et al., EGFR gene amplification in breast cancer: correlation with epidermal growth factor receptor $m R N A$ and protein expression and HER-2 status and absence of EGFR-activating mutations. Mod Pathol, 2005. 18(8): p. 1027-33.

272. Jimeno, A., et al., Coordinated epidermal growth factor receptor pathway gene overexpression predicts epidermal growth factor receptor inhibitor sensitivity in pancreatic cancer. Cancer Res, 2008. 68(8): p. 2841-9.

273. Reuter, C.W., M.A. Morgan, and A. Eckardt, Targeting EGF-receptor-signalling in squamous cell carcinomas of the head and neck. Br J Cancer, 2007. 96(3): p. 408-16.

274. da Cunha Santos, G., F.A. Shepherd, and M.S. Tsao, EGFR mutations and lung cancer. Annu Rev Pathol, 2011. 6: p. 49-69.

275. Veale, D., et al., The relationship of quantitative epidermal growth factor receptor expression in non-small cell lung cancer to long term survival. Br J Cancer, 1993. 68(1): p. 162-5.

276. Hirsch, F.R., et al., Epidermal growth factor receptor in non-small-cell lung carcinomas: correlation between gene copy number and protein expression and impact on prognosis. J Clin Oncol, 2003. 21(20): p. 3798-807.

277. Tong, D., et al., Arsenic Inhibits DNA Mismatch Repair by Promoting EGFR Expression and PCNA Phosphorylation. J Biol Chem, 2015. 290(23): p. 1453641.

278. Jones, J.T., R.W. Akita, and M.X. Sliwkowski, Binding specificities and affinities of egf domains for ErbB receptors. FEBS Lett, 1999. 447(2-3): p. 227-31.

279. Sanders, J.M., et al., Molecular determinants of epidermal growth factor binding: a molecular dynamics study. PLoS One, 2013. 8(1): p. e54136.

280. Ronan, T., et al., Different Epidermal Growth Factor Receptor (EGFR) Agonists Produce Unique Signatures for the Recruitment of Downstream Signaling Proteins. J Biol Chem, 2016. 291(11): p. 5528-40.

281. Chia, C.M., R.M. Winston, and A.H. Handyside, EGF, TGF-alpha and EGFR expression in human preimplantation embryos. Development, 1995. 121(2): p. 299-307.

282. Thongkittidilok, C., et al., Epidermal growth factor improves developmental competence and embryonic quality of singly cultured domestic cat embryos. J Reprod Dev, 2015. 61(4): p. 269-76. 
283. Watson, A.J., et al., Expression of growth factor ligand and receptor genes in the preimplantation bovine embryo. Mol Reprod Dev, 1992. 31(2): p. 87-95.

284. Watson, A.J., et al., A growth factor phenotype map for ovine preimplantation development. Biol Reprod, 1994. 50(4): p. 725-33.

285. Wei, Z., et al., Effect of epidermal growth factor on preimplantation development and its receptor expression in porcine embryos. Mol Reprod Dev, 2001. 60(4): p. 457-62.

286. Wiley, L.M., et al., Epidermal growth factor receptor $m R N A$ and protein increase after the four-cell preimplantation stage in murine development. Dev Biol, 1992. 149(2): p. 247-60.

287. Sibilia, M. and E.F. Wagner, Strain-dependent epithelial defects in mice lacking the EGF receptor. Science, 1995. 269(5221): p. 234-8.

288. Koshibu, K. and P. Levitt, Sex differences in expression of transforming growth factor-alpha and epidermal growth factor receptor mRNA in Waved-1 and C57BI6 mice. Neuroscience, 2005. 134(3): p. 877-87.

289. Luetteke, N.C., et al., The mouse waved-2 phenotype results from a point mutation in the EGF receptor tyrosine kinase. Genes Dev, 1994. 8(4): p. 399413.

290. Ceresa, B.P. and S.L. Schmid, Regulation of signal transduction by endocytosis. Curr Opin Cell Biol, 2000. 12(2): p. 204-10.

291. Grabe, M. and G. Oster, Regulation of organelle acidity. J Gen Physiol, 2001. 117(4): p. 329-44.

292. Levkowitz, G., et al., c-Cbl/Sli-1 regulates endocytic sorting and ubiquitination of the epidermal growth factor receptor. Genes Dev, 1998. 12(23): p. 3663-74.

293. Levkowitz, G., et al., Ubiquitin ligase activity and tyrosine phosphorylation underlie suppression of growth factor signaling by c-Cbl/Sli-1. Mol Cell, 1999. 4(6): p. 1029-40.

294. Umebayashi, K., H. Stenmark, and T. Yoshimori, Ubc4/5 and c-Cbl continue to ubiquitinate EGF receptor after internalization to facilitate polyubiquitination and degradation. Mol Biol Cell, 2008. 19(8): p. 3454-62.

295. Wiley, H.S., et al., The role of tyrosine kinase activity in endocytosis, compartmentation, and down-regulation of the epidermal growth factor receptor. J Biol Chem, 1991. 266(17): p. 11083-94.

296. McClintock, J.L. and B.P. Ceresa, Transforming growth factor-\{alpha\} enhances corneal epithelial cell migration by promoting EGFR recycling. Invest Ophthalmol Vis Sci, 2010. 51(7): p. 3455-61.

297. Thoresen, G.H., et al., Response to transforming growth factor alpha (TGFalpha) and epidermal growth factor (EGF) in hepatocytes: lower EGF receptor affinity of TGFalpha is associated with more sustained activation of p42/p44 mitogenactivated protein kinase and greater efficacy in stimulation of DNA synthesis. J Cell Physiol, 1998. 175(1): p. 10-8.

298. Rutten, M.J., et al., Identification of an EGF/TGF-alpha receptor in primary cultures of guinea pig gastric mucous epithelial cells. Am J Physiol, 1996. 270(4 Pt 1): p. G604-12.

299. Gruenberg, J. and F.R. Maxfield, Membrane transport in the endocytic pathway. Curr Opin Cell Biol, 1995. 7(4): p. 552-63.

300. Ebner, R. and R. Derynck, Epidermal growth factor and transforming growth factor-alpha: differential intracellular routing and processing of ligand-receptor complexes. Cell Regul, 1991. 2(8): p. 599-612.

301. Haslekas, C., et al., The inhibitory effect of ErbB2 on epidermal growth factorinduced formation of clathrin-coated pits correlates with retention of epidermal 
growth factor receptor-ErbB2 oligomeric complexes at the plasma membrane. Mol Biol Cell, 2005. 16(12): p. 5832-42.

302. Lenferink, A.E., et al., Differential endocytic routing of homo- and hetero-dimeric ErbB tyrosine kinases confers signaling superiority to receptor heterodimers. EMBO J, 1998. 17(12): p. 3385-97.

303. Offterdinger, M. and P.I. Bastiaens, Prolonged EGFR signaling by ERBB2mediated sequestration at the plasma membrane. Traffic, 2008. 9(1): p. 147-55.

304. Veale, D., et al., Epidermal growth factor receptors in non-small cell lung cancer. Br J Cancer, 1987. 55(5): p. 513-6.

305. Rusch, V., et al., Overexpression of the epidermal growth factor receptor and its ligand transforming growth factor alpha is frequent in resectable non-small cell lung cancer but does not predict tumor progression. Clin Cancer Res, 1997. 3(4): p. 515-22.

306. Sridhar, S.S., L. Seymour, and F.A. Shepherd, Inhibitors of epidermal-growthfactor receptors: a review of clinical research with a focus on non-small-cell lung cancer. Lancet Oncol, 2003. 4(7): p. 397-406.

307. Hirsch, F.R., M. Varella-Garcia, and F. Cappuzzo, Predictive value of EGFR and HER2 overexpression in advanced non-small-cell lung cancer. Oncogene, 2009. 28 Suppl 1: p. S32-7.

308. Merrick, D.T., et al., Analysis of c-ErbB1/epidermal growth factor receptor and cErbB2/HER-2 expression in bronchial dysplasia: evaluation of potential targets for chemoprevention of lung cancer. Clin Cancer Res, 2006. 12(7 Pt 1): p. 22818.

309. Selvaggi, G., et al., Epidermal growth factor receptor overexpression correlates with a poor prognosis in completely resected non-small-cell lung cancer. Ann Oncol, 2004. 15(1): p. 28-32.

310. Nakamura, H., et al., Survival impact of epidermal growth factor receptor overexpression in patients with non-small cell lung cancer: a meta-analysis. Thorax, 2006. 61(2): p. 140-5.

311. Wong, A.J., et al., Increased expression of the epidermal growth factor receptor gene in malignant gliomas is invariably associated with gene amplification. Proc Natl Acad Sci U S A, 1987. 84(19): p. 6899-903.

312. Mesbahi, Y., et al., Targeting of EGFR increase anti-cancer effects of arsenic trioxide: Promising treatment for glioblastoma multiform. Eur J Pharmacol, 2018. 820: p. 274-285.

313. Hatanpaa, K.J., et al., Epidermal growth factor receptor in glioma: signal transduction, neuropathology, imaging, and radioresistance. Neoplasia, 2010. 12(9): p. 675-84.

314. Xu, H., et al., Epidermal growth factor receptor in glioblastoma. Oncol Lett, 2017. 14(1): p. 512-516.

315. Westphal, M., C.L. Maire, and K. Lamszus, EGFR as a Target for Glioblastoma Treatment: An Unfulfilled Promise. CNS Drugs, 2017. 31(9): p. 723-735.

316. Senhaji, N., et al., EGFR Amplification and IDH Mutations in Glioblastoma Patients of the Northeast of Morocco. Biomed Res Int, 2017. 2017: p. 8045859.

317. Normanno, N., et al., The role of EGF-related peptides in tumor growth. Front Biosci, 2001. 6: p. D685-707.

318. Revillion, F., et al., ErbB/HER ligands in human breast cancer, and relationships with their receptors, the bio-pathological features and prognosis. Ann Oncol, 2008. 19(1): p. 73-80.

319. Vaughan, T.J., et al., Molecular cloning and tissue distribution of pig transforming growth factor alpha. Biochem J, 1993. 296 ( Pt 3): p. 837-42. 
320. Seno, M., et al., Human betacellulin, a member of the EGF family dominantly expressed in pancreas and small intestine, is fully active in a monomeric form. Growth Factors, 1996. 13(3-4): p. 181-91.

321. Toyoda, H., et al., Distribution of mRNA for human epiregulin, a differentially expressed member of the epidermal growth factor family. Biochem J, 1997. 326 ( Pt 1): p. 69-75.

322. Jacobs, B., et al., Amphiregulin and epiregulin mRNA expression in primary tumors predicts outcome in metastatic colorectal cancer treated with cetuximab. J Clin Oncol, 2009. 27(30): p. 5068-74.

323. Roepstorff, K., et al., Differential effects of EGFR ligands on endocytic sorting of the receptor. Traffic, 2009. 10(8): p. 1115-27.

324. Gao, M., et al., SPRY2 loss enhances ErbB trafficking and PI3K/AKT signalling to drive human and mouse prostate carcinogenesis. EMBO Mol Med, 2012. 4(8): p. 776-90.

325. Roepstorff, K., et al., Endocytic downregulation of ErbB receptors: mechanisms and relevance in cancer. Histochem Cell Biol, 2008. 129(5): p. 563-78.

326. Shtiegman, K., et al., Defective ubiquitinylation of EGFR mutants of lung cancer confers prolonged signaling. Oncogene, 2007. 26(49): p. 6968-78.

327. Sorkin, A. and M. von Zastrow, Endocytosis and signalling: intertwining molecular networks. Nat Rev Mol Cell Biol, 2009. 10(9): p. 609-22.

328. Thalappilly, S., et al., VAV2 regulates epidermal growth factor receptor endocytosis and degradation. Oncogene, 2010. 29(17): p. 2528-39.

329. Tomas, A., C.E. Futter, and E.R. Eden, EGF receptor trafficking: consequences for signaling and cancer. Trends Cell Biol, 2014. 24(1): p. 26-34.

330. Winograd-Katz, S.E. and A. Levitzki, Cisplatin induces PKB/Akt activation and p38(MAPK) phosphorylation of the EGF receptor. Oncogene, 2006. 25(56): $p$. 7381-90.

331. Zwang, Y. and Y. Yarden, p38 MAP kinase mediates stress-induced internalization of EGFR: implications for cancer chemotherapy. EMBO J, 2006. 25(18): p. 4195-206.

332. Herbst, J.J., et al., Regulation of postendocytic trafficking of the epidermal growth factor receptor through endosomal retention. J Biol Chem, 1994. 269(17): p. 12865-73.

333. Wang, Y., et al., Endosomal signaling of epidermal growth factor receptor stimulates signal transduction pathways leading to cell survival. Mol Cell Biol, 2002. 22(20): p. 7279-90.

334. Mosesson, Y., G.B. Mills, and Y. Yarden, Derailed endocytosis: an emerging feature of cancer. Nat Rev Cancer, 2008. 8(11): p. 835-50.

335. Masui, H., et al., Enhanced tumorigenesis of NR6 cells which express non-downregulating epidermal growth factor receptors. Cancer Res, 1991. 51(22): p. 61705 .

336. Irmer, D., J.O. Funk, and A. Blaukat, EGFR kinase domain mutations - functional impact and relevance for lung cancer therapy. Oncogene, 2007. 26(39): p. 5693701.

337. Nishikawa, R., et al., A mutant epidermal growth factor receptor common in human glioma confers enhanced tumorigenicity. Proc Natl Acad Sci U S A, 1994. 91(16): p. 7727-31.

338. Batra, S.K., et al., Epidermal growth factor ligand-independent, unregulated, celltransforming potential of a naturally occurring human mutant EGFRvIll gene. Cell Growth Differ, 1995. 6(10): p. 1251-9. 
339. Reist, C.J., et al., Tumor-specific anti-epidermal growth factor receptor variant III monoclonal antibodies: use of the tyramine-cellobiose radioiodination method enhances cellular retention and uptake in tumor xenografts. Cancer Res, 1995. 55(19): p. 4375-82.

340. Huang, H.S., et al., The enhanced tumorigenic activity of a mutant epidermal growth factor receptor common in human cancers is mediated by threshold levels of constitutive tyrosine phosphorylation and unattenuated signaling. J Biol Chem, 1997. 272(5): p. 2927-35.

341. Bigner, S.H., et al., Characterization of the epidermal growth factor receptor in human glioma cell lines and xenografts. Cancer Res, 1990. 50(24): p. 8017-22.

342. Wikstrand, C.J., et al., Monoclonal antibodies against EGFRvIll are tumor specific and react with breast and lung carcinomas and malignant gliomas. Cancer Res, 1995. 55(14): p. 3140-8.

343. Moscatello, D.K., et al., Frequent expression of a mutant epidermal growth factor receptor in multiple human tumors. Cancer Res, 1995. 55(23): p. 5536-9.

344. Ji, H., N.E. Sharpless, and K.K. Wong, EGFR targeted therapy: view from biological standpoint. Cell Cycle, 2006. 5(18): p. 2072-6.

345. Pao, W. and V.A. Miller, Epidermal growth factor receptor mutations, smallmolecule kinase inhibitors, and non-small-cell lung cancer: current knowledge and future directions. J Clin Oncol, 2005. 23(11): p. 2556-68.

346. Yun, C.H., et al., Structures of lung cancer-derived EGFR mutants and inhibitor complexes: mechanism of activation and insights into differential inhibitor sensitivity. Cancer Cell, 2007. 11(3): p. 217-27.

347. Zhang, X., et al., An allosteric mechanism for activation of the kinase domain of epidermal growth factor receptor. Cell, 2006. 125(6): p. 1137-49.

348. Paez, J.G., et al., EGFR mutations in lung cancer: correlation with clinical response to gefitinib therapy. Science, 2004. 304(5676): p. 1497-500.

349. Lynch, T.J., et al., Activating mutations in the epidermal growth factor receptor underlying responsiveness of non-small-cell lung cancer to gefitinib. $\mathrm{N}$ Engl $\mathrm{J}$ Med, 2004. 350(21): p. 2129-39.

350. Yun, C.H., et al., The T790M mutation in EGFR kinase causes drug resistance by increasing the affinity for ATP. Proc Natl Acad Sci U S A, 2008. 105(6): p. 2070-5.

351. Morgillo, F., et al., Mechanisms of resistance to EGFR-targeted drugs: lung cancer. ESMO Open, 2016. 1(3): p. e000060.

352. Jorge, S.E., S.S. Kobayashi, and D.B. Costa, Epidermal growth factor receptor (EGFR) mutations in lung cancer: preclinical and clinical data. Braz J Med Biol Res, 2014. 47(11): p. 929-39.

353. Pao, W., et al., EGF receptor gene mutations are common in lung cancers from "never smokers" and are associated with sensitivity of tumors to gefitinib and erlotinib. Proc Natl Acad Sci U S A, 2004. 101(36): p. 13306-11.

354. Carey, K.D., et al., Kinetic analysis of epidermal growth factor receptor somatic mutant proteins shows increased sensitivity to the epidermal growth factor receptor tyrosine kinase inhibitor, erlotinib. Cancer Res, 2006. 66(16): p. 816371.

355. Chen, Y.R., et al., Distinctive activation patterns in constitutively active and gefitinib-sensitive EGFR mutants. Oncogene, 2006. 25(8): p. 1205-15.

356. Sordella, R., et al., Gefitinib-sensitizing EGFR mutations in lung cancer activate anti-apoptotic pathways. Science, 2004. 305(5687): p. 1163-7.

357. Shimamura, T., et al., Non-small-cell lung cancer and Ba/F3 transformed cells harboring the ERBB2 G776insV_G/C mutation are sensitive to the dual-specific 
epidermal growth factor receptor and ERBB2 inhibitor HKI-272. Cancer Res, 2006. 66(13): p. 6487-91.

358. Schrevel, M., et al., Autocrine expression of the epidermal growth factor receptor ligand heparin-binding EGF-like growth factor in cervical cancer. Int J Oncol, 2017. 50(6): p. 1947-1954.

359. Iwamoto, R., et al., Characterization of a Novel Anti-Human HB-EGF Monoclonal Antibody Applicable for Paraffin-Embedded Tissues and Diagnosis of HB-EGF-

Related Cancers. Monoclon Antib Immunodiagn Immunother, 2016. 35(2): p. 7382.

360. Zhou, Z.N., et al., Autocrine HBEGF expression promotes breast cancer intravasation, metastasis and macrophage-independent invasion in vivo. Oncogene, 2014. 33(29): p. 3784-93.

361. Byeon, S.J., et al., Expression of the ERBB Family of Ligands and Receptors in Gastric Cancer. Pathobiology, 2017. 84(4): p. 210-217.

362. Kawasaki, H., et al., Regulation of intestinal myofibroblasts by KRas-mutated colorectal cancer cells through heparin-binding epidermal growth factor-like growth factor. Oncol Rep, 2017. 37(5): p. 3128-3136.

363. Germolec, D.R., et al., Arsenic enhancement of skin neoplasia by chronic stimulation of growth factors. Am J Pathol, 1998. 153(6): p. 1775-85.

364. Lantz, R.C. and A.M. Hays, Role of oxidative stress in arsenic-induced toxicity. Drug Metab Rev, 2006. 38(4): p. 791-804.

365. Sigismund, S., et al., Clathrin-independent endocytosis of ubiquitinated cargos. Proc Natl Acad Sci U S A, 2005. 102(8): p. 2760-5.

366. Sigismund, S., et al., Clathrin-mediated internalization is essential for sustained EGFR signaling but dispensable for degradation. Dev Cell, 2008. 15(2): p. 20919.

367. Zhao, Y., P. Toselli, and W. Li, Microtubules as a critical target for arsenic toxicity in lung cells in vitro and in vivo. Int J Environ Res Public Health, 2012. 9(2): p. 474-95.

368. Burkhardt, J.K., The role of microtubule-based motor proteins in maintaining the structure and function of the Golgi complex. Biochim Biophys Acta, 1998. 1404(1-2): p. 113-26.

369. Pareja, F., et al., Deubiquitination of EGFR by Cezanne-1 contributes to cancer progression. Oncogene, 2012. 31(43): p. 4599-608.

370. Sanders, A.P., et al., Arsenic in North Carolina: public health implications. Environ Int, 2012. 38(1): p. 10-6.

371. Brown, E., C.G. Yedjou, and P.B. Tchounwou, Cytotoxicity and oxidative stress in human liver carcinoma cells exposed to arsenic trioxide (HepG(2)). Met lons Biol Med, 2008. 10: p. 583-587.

372. Flora, S.J., Arsenic-induced oxidative stress and its reversibility. Free Radic Biol Med, 2011. 51(2): p. 257-81.

373. Chen, F., et al., Opposite effect of NF-kappa B and c-Jun N-terminal kinase on p53-independent GADD45 induction by arsenite. J Biol Chem, 2001. 276(14): p. 11414-9.

374. Zhang, Y., et al., Nucleolin links to arsenic-induced stabilization of GADD45alpha $m R N A$. Nucleic Acids Res, 2006. 34(2): p. 485-95.

375. Andrew, A.S., et al., Exposure to arsenic at levels found inU.S. drinking water modifies expression in the mouse lung. Toxicol Sci, 2007. 100(1): p. 75-87.

376. Cardoso, A.P.F., L. Al-Eryani, and J.C. States, Arsenic-induced carcinogenesis: the impact of miRNA dysregulation. Toxicol Sci, 2018. 
377. Pratheeshkumar, P., et al., Oncogenic transformation of human lung bronchial epithelial cells induced by arsenic involves ROS-dependent activation of STAT3miR-21-PDCD4 mechanism. Sci Rep, 2016. 6: p. 37227.

378. Michailidi, C., et al., Involvement of epigenetics and EMT-related miRNA in arsenic-induced neoplastic transformation and their potential clinical use. Cancer Prev Res (Phila), 2015. 8(3): p. 208-21.

379. Ren, X., et al., Arsenic responsive microRNAs in vivo and their potential involvement in arsenic-induced oxidative stress. Toxicol Appl Pharmacol, 2015. 283(3): p. 198-209.

380. Reddel, R.R., et al., Transformation of human bronchial epithelial cells by infection with SV40 or adenovirus-12 SV40 hybrid virus, or transfection via strontium phosphate coprecipitation with a plasmid containing SV40 early region genes. Cancer Res, 1988. 48(7): p. 1904-9.

381. Zhao, F., et al., Arsenite-induced pseudo-hypoxia results in loss of anchoragedependent growth in BEAS-2B pulmonary epithelial cells. PLoS One, 2014. 9(12): p. e114549.

382. Park, Y.H., et al., Human bronchial epithelial BEAS-2B cells, an appropriate in vitro model to study heavy metals induced carcinogenesis. Toxicol Appl Pharmacol, 2015. 287(3): p. 240-5.

383. Sun, H., et al., Comparison of gene expression profiles in chromate transformed BEAS-2B cells. PLoS One, 2011. 6(3): p. e17982.

384. O'Hara, K.A., et al., Cr(VI)-stimulated STAT3 tyrosine phosphorylation and nuclear translocation in human airway epithelial cells requires Lck. Biochem J, 2007. 402(2): p. 261-9.

385. Cai, T., et al., A cross-talk between NFAT and NF-kappaB pathways is crucial for nickel-induced COX-2 expression in Beas-2B cells. Curr Cancer Drug Targets, 2011. 11(5): p. 548-59.

386. Vahter, M., Health effects of early life exposure to arsenic. Basic Clin Pharmacol Toxicol, 2008. 102(2): p. 204-11.

387. Wang, D., et al., High expression of EGFR predicts poor survival in patients with resected T3 stage gastric adenocarcinoma and promotes cancer cell survival. Oncol Lett, 2017. 13(5): p. 3003-3013.

388. Tang, Y., et al., Overexpression of epithelial growth factor receptor (EGFR) predicts better response to neo-adjuvant chemotherapy in patients with triplenegative breast cancer. J Transl Med, 2012. 10 Suppl 1: p. S4.

389. Jiang, D., et al., The prognostic value of EGFR overexpression and amplification in Esophageal squamous cell Carcinoma. BMC Cancer, 2015. 15: p. 377.

390. Chung, C.H., et al., Increased epidermal growth factor receptor gene copy number is associated with poor prognosis in head and neck squamous cell carcinomas. J Clin Oncol, 2006. 24(25): p. 4170-6.

391. Martinazzi, M., et al., Epidermal growth factor receptor immunohistochemistry in different histological types of infiltrating breast carcinoma. J Clin Pathol, 1993. 46(11): p. 1009-10.

392. Ang, K.K., et al., Impact of epidermal growth factor receptor expression on survival and pattern of relapse in patients with advanced head and neck carcinoma. Cancer Res, 2002. 62(24): p. 7350-6.

393. Temam, S., et al., Epidermal growth factor receptor copy number alterations correlate with poor clinical outcome in patients with head and neck squamous cancer. J Clin Oncol, 2007. 25(16): p. 2164-70. 
394. Volm, M., W. Rittgen, and P. Drings, Prognostic value of ERBB-1, VEGF, cyclin $A, F O S, J U N$ and MYC in patients with squamous cell lung carcinomas. $\mathrm{Br} \mathrm{J}$ Cancer, 1998. 77(4): p. 663-9.

395. Ohsaki, Y., et al., Epidermal growth factor receptor expression correlates with poor prognosis in non-small cell lung cancer patients with p53 overexpression. Oncol Rep, 2000. 7(3): p. 603-7.

396. Ceresa, B.P. and J.L. Peterson, Cell and molecular biology of epidermal growth factor receptor. Int Rev Cell Mol Biol, 2014. 313: p. 145-78.

397. Qian, X., et al., Heterodimerization of epidermal growth factor receptor and wildtype or kinase-deficient Neu: a mechanism of interreceptor kinase activation and transphosphorylation. Proc Natl Acad Sci U S A, 1994. 91(4): p. 1500-4.

398. Ogiso, H., et al., Crystal structure of the complex of human epidermal growth factor and receptor extracellular domains. Cell, 2002. 110(6): p. 775-87.

399. Schneider, C.A., W.S. Rasband, and K.W. Eliceiri, NIH Image to ImageJ: 25 years of image analysis. Nat Methods, 2012. 9(7): p. 671-5.

400. Patterson, T.J. and R.H. Rice, Arsenite and insulin exhibit opposing effects on epidermal growth factor receptor and keratinocyte proliferative potential. Toxicol Appl Pharmacol, 2007. 221(1): p. 119-28.

401. Eblin, K.E., et al., Mitogenic signal transduction caused by monomethylarsonous acid in human bladder cells: role in arsenic-induced carcinogenesis. Toxicol Sci, 2007. 95(2): p. 321-30.

402. Bryhn, A.C. and P.H. Dimberg, An operational definition of a statistically meaningful trend. PLoS One, 2011. 6(4): p. e19241.

403. Valenzuela, O.L., et al., Chronic arsenic exposure increases TGFalpha concentration in bladder urothelial cells of Mexican populations environmentally exposed to inorganic arsenic. Toxicol Appl Pharmacol, 2007. 222(3): p. 264-70.

404. Moriai, T., et al., A variant epidermal growth factor receptor exhibits altered type alpha transforming growth factor binding and transmembrane signaling. Proc Natl Acad Sci U S A, 1994. 91(21): p. 10217-21.

405. Di Marco, E., et al., Autocrine interaction between TGF alpha and the EGFreceptor: quantitative requirements for induction of the malignant phenotype. Oncogene, 1989. 4(7): p. 831-8.

406. Baselga, J., et al., Autocrine regulation of membrane transforming growth factoralpha cleavage. J Biol Chem, 1996. 271(6): p. 3279-84.

407. Stromberg, K., et al., Transforming growth factor-alpha acts as an autocrine growth factor in ovarian carcinoma cell lines. Cancer Res, 1992. 52(2): p. 341-7.

408. Morocz, I.A., et al., Autocrine stimulation of a human lung mesothelioma cell line is mediated through the transforming growth factor alpha/epidermal growth factor receptor mitogenic pathway. Br J Cancer, 1994. 70(5): p. 850-6.

409. Smith, J.J., R. Derynck, and M. Korc, Production of transforming growth factor alpha in human pancreatic cancer cells: evidence for a superagonist autocrine cycle. Proc Natl Acad Sci U S A, 1987. 84(21): p. 7567-70.

410. Putnam, E.A., et al., Autocrine growth stimulation by transforming growth factoralpha in human non-small cell lung cancer. Surg Oncol, 1992. 1(1): p. 49-60.

411. Ruck, A. and S. Paulie, EGF, TGF alpha, AR and HB-EGF are autocrine growth factors for human bladder carcinoma cell lines. Anticancer Res, 1998. 18(3A): p. 1447-52.

412. Ngalame, N.N.O., et al., Arsenic Alters Exosome Quantity and Cargo to Mediate Stem Cell Recruitment Into a Cancer Stem Cell-Like Phenotype. Toxicol Sci, 2018. 165(1): p. 40-49. 
413. Lokuge, K.M., et al., The effect of arsenic mitigation interventions on disease burden in Bangladesh. Environ Health Perspect, 2004. 112(11): p. 1172-7.

414. Petrie, R.J., A.D. Doyle, and K.M. Yamada, Random versus directionally persistent cell migration. Nat Rev Mol Cell Biol, 2009. 10(8): p. 538-49.

415. Gagliardi, P.A., et al., Real-time monitoring of cell protrusion dynamics by impedance responses. Sci Rep, 2015. 5: p. 10206.

416. Heck, T., et al., The role of actin protrusion dynamics in cell migration through a degradable viscoelastic extracellular matrix: Insights from a computational model. PLoS Comput Biol, 2020. 16(1): p. e1007250.

417. Diao, W., et al., Behaviors of Glioblastoma Cells in in Vitro Microenvironments. Sci Rep, 2019. 9(1): p. 85.

418. Muscarella, A.M., et al., Unique cellular protrusions mediate breast cancer cell migration by tethering to osteogenic cells. NPJ Breast Cancer, 2020. 6: p. 42.

419. Miyazaki, K., et al., Cancer cell migration on elongate protrusions of fibroblasts in collagen matrix. Sci Rep, 2019. 9(1): p. 292.

420. Yang, D., et al., Axon-like protrusions promote small cell lung cancer migration and metastasis. Elife, 2019. 8.

421. Yamaguchi, H. and J. Condeelis, Regulation of the actin cytoskeleton in cancer cell migration and invasion. Biochim Biophys Acta, 2007. 1773(5): p. 642-52.

422. Bravo-Cordero, J.J., L. Hodgson, and J.S. Condeelis, Spatial regulation of tumor cell protrusions by RhoC. Cell Adh Migr, 2014. 8(3): p. 263-7.

423. Weiger, M.C., et al., Real-time motion analysis reveals cell directionality as an indicator of breast cancer progression. PLoS One, 2013. 8(3): p. e58859.

424. Nayak, R.C., et al., Rho GTPases control specific cytoskeleton-dependent functions of hematopoietic stem cells. Immunol Rev, 2013. 256(1): p. 255-68.

425. Haga, R.B. and A.J. Ridley, Rho GTPases: Regulation and roles in cancer cell biology. Small GTPases, 2016. 7(4): p. 207-221.

426. de Curtis, I. and J. Meldolesi, Cell surface dynamics - how Rho GTPases orchestrate the interplay between the plasma membrane and the cortical cytoskeleton. J Cell Sci, 2012. 125(Pt 19): p. 4435-44.

427. Sit, S.T. and E. Manser, Rho GTPases and their role in organizing the actin cytoskeleton. J Cell Sci, 2011. 124(Pt 5): p. 679-83.

428. An, Y., et al., Rac1 and Cdc42 Play Important Roles in Arsenic Neurotoxicity in Primary Cultured Rat Cerebellar Astrocytes. Biol Trace Elem Res, 2016. 170(1): p. 173-82.

429. Stupack, D.G., Integrins as a distinct subtype of dependence receptors. Cell Death Differ, 2005. 12(8): p. 1021-30.

430. $\mathrm{Li}, \mathrm{J}$. and T.A. Springer, Integrin extension enables ultrasensitive regulation by cytoskeletal force. Proc Natl Acad Sci U S A, 2017. 114(18): p. 4685-4690.

431. Missirlis, D., et al., Substrate engagement of integrins alpha5beta1 and alphavbeta3 is necessary, but not sufficient, for high directional persistence in migration on fibronectin. Sci Rep, 2016. 6: p. 23258.

432. Malm, S.W., E.A. Amouzougan, and W.T. Klimecki, Fetal bovine serum induces sustained, but reversible, epithelial-mesenchymal transition in the BEAS-2B cell line. Toxicol In Vitro, 2018. 50: p. 383-390.

433. Zhao, F. and W.T. Klimecki, Culture conditions profoundly impact phenotype in BEAS-2B, a human pulmonary epithelial model. J Appl Toxicol, 2015. 35(8): p. 945-51.

434. Laine, J.E., et al., Maternal arsenic exposure, arsenic methylation efficiency, and birth outcomes in the Biomarkers of Exposure to ARsenic (BEAR) pregnancy cohort in Mexico. Environ Health Perspect, 2015. 123(2): p. 186-92. 
435. Hsueh, Y.M., et al., Association of Arsenic Methylation Capacity with Developmental Delays and Health Status in Children: A Prospective CaseControl Trial. Sci Rep, 2016. 6: p. 37287.

436. Navasumrit, P., et al., Exposure to arsenic in utero is associated with various types of DNA damage and micronuclei in newborns: a birth cohort study. Environ Health, 2019. 18(1): p. 51.

437. Vahter, M., Mechanisms of arsenic biotransformation. Toxicology, 2002. 181182: p. 211-7.

438. Vahter, M., Effects of arsenic on maternal and fetal health. Annu Rev Nutr, 2009. 29: p. 381-99.

439. Fei, D.L., et al., Association between In Utero arsenic exposure, placental gene expression, and infant birth weight: a US birth cohort study. Environ Health, 2013. 12: p. 58. 


\section{CURRICULUM VITAE \\ Christine Kim \\ 3250 Autumn Ridge Ct. Apt. 4 Jeffersonville, IN 47130 c0kim007@louisville.edu·765-409-1094}

\section{EDUCATION}

- University of Louisville, Louisville, KY

Fall 2016- present

Ph.D. Program in Pharmacology \& Toxicology

- University of Kentucky, Lexington, KY

Fall 2012- June 2015

M.S. Program in Toxicology

- Purdue University, West Lafayette, IN

Fall 2007- May 2011

Bachelors of Science in Biology

Minor in Japanese

\section{HONORS \& AWARDS}

- Academic Pediatric Association Environmental Health Scholars Retreat Travel Award

- OVSOT $2^{\text {nd }}$ place PhD Poster Award

November 1-3, 2019

- KTAA Best Presentation Award (Society of Toxicology)

October 2019

March 2019

- $10^{\text {th }}$ Conference on Metal Toxicity and Carcinogenesis Travel Award October 2018

- Pre-doctoral trainee on National Institute of Health Sciences-funded Training Program in Environmental Health Sciences (T32-ES011564) October 2018-February 2021

- ASBMB 2014 Graduate/Postdoctoral Travel Award fund

April 2014

- Jeffery Tobacco Fellowship

April 2014

- Semester Honors and Dean's List, Purdue University

Spring 2009-May 2011

\section{PRESENTATIONS}

1. Oral Presentation- $16^{\text {th }}$ APA ENvironmetanl Health Scholars Retreat

November 1-3, 2019

2. Poster Presentation- Ohio Valley Society of Toxicology (OVSOT) October 18, 2019

3. Oral Presentation- UK Society of Postdoctoral Scholars (SOPS) Symposium

May 31, 2019

4. Poster Presentation- Soceity of Toxicology (SOT)

March 10-14, 2019

5. Poster Presentation- Ohio Valley Society of Toxicology (OVSOT) November 30, 2018

6. Poster Presentation- $10^{\text {th }}$ Conference on Metal Toxicity and Carcinogenesis

October 28-31, 2018

7. Poster Presentation- Research!Louisville

October 8-12, 2018

8. Poster Presentation- Ohio Valley Society of Toxicology (OVSOT) December 1, 2017

9. Poster Presentation- Research!Louisville September 11-15, 2017

RESEARCH EXPERIENCE

University of Louisville, Louisville, KY

August 2016-present

Graduate Fellow

- EGFR dependency in arsenic-induced transformation of non-malignant human 
bronchial epithelial cells.

- Arsenic regulation the synthesis of ErbB receptors and their ligands.

- EGFR trafficking in arsenic-transformed cells.

University of Kentucky, Lexington, KY

August 2012-June 2015

Graduate Fellow

- Histone modification of H3K36 by cigarette smoking condensate.

- The impact of cigarette smoking condensate on chromatin assembly by histone modification.

Purdue University, West Lafayette, IN

Summer 2009-May 2011

Laboratory Technician

- Investigate activated Cdc42 kinase regulation on Dock localization in male germ cells during Drosophila spermatogenesis.

GRANTS/FELLOWSHIPS

T32-ES011564 (NIH)

Project Period: October, 2018-February 2021

\section{PUBLICATIONS}

- Kim, C., Chen, J., Ceresa, BP (2021) Chronic arsenic increases EGFR-dependent cell motility in BEAS-2B cells. Tox In Vitro. Under Review

- Kim, C. and Ceresa, BP. (2020) Using in vitro models to dissect the molecular effects of arsenic exposure in skin and lung cancer. Applied In Vitro Tox. Under Review

- Kim, C., States, JC., Ceresa, BP. (2020) Chronic and acute arsenic exposure enhance EGFR expression via distinct molecular mechanisms. Tox In Vitro. PMID: 32599262

- Tong, D., Ortega, J., Kim, C., Huang, J., Gu, L., Li, GM. (2015) Arsenic inhibits DNA mismatch repair by promoting EGFR expression and PCNA phosphorylation.

J.Biol.Chem. PMID: 25907674

- Abdallah, A.M., Zhou, X., Kim, C., Shah, K.K., Hogden, C., Schoenherr, J.A., Clemen, J.C., Chang, H.C. (2013) Activated Cdc42 kinase regulates Dock localization in male germ cells during Drosophila spermatogenesis. Dev. Biol. 378, 141-153. PMID: 23562806 